\begin{tabular}{|l|l|}
\hline $\begin{array}{l}\text { 2. To: (Receiving Organization) } \\
\text { Distribution }\end{array}$ & $\begin{array}{l}\text { 3. From: (Originating Organization) } \\
\text { I.S. Engineering }\end{array}$ \\
\hline $\begin{array}{l}\text { 5. Proj./Prog./Dept./Div.: } \\
\text { SST Interim Stabilization }\end{array}$ & $\begin{array}{l}\text { 6. Design Authority/Design Agent/Cog. Engr.: } \\
\text { D.K. DeFord }\end{array}$ \\
\hline
\end{tabular}

8. Originator Remarks:

REMOVAL OF SEPARABLE ORGANIC FROM TANK 241-C-103 SCOPING STUDY
4. Related EDT No.:

$\mathrm{N} / \mathrm{A}$

7. Purchase Order No.:

$\mathrm{N} / \mathrm{A}$

9. Equip./Component No.:

$\mathrm{N} / \mathrm{A}$

10. System/Bldg./Facility:

241-C-103

12. Major Assm. Dwg. No.:

$\mathrm{N} / \mathrm{A}$

13. Permit/Permit Application No:

N/A

14. Required Response Date: $\mathrm{N} / \mathrm{A}$

15.

\begin{tabular}{|c|c|}
\hline $\begin{array}{c}\text { (A) } \\
\text { liem } \\
\text { No. }\end{array}$ & (B) Document/Drawing No. \\
\hline 1 & RPP -6310 \\
\hline & \\
\hline & \\
\hline & \\
\hline & \\
\hline & \\
\hline & \\
\hline
\end{tabular}

16.

Approval Designator $(F)$

E, S, Q, D OR N/A (See WHC-CM-3-5, Sec. 12.7)

17.

\begin{tabular}{|c|c|c|}
\hline $\begin{array}{l}\text { (G) } \\
\text { Rea- } \\
\text { son }\end{array}$ & $\begin{array}{c}(\mathrm{H}) \\
\text { Disp. }\end{array}$ & (K) Signature \\
\hline & & Design Authority $\mathrm{N} / \mathrm{A}$ \\
\hline & & Design Agent $\quad \mathrm{N} / \mathrm{A}$ \\
\hline 1 & 1 & Cog. Eng. DK DEFORD \&. Detd $5 / 9 / 00 \quad 57-24$ \\
\hline 1. & 1 & Cog. Mgr. MR KOCH थ/fhdR kl 5/9/00 S7-24 \\
\hline & & QA $\quad N / A$ \\
\hline & & Safety \\
\hline & & Env. \\
\hline
\end{tabular}

\begin{tabular}{|c|c|c|}
\hline $\begin{array}{l}\text { \&. Pl } \\
\text { D.K. DEFORD }\end{array}$ & $5 / 9 / 00$ & $\mathrm{~N} / \mathrm{A}$ \\
\hline $\begin{array}{l}\text { Signature of EDT } \\
\text { Originator }\end{array}$ & Date & $\begin{array}{l}\text { Authorized Regresentative } \\
\text { for Receiving Organization }\end{array}$ \\
\hline
\end{tabular}

20.

\begin{tabular}{|c|c|}
\hline $\begin{array}{l}\text { morethlo } \\
\text { M.R. KOCH }\end{array}$ & $5 / 9 / 00$ \\
\hline $\begin{array}{l}\text { Design Authority } \\
\text { Cognizant Manager }\end{array}$ & Date \\
\hline
\end{tabular}

KEY

\begin{tabular}{|l|l|l|}
$\begin{array}{c}\text { (C) Sheet } \\
\text { No. }\end{array}$ & $\begin{array}{c}\text { (D) Rev. } \\
\text { No. }\end{array}$ & (E) Title or Description of Data Transmitted \\
\hline N/A & 0 & REMOVAL OF SEPARABLE \\
\hline & & ORGANIC FROM TANK \\
\hline & & $241-\mathrm{C}-103$ SCOPING STUDY \\
\hline
\end{tabular}

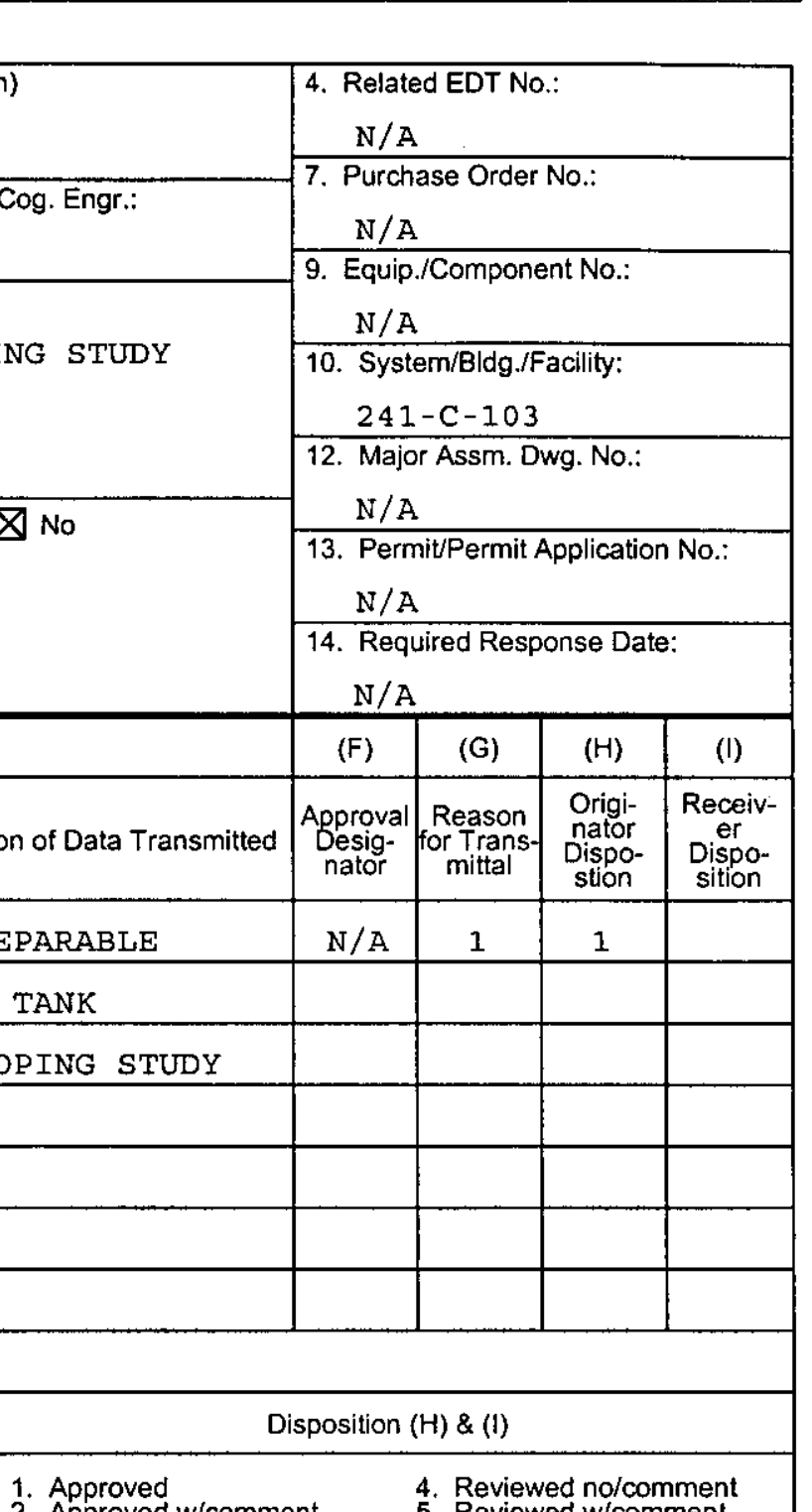

Disposition (H) \& (1)
21. DOE APPROVAL (if required)

Ctrl No. N/A

$\square$ Approved

$\square$ Approved w/comments

$\square$ Disapproved w/comments 


\title{
REMOVAL OF SEPARABLE ORGANIC FROM TANK 241-C-103 SCOPING STUDY
}

\author{
M.R. KOCH \\ CH2M HILL HANFORD GROUP, INC. \\ Richland, WA 99352 \\ U.S. Department of Energy Contract DE-AC06-96RL13200

$\begin{array}{ll}\text { EDT/ECN: } & 624920 \\ \text { Org Code: } & 74 \mathrm{D} 00 \\ \text { B\&R Code: } & \text { N/A }\end{array}$ \\ UC: 2000 \\ Charge Code: 112519 \\ Total Pages: 105
}

Key Words: RPP; Single-Shell Tank; C-103; Organic; Waste

\begin{abstract}
This study is based on previous evaluations / proposals for removing the floating organic layer in $\mathrm{C}-103$. A practical method is described with assumptions, cost and schedule estimates, and risks. Proposed operational steps include bulk organic removal, phase separation, organic washing and offsite disposal, followed by an in-situ polishing process.
\end{abstract}

TRADEMARK DISCLAIMER. Reference herein to any specific commercial product, process, or service by trade name, trademark, manufacturer, or otherwise, does not necessarily constitute or imply its endorsement, recommendation, or favoring by the United States Government or any agency thereof or its contractors or subcontractors.

Printed in the United States of America. To obtain copies of this document, contact: Document Control Services, P.O. Box 950, Mailstop H6-08, Richland WA 99352, Phone (509) 372-2420; Fax (509) 376-4989.

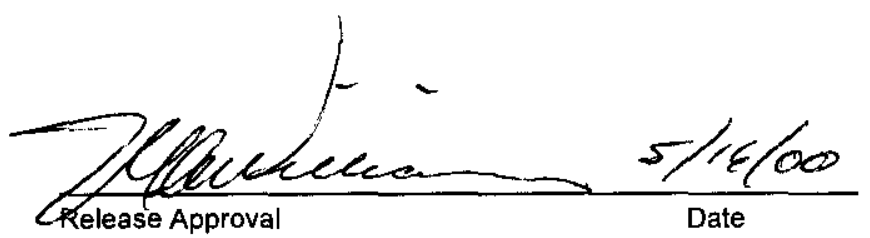

Approved For Public Release 
RPP-6310

Revision 0

\section{Removal of Separable Organic from Tank 241-C-103 Scoping Study}

Date Published

March 2000

Prepared for the U.S. Department of Energy Assistant Secretary for Environmental Management

\section{CH2MHILL \\ Hanford Group, Inc.}

P. O. Box 1500

Richland, Washington

Contractor for the U.S. Department of Energy
Office of River Protection under Contract DE-AC06-99RL14047 
LEGAL DISCLAIMER

This report was prepared as an account of work sponsored by an agency of the United States Government. Neither the United States Government nor any agency thereof, nor any of their employees, nor any of their contractors,

subcontractors or their employees, makes any warranty, express or implied, or assumes any legal liability or responsibility for the accuracy, completeness, or any third party's use or the results of such use of any information, apparatus, product, or process disclosed, or represents that its use would not infringe privately owned rights. Reference herein to any specific commercial product, process, or service by trade name, trademark, manufacturer, or otherwise, does not necessarily constitute or imply its endorsement, recommendation, or favoring by the United States Government or any agency thereof or its contractors or subcontractors. The views and opinions of authors expressed herein do not necessarily state or reflect those of the United States Government or any agency thereof.

This report has been reproduced from the best available copy.

Available in paper copy and microfiche.

Available electronically at

http://www.doe.gov/bridge. Available for a

processing fee to the U.S. Department of Energy and its contractors, in paper, from:

U.S. Department of Energy

Office of Scientific and Technical Information

P.O. Box 62

Oak Ridge, TN 37831-0062

phone: 865-576-8401

fax: 865-576-5728

email: reports@adonis.osti.gov(423)576-8401

Available for sale to the public, in paper, from:

U.S. Department of Commerce

National Technical Information Service

5285 Port Royal Road

Springfield, VA 22161

Phone: 800-553-6847

fax: 703-605-6900

email: orders@ ntis.fedworld.gov

online ordering:

http://www.ntis.gov/ordering.htm

Printed in the United States of America 


\section{EXECUTIVE SUMMARY}

The purpose of this study was to prepare a scoping study and cost estimate on the removal of the separable organic phase from Tank 241-C-103 (C-103). C-103 is a single-shell underground storage tank known to contain about 17,300 liters $(4,570$ gallons) of floating separable phase organic liquid comprised of tributyl phosphate (TBP) and normal paraffin hydrocarbon (NPH).

The current interim stabilization plan assumes the organic layer in the tank will not be removed separately and stored for future disposition. The Department of Energy (DOE), Office of River Protection (ORP) has directed the River Protection Project (RPP) to plan for the removal of the $C-103$ organic layer before interim stabilization.

This study is based on previous $C-103$ evaluations of bulk organic removal technology and partial designs performed in the 1994 to 1996 time frame. It also includes a polishing concept and cost estimate to remove the residue separable organic in $C-103$.

The main unit operations are briefly described in the following bullets:

- The organic removal equipment consists of a skimmer and pump assembly that skims the organic from the surface of the tank liquid and pumps it to the phase separation system. The equipment also includes a closed circuit television (CCTV) system to provide observation of the in-tank operation.

- $\quad$ The phase separation equipment consists of a coalescer assembly that separates the organic from any aqueous carryover and routes the organic phase to the organic treatment system and the aqueous carryover back to the C-103 tank.

- The organic treatment equipment consists of a batch wash tank and connections for wash solution addition from a tanker system. The organic is washed to remove contaminants prior to shipment to the disposal vendor. Once 
decontaminated, the organic phase is routed to the interim storage system. The aqueous is routed to the aqueous return system.

- $\quad$ The treatment system aqueous return equipment consists of the LR56 cask. The aqueous phase is received in the cask and transported and transferred to a double-shell tank via 204-AR.

- Interim storage consists of an International Standard Organization (ISO) tank.

- $\quad$ The transport/disposal equipment consists of a vender-supplied tanker and a loadout station with sampling capability.

While no new separation technology appears applicable since the original 1994-96 work was completed, one disposal site's Waste Acceptance Criteria have significantly changed and will allow the receipt and disposal of the $C-103$ organic.

The overall cost of the bulk removal of organic from $C-103$ is estimated $\$ 8.8$ million. This includes; $\$ 0.4$ million for Engineering, \$1.0 million for Procurement, \$2.2 million for Construction, $\$ 3.5$ million for Operating Contractor Expenses, and $\$ 1.7$ million for Disposal and Transportation. Section 14, Cost Reduction Initiatives, lists several opportunities that could reduce the overall cost, but increase project risk.

The residual organic polishing strategy developed in this report uses the Light Duty Utility Arm (LDUA) and in-tank absorbents. This polishing step is estimated to cost $\$ 1.0$ million.

The main programmatic risk associated this study is the actual concentration of radionuclides in the organic layer and whether the processing and aqueous carryover will increase the projected contamination level above waste acceptance and shipping criteria.

Based on this work and the previous studies, separation and disposal of the bulk C-103 organic layer is a viable alternative and sufficient information is available to prepare a requirement matrix and complete the detail design. 


\section{TABLE OF CONTENTS}

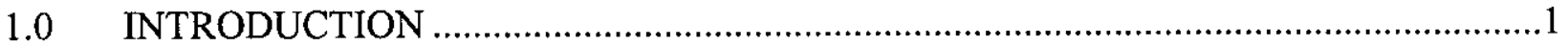

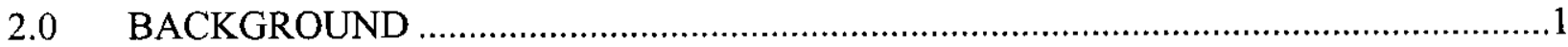

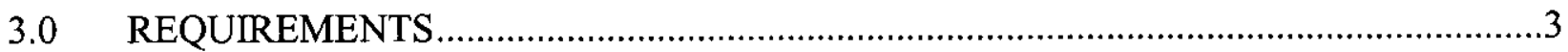

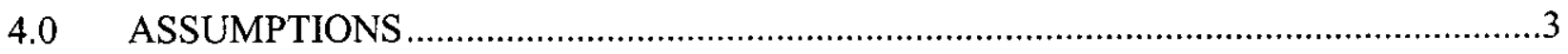

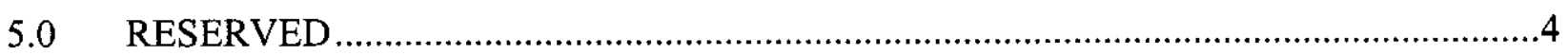

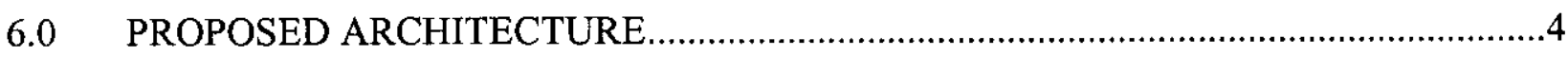

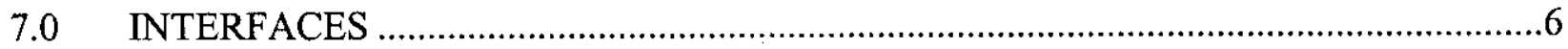

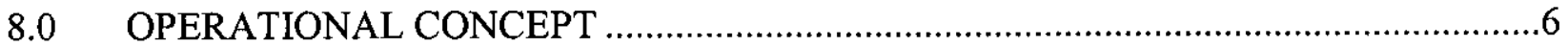

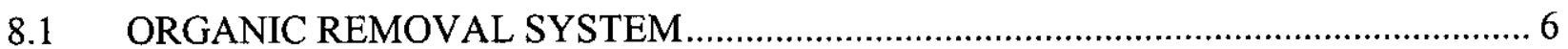

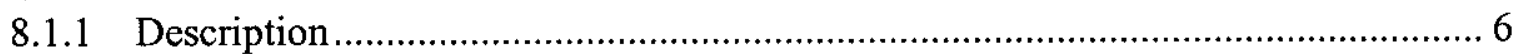

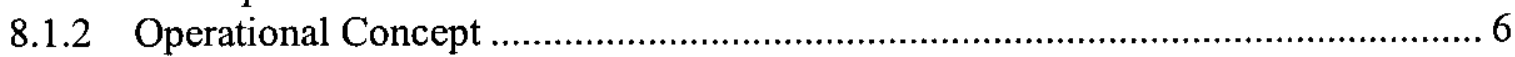

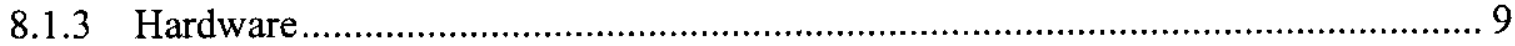

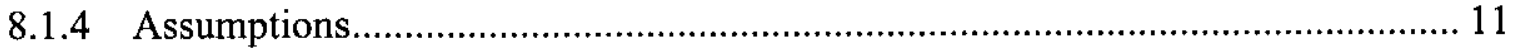

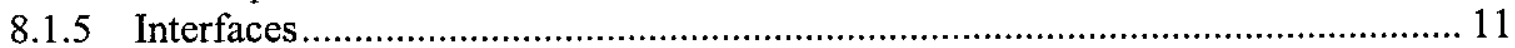

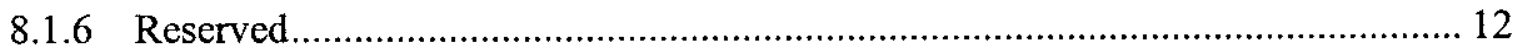

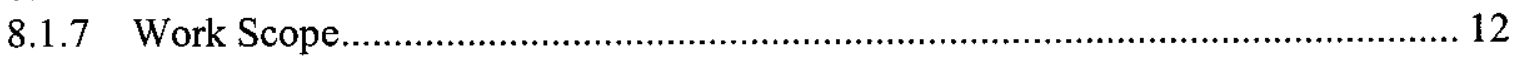

8.2 PHASE SEPARATOR

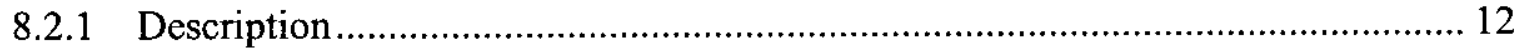

8.2.2 Operational Concept .................................................................................. 13

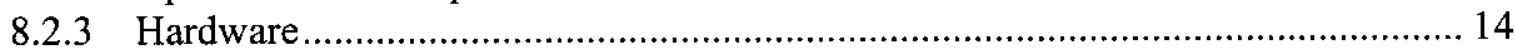

8.2.4 Assumptions.......................................................................................... 18

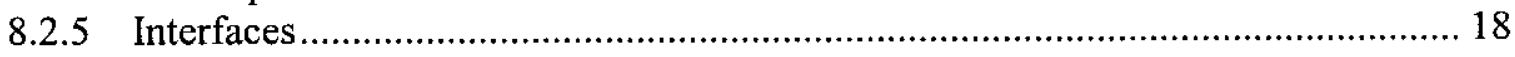

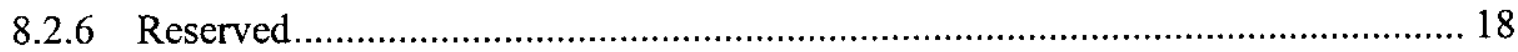

8.2.7 Work Scope............................................................................................ 18

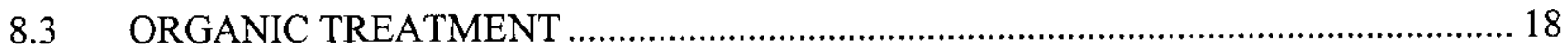

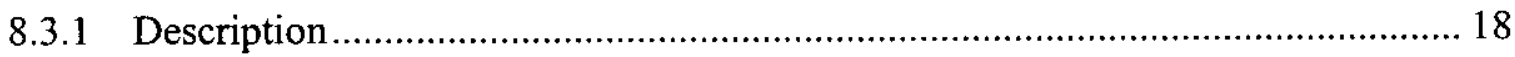

8.3.2 Operational Concept ……………............................................................ 19

8.3.3 Hardware

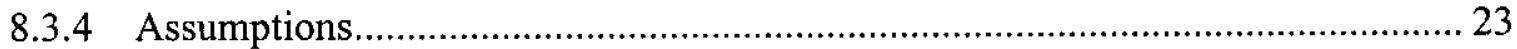

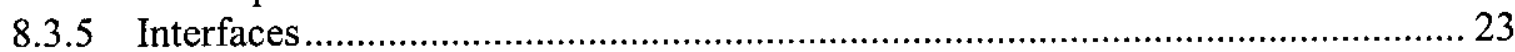

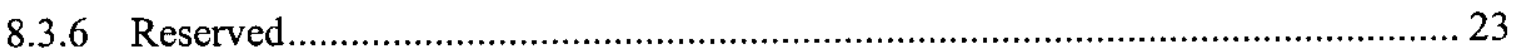

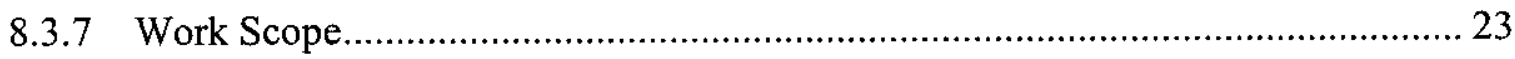

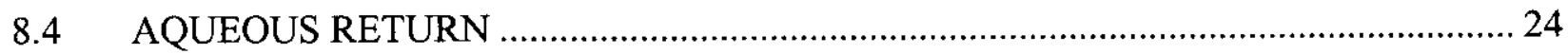

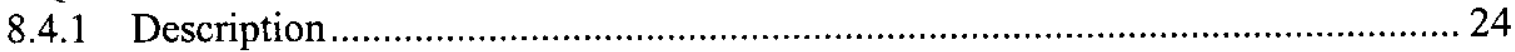

8.4.2 Operational Concept ................................................................................. 24

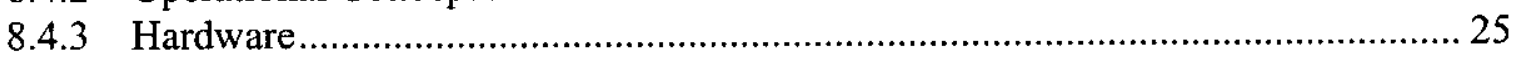

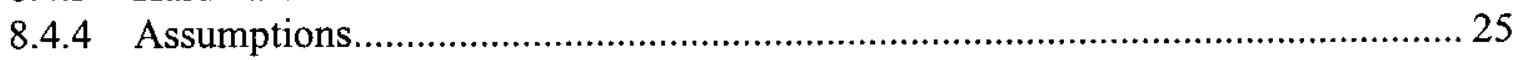

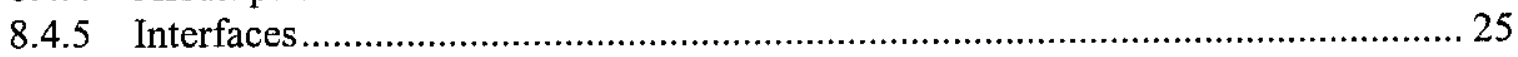

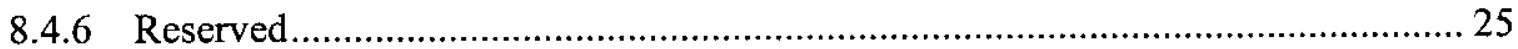

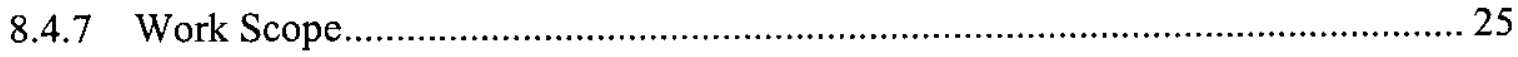




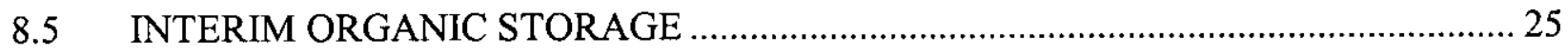

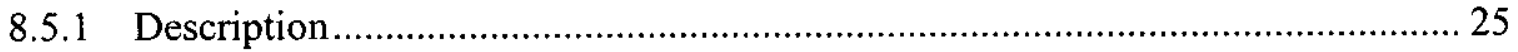

8.5.2 Operational Concept ................................................................................ 25

8.5.3 Hardware

8.5.4 Assumptions............................................................................................. 26

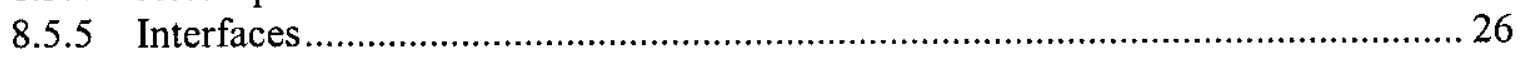

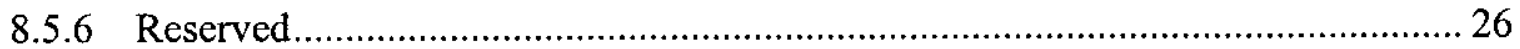

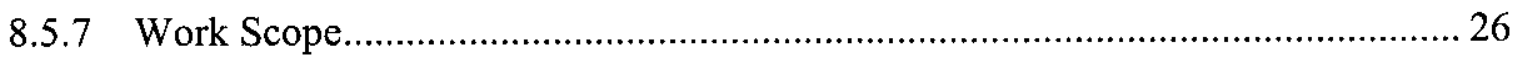

8.6 DISPOSAL /DESTRUCTION SITE (includes transport capability) ……………............. 26

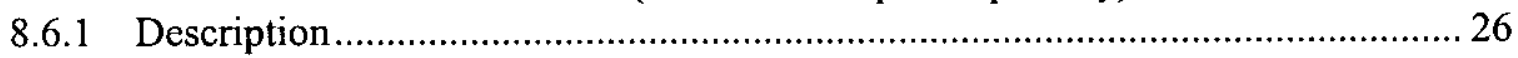

8.6.2 Operational Concept ……………….......................................................... 27

8.6.3 Hardware

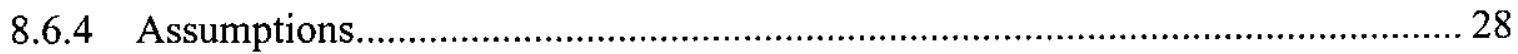

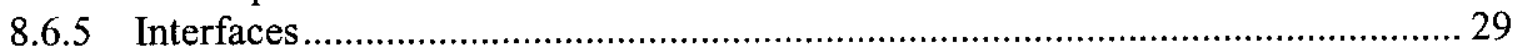

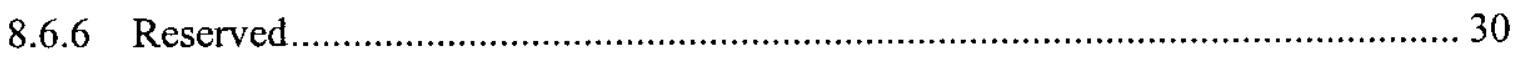

8.6.7 Work Scope

9.0 REGULATORY, PERMIT AND AUTHORIZATION BASIS CHANGES .....................30

$9.1 \quad$ Introduction .............................................................................................. 30

9.2 Assessment Methodology …………………………...................................... 30

9.3 Authorization Basis Modifications .................................................................... 31

9.4 Permits, NOCs, and NEPA Impacts …………….......................................... 32

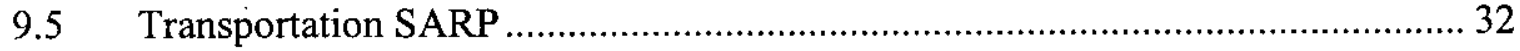

10.0 STARTUP, TESTING AND READINESS STRATEGY .................................................3

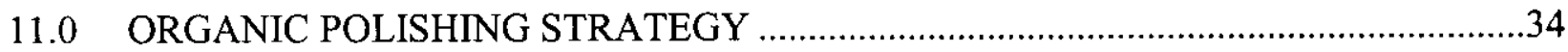

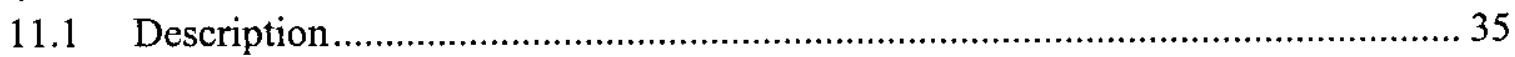

11.2 Operational Concept ……………………........................................................ 36

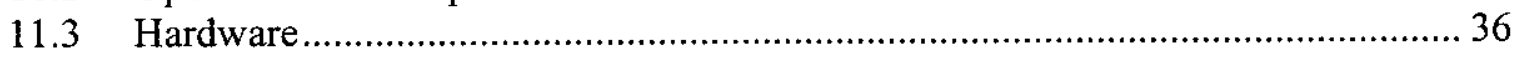

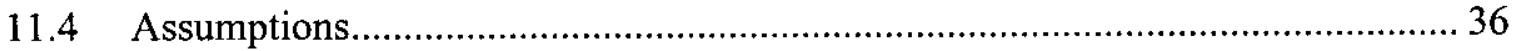

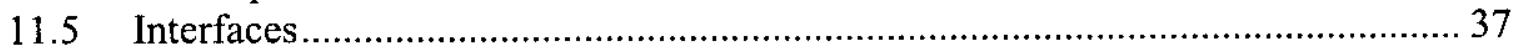

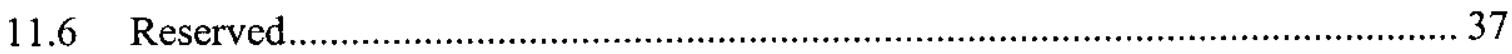

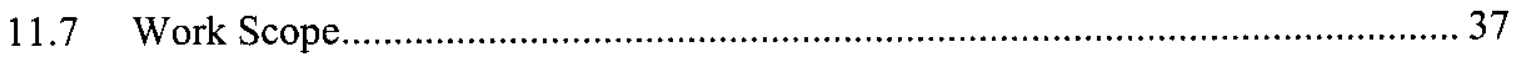

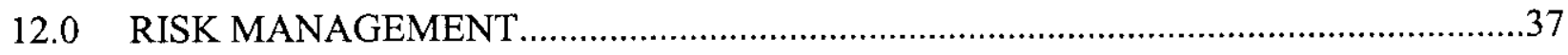

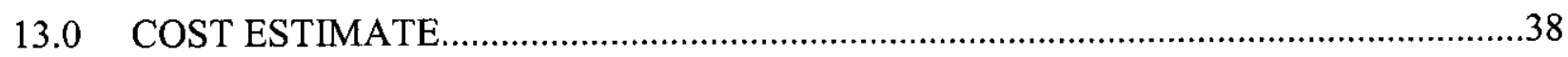

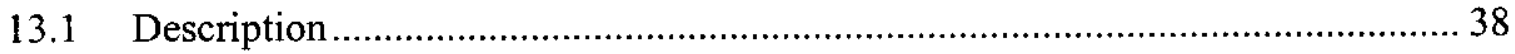

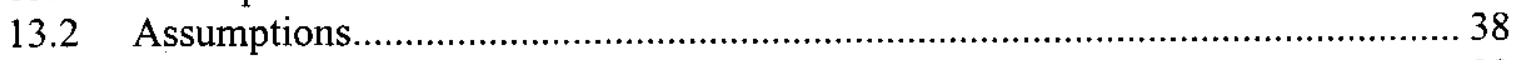

13.3 Cost Basis................................................................................................. 39

13.4 Project Cost .................................................................................................... 39

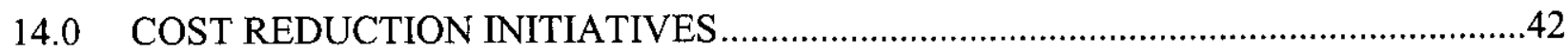

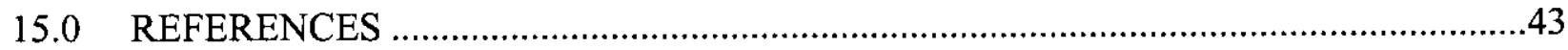




\section{APPENDICES}

Appendix A. Waste Acceptance Criteria ..................................................................... A

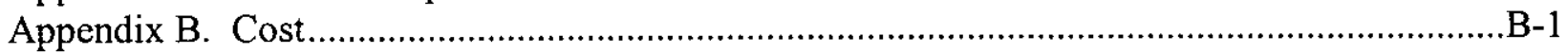

Appendix C. Environmental Permitting Checklist .......................................................

\section{LIST OF FIGURES}

Figure 6-1. Tank C-103 Organic Removal, Treatment and Storage System

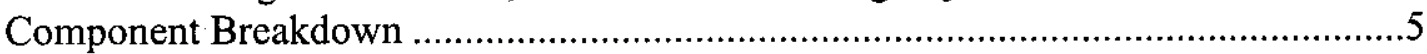

Figure 8-1. Organic Removal System Schematic ............................................................

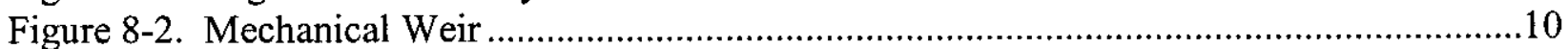

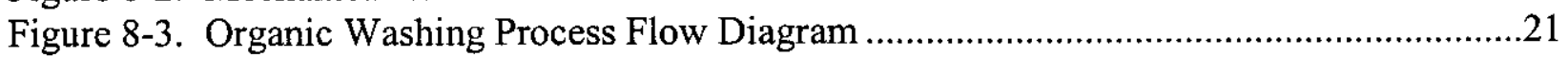

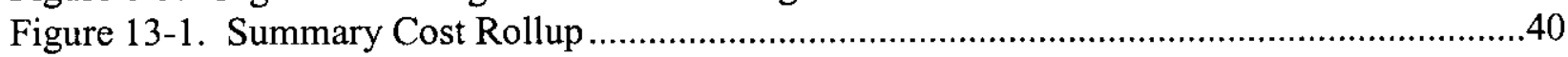

\section{ACRONYMS AND ABBREVIATIONS}

\begin{tabular}{ll}
${ }^{\circ} \mathrm{C}$ & degrees Celsius \\
$\mu \mathrm{m}$ & micron \\
$\mathrm{AB}$ & authorization basis \\
ABU & Acceptance for Beneficial Use \\
ATG & Allied Technical Group of Richland \\
BNFL & British Nuclear Fuel Limited, Incorporated \\
CCTV & closed circuit television \\
cm & centimeters \\
cp & centipoises \\
CRA & Criteria Review Approaches \\
CRS TAP & Chemical Reactions Sub Tank Advisory Panel \\
DCRT & double-contained receiver tank \\
DOE & U.S. Department of Energy \\
DOT & U.S. Department of Transportation \\
DSSI & Diversified Scientific Services Incorporated \\
DST & double-shell tank \\
Ecology & Washington State Department of Ecology \\
EDTA & ethylenediaminetetraacetic acid \\
EPA & U.S. Environmental Protection Agency \\
EReqs & Environmental Permits, Approvals, and Requirements \\
FSAR & final safety analysis report \\
ft & feet \\
g/ml & gram/milliliter \\
gal/min & gallon per minute \\
HEPA & high-efficiency particulate air filter \\
hp & horsepower \\
in & inch \\
\hline
\end{tabular}




$\begin{array}{ll}\text { ISO } & \text { International Standards Organization } \\ \text { JCO } & \text { Justification for Continued Operation } \\ 1 & \text { liters } \\ \text { lb/in } & \text { pounds per square-inch } \\ \text { LDUA } & \text { Light Duty Utility Arm } \\ \text { LSA } & \text { low specific activity } \\ \text { ml } & \text { milliliters } \\ \text { mm } & \text { millimeters } \\ \text { mR/hr } & \text { milliREMS per hour } \\ \text { NEPA } & \text { National Environmental Policy Act } \\ \text { NOC } & \text { Notice of Construction } \\ \text { NPH } & \text { normal paraffin hydrocarbon } \\ \text { NTS } & \text { Nevada Test Site } \\ \text { ORP } & \text { U.S. Department of Energy, Office of River Protection } \\ \text { ORR } & \text { Operational Readiness Review } \\ \text { pSi } & \text { pounds per square inch } \\ \text { PUREX } & \text { plutonium uranium extraction } \\ \text { RCRA } & \text { Resource Conservation and Recovery Act } \\ \text { RL } & \text { U.S. Department of Energy, Richland Operations } \\ \text { ROM } & \text { rough order of magnitude } \\ \text { rpm } & \text { revolutions per minute } \\ \text { RPP } & \text { River Protection Project } \\ \text { RTD } & \text { Resistance Temperature Detector } \\ \text { SAR } & \text { safety analysis report } \\ \text { SARP } & \text { safety analysis report for packaging } \\ \text { SSC } & \text { systems, structures and components } \\ \text { SST } & \text { single-shell tank } \\ \text { TBD } & \text { to be determined } \\ \text { TBP } & \text { tributyl phosphate } \\ \text { TSCA } & \text { Toxic Substance Control Act } \\ \text { TSCAI } & \text { TSCA Incinerator } \\ \text { TSR } & \text { technical safety requirement } \\ \text { USQ } & \text { unreviewed safety question } \\ \text { V } & \text { volt } \\ \text { WFD } & \text { Waste-Feed Delivery } \\ \text { WMH } & \text { Waste Management Federal Services of Hanford, Inc. } \\ \text { wt\% } & \text { weight percent } \\ & \end{array}$




\section{$1.0 \quad$ INTRODUCTION}

The purpose of this study was to prepare a scoping study and cost estimate on the removal of organic from Tank 241-C-103 (C-103). C-103 is a single-shell underground storage tank (SST) used to store hazardous and radioactive waste that was generated during defense production operations at the Hanford Site. It is known to contain about 17,300 liters (4,570 gallons) of floating separable phase organic liquid comprised of tributyl phosphate (TBP) and normal paraffin hydrocarbon (NPH). The liquid organic is floating on an aqueous supernatant layer of approximately 503,000 liters (133,000 gallons) and a sludge layer of approximately 230,000 liters $(62,000$ gallons $)$.

The current interim stabilization plan (Lewis, 1999) assumes the organic layer in the tank will not be removed separately and stored for future disposition. The Department of Energy (DOE), Office of River Protection (ORP) has directed the River Protection Project (RPP) to prepare a scoping study to address removal of the $\mathrm{C}-103$ organic layer before interim stabilization.

This study is based on previous C-103 evaluations of bulk organic removal technology and partial designs performed in the 1994 to 1996 time frame. It covers necessary assumptions, a brief requirements section, proposed architecture, operational concepts, future work required, cost estimates, and a qualitative risk discussion, and cost reduction initiatives. Also included is a polishing concept and cost estimate to remove the residual separable organic in C-103.

\subsection{BACKGROUND}

Tank C-103 was constructed in 1943-1944 and placed into service in August 1946 to receive B Plant metal waste. It was later used to receive Plutonium-Uranium Extraction (PUREX) plant coating waste and other PUREX plant waste. In addition, other various waste solutions from numerous sources were transferred into/through the tank (Carothers, 1988).

The organic liquid in C-103 is believed to have resulted from the transfer of solvent-rich organic wash waste from Tank 241-C-102 in November 1975 (Dukelow, 1996, Volume 2, section 3.3). The organic liquid currently is a mixture of approximately 67 weight percent (wt\%) tributyl phosphate (TBP) and $33 \mathrm{wt} \%$ normal paraffin hydrocarbon (NPH), the primary organic compounds that make up the PUREX Plant solvent. Partial evaporation of the organic liquid during periods of forced ventilation between 1975 and 1992 has reduced the volume of the liquid and depleted the more volatile hydrocarbons that were initially present in the NPH. The organic liquid has a density of $0.876 \mathrm{gram} / \mathrm{milliliter}(\mathrm{g} / \mathrm{ml})$ and a viscosity of $4 \mathrm{cp}$ (centipoises) at 5 degrees Celcius $\left({ }^{\circ} \mathrm{C}\right)$ (Pool and Bean, 1994).

As a result of previous studies by Dukelow $(1995,1996)$, recommendations were made to the DOE that $\mathrm{C}-103$ be interim stabilized by transferring the organic and aqueous liquids to a double-shell tank (DST) for interim storage. Concerns on interim stabilization without removing the organic have been raised by the Chemical Reactions Sub Tank Advisory Panel (CRS TAP) and the Defense Nuclear Facility Safety Board. 
In 1998, the State of Washington Department of Ecology (Ecology) did not approve proposed changes to the Hanford Federal Facility Agreement and Consent Order milestone M-41-22 for completing interim stabilization of the remaining SSTs. Subsequently, the DOE, U.S. Department of Justice, and State of Washington developed a new plan for accelerating the program under a consent decree. One consent decree commitment specifically addresses C-103. This commits DOE to complete the following activities no later than December 20, 2000:

- Determine whether the separable organic layer and pumpable liquids will be pumped from C-103 together or separately, and

- $\quad$ Establish a deadline for initiating pumping of C-103.

The historical work has shown that saltwell pumping the tank does not create a new safety issue. The current baseline is interim stabilizing STET the tank using a saltwell pump.

The DOE letter 99-PD-041 directed the contractor to plan for the removal of the C-103 organic layer before interim stabilization. The DOE letter requested a path forward for removing the bulk separable organic layer and for a polishing step path forward to handle the residue organic in $\mathrm{C}-103$.

The contract between DOE and the Privatization Contractor for Phase 1 immobilization of tank waste contains a requirement that the Project Hanford Management Contractor will not deliver a feed that contains a "...visible, separate organic layer." The criterion is based on suspected deleterious impacts of the organic on the PC's evaporator and ion exchange (pretreatment) system. Neither the Waste Feed Delivery (WFD) nor the Private Contractor's pretreatment system baseline includes an organic removal/destruction process. Furthermore, no such systems are in design and no contingency has been provided, to date, for removal of separable organic. However, feed material from C-103 is currently not part of the minimum order quantity for Phase 1.

Organic solvents have mainly been studied/evaluated from the context of tank safety (i.e., organic fires, organic-nitrate reactions, and flammable gases). Work competed more recently has addressed retrieval, storage, and destruction options for organic in C-103, which has a known floating organic layer several inches deep. Several options were reviewed for handling the separable phase organic in $\mathrm{C}-103$.

Two process alternatives that received the most attention were:

- Separate the organic in C-103 from the aqueous phase for storage in an aboveground tank for eventual disposal/pretreatment at an incinerator site, and

- $\quad$ Saltwell pump the tank liquid contents to a double-shell tank (DST). At the DST, the organic would be subject to decomposition in the highly alkaline solution and evaporation due to the active ventilation system.

This report focuses on the first alternative, removal of the $\mathrm{C}-103$ separable organic. 


\subsection{REQUIREMENTS}

The creation of detailed performance requirements was not within the scope of this study. The requirements below were developed only in sufficient detail to prepare cost estimates of the removal, treatment, interim storage and disposal of the C-103 organic phase. Lower tier assumptions for individual unit operations are listed in Section 8.

- Remove the bulk of organic phase from C-103. The end point for the bulk removal is anticipated to be within 2 millimeters $(\mathrm{mm})$ of the aqueous interface.

- Remove particles $\geq 5$ micron $(\mu \mathrm{m})$ from the feed stream to reduce downstream radiation exposure.

- $\quad$ Reduce aqueous carryover to reduce radiation exposure such that the downstream equipment can be contact maintained.

- Provide an organic treatment process to allow the organic stream to meet shipping and disposal requirements.

- Provide capabilities to return aqueous waste to a DST/double-contained receiver tank (DCRT).

- $\quad$ Provide necessary sampling, interim storage, and load out capabilities.

- Comply with regulations governing environmental interface of radioactive and toxic materials.

- Facilitate decontamination for decommissioning and disposal through system design and construction.

\subsection{ASSUMPTIONS}

The following assumptions relate to the removal, treatment, interim storage and disposal of the C-103 organic phase:

- Technologies employed in the systems are commercially and industrially proven and adaptable directly for field use.

- Existing facilities and plant structure will be used to the extent possible.

- $\quad$ Previous testing performed primarily to select and validate concepts and verify performance for application in these systems is valid.

- No new safety or environmental requirements are imposed that will affect the scope definition.

- $\quad$ Site support infrastructures are available as required. 
- Current sample analysis/organic contamination level does not change during processing.

- Recovered organic material may require additional treatment to meet shipping and/or disposal site requirements.

- A licensed commercial operator will perform final disposal of the separated organic.

- $\quad$ Passive ventilation mode for the tank and new installations will be acceptable.

- Separated aqueous phase will be returned to existing tank farm systems without treatment or sampling.

- There is no numerical end point criteria for the C-103 polishing step.

- The equipment used for this activity will be flushed and disposed of onsite.

\subsection{RESERVED}

\subsection{PROPOSED ARCHITECTURE}

For the purposes of this scoping study, organic removal consists of the following major process functions summarized in Figure 6.1:

- Organic removal

- $\quad$ Phase separation

- Organic treatment

- Aqueous return

- Interim storage

- Transport/disposal.

The organic removal equipment consists of a skimmer and pump assembly which skims the organic from the surface of the tank liquid and pumps it to a surge tank in the phase separation system. The equipment also includes a closed circuit television (CCTV) system to provide observation of the in-tank operation.

The phase separation equipment consists of a coalescer assembly that separates the organic from any aqueous carryover and routes the organic phase to the organic treatment system and the aqueous carryover back to the $\mathrm{C}-103$ tank.

The organic treatment equipment consists of a batch wash tank and connections for wash solution addition from a tanker system. The organic is washed to remove contaminants prior to shipment to the disposal vendor. Once decontaminated, the organic phase is routed to the interim storage system. The aqueous is routed to the aqueous return system. 
The aqueous return treatment process consists of the LR56 cask. The aqueous phase is received in the cask and transported and transferred to a DST via 204-AR.

The interim storage equipment consists of an International Standards Organization (ISO) tank or potentially the final treatment tank/decanter can be used to store clean organic prior to loading into the transport vessel.

The transport/disposal equipment consists of a vender-supplied tanker and a loadout station with tank sampling capability.

The removal of residual organic from C-103 (polishing step) is discussed in Section 11.

\section{Figure 6-1. Tank C-103 Organic Removal, Treatment and Storage System Component} Breakdown.

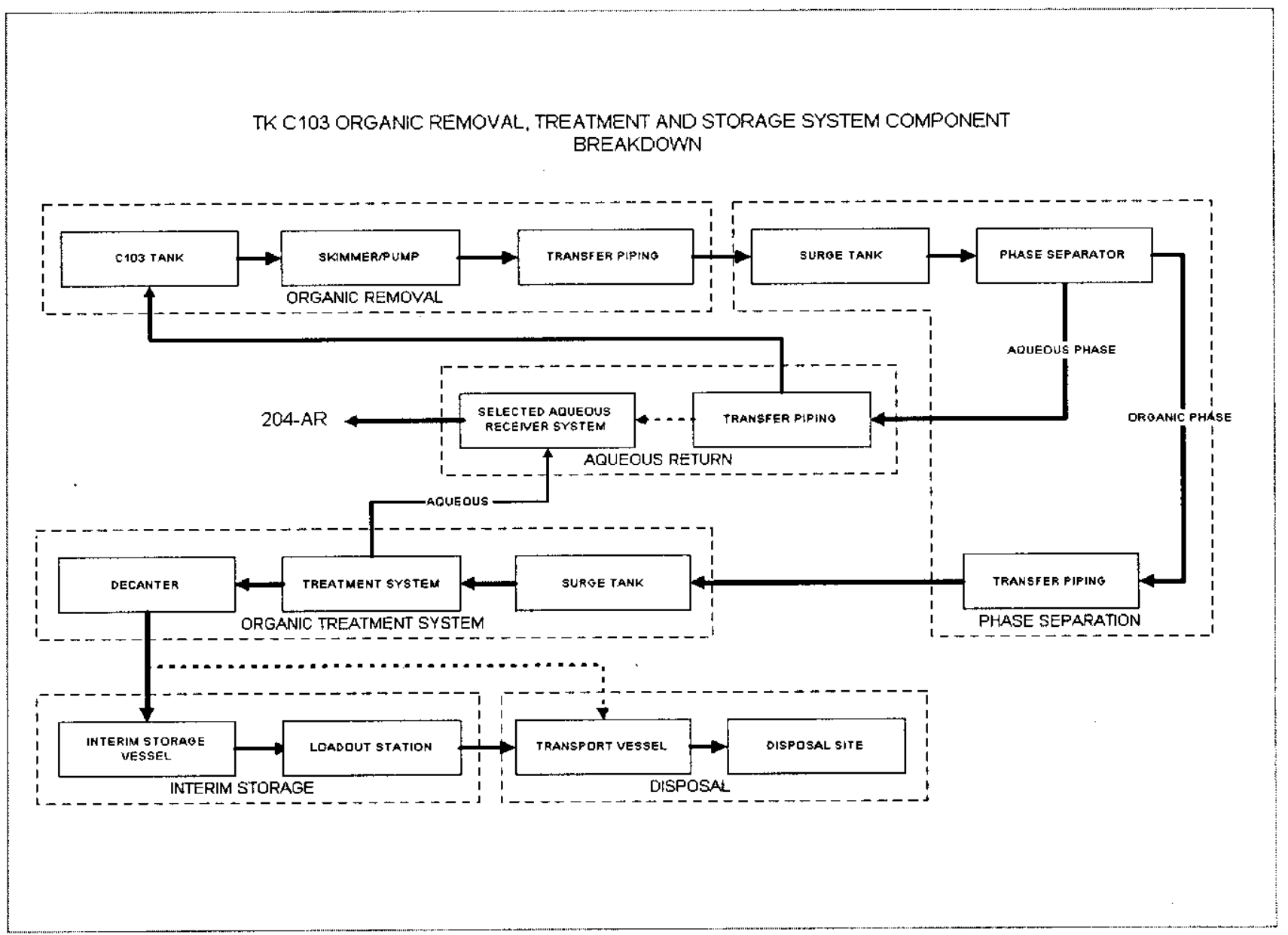




\subsection{INTERFACES}

The organic removal system interfaces with the following facilities and functions:

- $\quad$ Tank C-103.

- $\quad$ Riser 2 for skimmer pump access, and risers yet to be determined for organic level measurement and CCTV access.

- $\quad$ Power from existing $\mathrm{C}$ farm systems.

- $\quad$ Aqueous returns to designated DST via 204-AR.

- $\quad$ Portable decontamination system (chemical tanker).

- $\quad$ Site shipping and transportation personnel and requirements.

- $\quad$ Tank farms chemical make-up and flushing equipment/tanker.

\subsection{OPERATIONAL CONCEPT}

The primary goal of the organic removal system is to reduce the volume of organic material in C-103 and to remove residual radionuclide contamination from the organic so that it can be sent for off-site disposal. The organic is skimmed and pumped from the tank with a low-capacity, positive displacement pump, and routed through a coalescer device in a shielded enclosure. The coalescer separates the entrained aqueous phase from the organic and routes the aqueous back into the tank. The separated organic is routed to the organic treatment system. The organic treatment system uses a batch alkaline wash process to remove radionuclide contamination to a level that allows the organic to be shipped. The organic is then held in an interim storage container and from there, loaded into the transport vessel through a loadout station and shipped offsite for treatment and disposal.

Each of the proposed architecture systems identified in Section 6.0 is described in detail below.

\subsection{ORGANIC REMOVAL SYSTEM}

\subsubsection{Description}

The organic removal system is installed to facilitate removal of a 2-inch (in) separable organic layer from the tank and transfer it to a phase separation system. The organic layer is floating on a layer of aqueous supernate estimated to be 1 to 4 feet (ft) thick. The organic removal system is designed to skim off the organic layer while minimizing mixing within the underlying supernate layer and between the organic and supernate layers.

\subsubsection{Operational Concept}

The skimmer pump assembly is installed in Riser 2, a nominal 12-in diameter interface. The skimmer preferentially removes the organic layer. The skimmer, by virtue of its buoyancy and 
weir design, initially removes only organic, but as the depth of the organic layer decreases, the skimmer begins removing an increasing quantity of aqueous with the organic. The skimmed material is then pumped from the skimmer to a phase separation system external to the tank, where any aqueous carryover is separated from the mixture and returned to the tank (Figure 8.1).

The pump-processing rate is variable with a nominal capacity of 2 to 3 gallons per minute ( $\mathrm{gal} / \mathrm{min}$ ) and a maximum design rate of $5 \mathrm{gal} / \mathrm{min}$. Initial pumping rates are the highest and decrease to a fraction of a gallon per minute as the depth of the organic layer decreases to the required residual level of $2 \mathrm{~mm}$. This residual level is based on studies performed by Bruelbach (Bruelbach 1994), Fauske and Associates, Incorporated (FAI 1994), and onsite testing of equipment and simulants. The total operating time for actual, on-line organic removal is expected to be in the range of 5 to 30 days based on continuous 24 hour-per-day operation. The hardware and arrangement are described in Section 8.1.3.

The system is operated by means of a microprocessor control system located at a central control station. Liquid flowrate from the skimmer is controlled manually from the control station. Variable speed pumping capability minimizes the aqueous carryover toward the end of the pumping cycle.

A decontamination collar installed above the riser provides the means to decontaminate the skimmer pump assembly as it is being removed from the tank. The skimmer pump assembly is attached to a shielding enclosure. This provides riser closure, a means to support the skimmer pump assembly in the tank, and an exit interface route for the piping to a phase separation system.

A CCTV system provides the means to monitor in-tank operation at a central control station.

The planned process is to lower the skimmer pump assembly by crane into the riser. Critical lift procedures will be used if necessary. The floating organic will be removed to within $2 \mathrm{~mm}$ of the aqueous interface with a minimum intake of aqueous. A probe lowered into the tank through a different riser will determine the aqueous interface. Following removal and decontamination, the nominal 35-ft-long skimmer pump assembly support will be cut into appropriate lengths for disposal.

Organic removal tests indicate that efficient removal of the organic can continue until the organic layer reaches a minimum height of less than $1 \mathrm{~mm}$. When the organic layer height reaches its minimum limit, the organic layer breaks apart, forming pools separated by uncovered aqueous. At this point, the flow of organic towards the skimmer becomes very inefficient.

In-line radiation monitoring will be used to detect an increase in aqueous phase carryover. This allows better control of operations and lower system radiation levels. The system will be designed for both daily and extended ( $>2$ day) shutdowns and for continuous operation.

Startup of the organic removal system will follow a standard procedure. Appropriate valves at the shielding enclosure and at the phase separation system will first be positioned and confirmed. The desired pump flowrate will be set and instrumentation operability will be verified. During normal pumping operation the organic layer and some supernate will be skimmed from the tank and pumped to the phase separation system. 
Figure 8-1. Organic Removal System Schematic

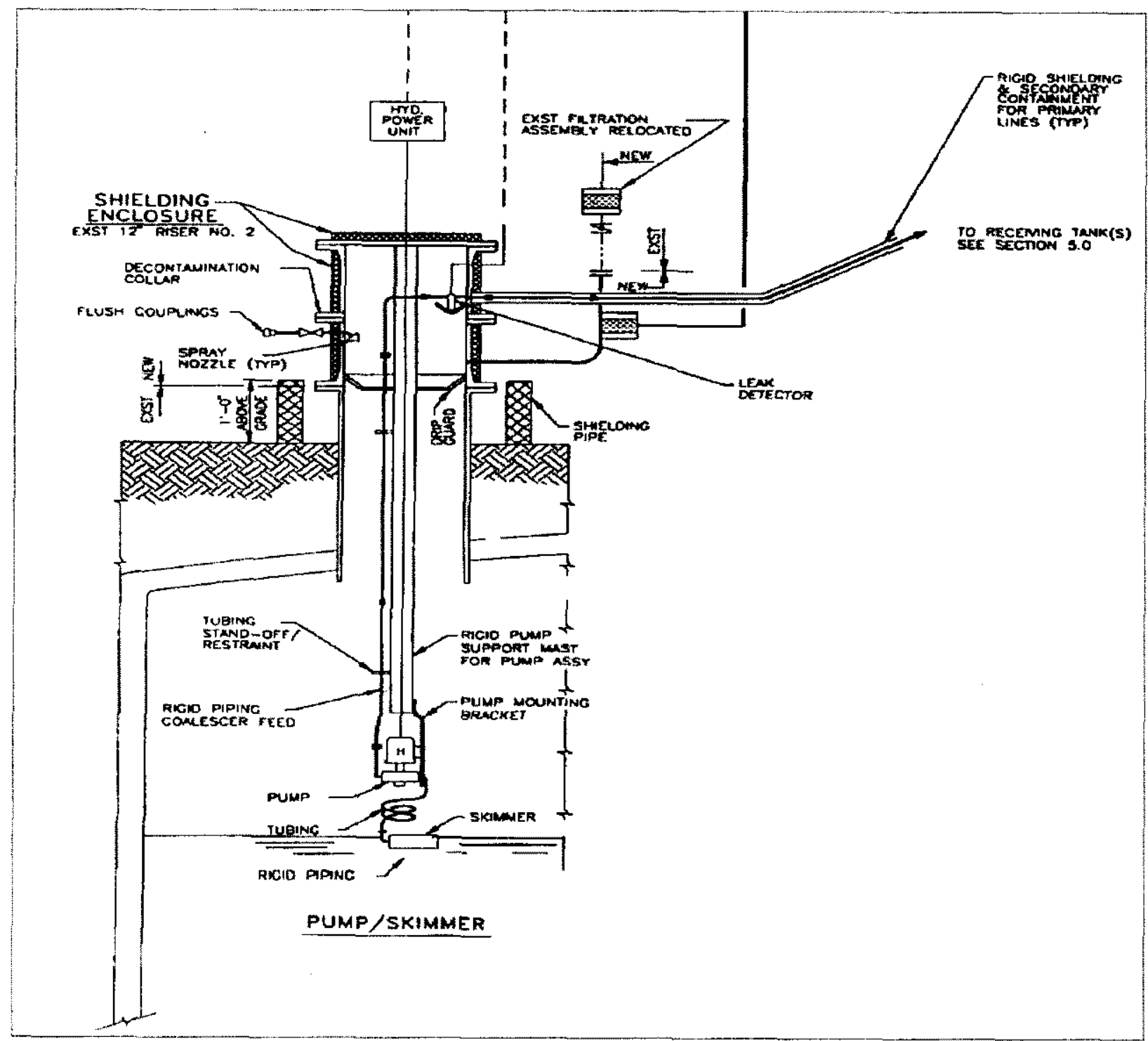

Shutdown of the system follows a standardized procedure. For short (overnight) shutdowns, the piping will be drained to prevent freezing during cold weather. For longer-term (weekend or longer) shutdowns and shutdowns for equipment maintenance, the piping may be drained and flushed with small volumes of water. The resulting flush water will be discharged to the tank. Appropriate valves in the phase separation system are positioned to prevent backflow to the skimmer pump. Backflushing of the skimmer pump discharge is routed back through the pump with the pump operating in reverse.

During final shutdown and removal, flushing is repeated, piping, hydraulics, and auxiliary systems connected to the system are disconnected and the enclosure and pump support are lifted from the tank while the decontamination collar is used to spray the equipment with 
decontamination water. Following successful removal of the skimmer pump assembly, the decontamination collar is removed, and a blind flange placed on the tank riser.

The system is designed to minimize pump cavitation or suction starvation by correct placement of the pump assembly and by flow control. Pump over-pressurization is limited by design and by use of hydraulic controls. The system includes automatic shutdown of the pump on high pressure.

\subsubsection{Hardware}

The organic removal system consists of three main components: (1) a skimmer pump assembly, (2) a decontamination collar, and (3) a shielding enclosure. The skimmer pump assembly is composed of a skimmer, pump, and hydraulic motor. The skimmer pump assembly is suspended in the riser on a solid support mast. A hydraulic drive unit and associated electric motor are located external to the tank and are hydraulically connected to the skimmer pump assembly. The decontamination collar contains spray nozzles for decontamination. The shielding enclosure shields the top of the riser and provides a solid base to mount the support mast for the pump assembly. A CCTV system provides in-tank observation of the pumping operation.

The skimmer is a modified Douglas Engineering weir skimmer, model 650-SHX Skim-Pak ${ }^{\mathrm{TM}}$. It is a stainless steel rectangular float with a central sump. Entry to the sump is from a floating weir hinged to the body of the skimmer. In front of the weir is an elastomer flap. This flap provides the liquid-tight seal to the aqueous solution below the organic. The skimmer requires modification to replace the weir flap with one that is morc chemically resistant (Figure 8.2). Additional development is required to select an appropriate material for the weir flap.

The pump is a modified Waukesha ${ }^{\mathrm{TM}}$ universal positive displacement pump Model 18. It is a dual-lobe, positive displacement type that minimizes mixing/agitation of fluids with discrete particles. The pump is positioned on a foot bracket base approximately $3 \mathrm{ft}$ above the liquid surface. A flexible connection (Kynarß coil tubing) connects the pump inlet to the skimmer float outlet. The connection between the float and the pump allows a minimum of $1 \mathrm{ft}$ elevation difference in the tank to prevent interference with the float operation. A safety bridle is attached between the pump and float to allow recovery should the flexible connection break. The pump self-primes to $3 \mathrm{ft}$, uses mechanical seals and has self-drainage capability.

The hydraulic motor is a Ross Operation Torqmotor ${ }^{\circledR}$ MG Series Roller Vane motor. The hydraulic motor is directly coupled to the pump shaft and mounted to the same foot bracket base as the pump. The inlet and outlet to the motor are ported at the rear. The motor is attached to the hydraulic drive unit through connectors external to the shielding enclosure. The hydraulic system was selected to eliminate an in-tank spark source. Authorization basis changes since 1994 may allow an in-tank motor, reducing system costs and complexities.

The hydraulic drive unit is a Paul-Munroe Rucker ${ }^{\mathrm{TM}}$ hydraulic drive unit, driven by a 3 horsepower (hp), 230 volt (V), 3-phase electric motor. The drive unit has the capability to reverse the flow with a directional flow control switch and operate at variable speeds through a 
Figure 8-2. Mechanical Weir

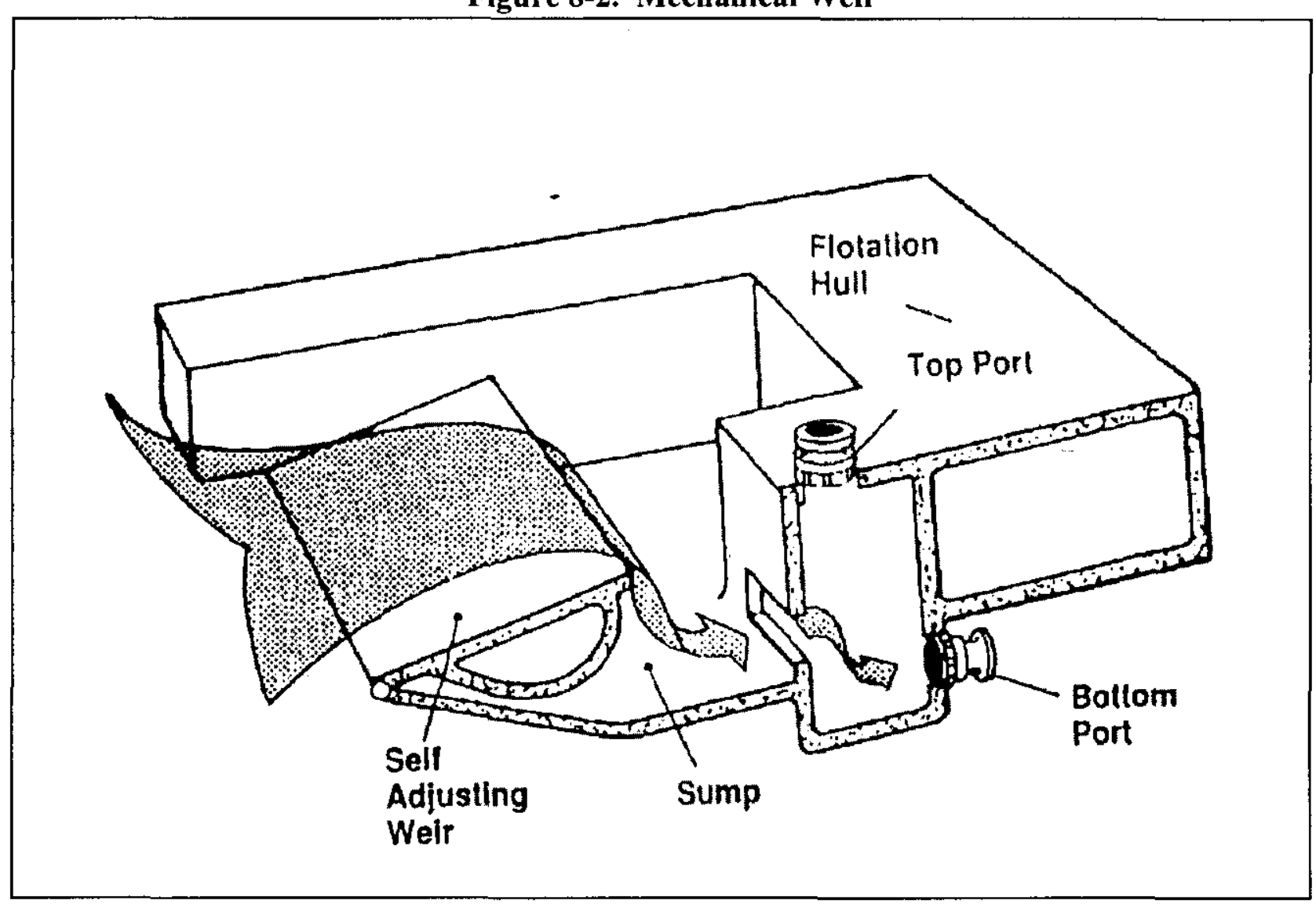

flow controller. The drive unit and motor are located on a concrete pad external to the shielding enclosure. The hydraulic system is reversible via a directional flow control switch and can operate at variable speeds via a flow controller.

The decontamination collar consists of a 12-in diameter stainless steel pipe section with mounting flanges on both ends. The collar contains three high-pressure decontamination nozzles located equidistant around the collar. The nozzles are connected to a pipe ring located on the exterior of the collar. A self-sealing, no drip, quick disconnect flush connection is installed on the pipe ring to supply inhibited water from a portable decontamination system. A drip guard is installed internally on the lower end of the collar to assist in the decontamination operation. Shielding is installed on the external surface to minimize exposure during organic transfer. The collar assembly is connected to the C-103 High-Efficiency Particulate Air filter (HEPA) to assure passive ventilation of the tank headspace.

The shielding enclosure section consists of a 12-in diameter stainless steel pipe section with a mounting flange on the lower end and a cover plate on the upper end. A four-inch extension is installed on the side of the enclosure to facilitate connection of the pump outlet piping to the phase separator. All penetrations in the enclosure will be air- and liquid-tight to prevent the accidental release of contamination. A 6-in diameter pump support mast will be attached to the underside of the enclosure cover plate and extended into the tank approximately $30 \mathrm{ft}$. The 
bracket on the lower end of the mast will rigidly support the pump and motor in a vertical shaft orientation without rotation. A leak detection system is installed in the 4-in extension to detect leakage from the pipe connection. Shielding is installed on the external surface to minimize exposure during organic transfer.

External piping connected from the shielding enclosure extension to the phase separator surge tank is of the same design as the SY-101 piping.

Instrumentation to monitor the organic removal system operation consists of a microprocessor control system. Process control parameters include hydraulic drive speed, motor controls and status information (motor running amps, motor temperature, motor running status), organic flow rate, feed tank liquid level, phase separator and treatment surge tank liquid levels, and interim storage tank liquid level.

Parameters also include leak detection and radiation monitoring information.

The CCTV system consists of a camera and lights installed in riser TBD and a monitoring/recording station located at the system control center. The system has normal pan, tilt and zoom controls typical to these types of systems.

\subsubsection{Assumptions}

The following assumptions relate to the removal of the $\mathrm{C}-103$ organic phase:

- Technologies employed in the systems are commercially and industrially proven and directly adaptable for field use.

- $\quad$ Previous testing performed primarily to select and validate concepts and verify performance for application in these systems is valid.

- The previous weir flap material testing indicated a three month design life.

\subsubsection{Interfaces}

The organic removal system interfaces with the phase separator and the decontamination tanker.

Process control interface via microprocessor control system includes variable speed drive control, organic flow rate, feed tank liquid level, phase separator and treatment surge tank liquid levels, and interim storage tank liquid level. System shut-off will occur if a leak is detected or radiation limits are exceeded.

Process piping includes one section of double containment piping that connects the pump discharge line from the shielding enclosure to the phase separator surge tank. The secondary containment drains back through a weep hole into the shielding enclosure.

Electrical interface includes a 3-phase electrical distribution system. 


\subsubsection{Reserved}

\subsubsection{Work Scope}

The following activities are required to assure an effective organic removal system life cycle:

- $\quad$ Completion of studies on the operation of the Douglas Engineering Skim-Pak@ Model 8500-AS skimmer pump and alternate weir flap material.

- Design and construction to include skimmer flap material selection.

- $\quad$ Riser preparation (remove existing equipment, etc).

- $\quad$ Skimmer, level and CCTV subsystem installation.

- $\quad$ Test procedure development.

- $\quad$ Readiness documentation development.

- $\quad$ Operating procedure development.

- $\quad$ Process testing and readiness performance.

- Organic removed to the phase separator surge tank.

- $\quad$ Skimmer, level and CCTV subsystem removal.

- $\quad$ Equipment decontamination and disposal.

\subsection{PHASE SEPARATOR}

\subsubsection{Description}

Separation of the organic aqueous product stream will be performed by the phase separator system, specifically a coalescer installed inside of the separator enclosure. Separation will be performed prior to transfer of the organic to the organic treatment system. Provisions will be made in the design to pump the organic back through the phase separator system if further separation is required before the organic is transferred to the organic treatment system. The separated aqueous stream will be transferred back to C-103.

A coalescer was selected for the aqueous-organic separation because of its demonstrated capability to separate two phases with a small difference in the surface tension into two homogenous streams. A comparable gravity settler decanter was considered unacceptable due to the larger size, which would require a larger enclosure with more shielding. Another device investigated for separation of the organic was the liquid-liquid centrifuge. The main disadvantage of the centrifuge is that it is a complex machine and complex machines typically can have maintenance problems. Any breakdown at tank farms would present obvious 
difficulties. Aqueous removed by the skimmer pump will be separated from the organic to the extent that the entrained aqueous in the organic is reduced to a fraction of $1 \%$ by volume.

\subsubsection{Operational Concept}

The skimmer pump transfers the $\mathrm{C}-103$ organic through the coalescer to the organic treatment system. As the mixture of aqueous to organic increases with the decrease in the organic level in C-103, the interface between the two phases will tend to vary. An interface control valve in the aqueous return maintains the interface at a constant level within the coalescer.

The coalescer is constructed of 6 -in schedule 40 pipe fabricated in the shape of a tee. The coalescer is installed with the long leg in the horizontal position and the two short legs in a vertical orientation. The feed is introduced into the horizontal leg of the coalescer, which contains a hollow, cylindrical spun glass coalescer element. The emulsion of C-103 aqueous and organic waste flows radially from the hollow core of the coalescer element to the exterior. The density of the spun glass in the coalescing element is varied radially from the interior to the exterior of the element. Initially, the fluid passes through a low-density spun glass zone that strips away any colloidal dirt film that surrounds the droplets. The second zone is high-density spun glass where the droplets are brought into close contact and begin to coalesce. A second zone of low-density spun glass increases droplet size and a screen covering the coalescing element is the site for droplet release. The coalescing element is manufactured without adhesives or binders that could be degraded by chemicals or radiation. The spun glass is resistant to both.

The enlarged droplets formed in the coalescing element separate by gravity into two distinct phases. The fluid velocity through the coalescer is sufficiently low to allow fine droplets of aqueous or organic to migrate to the respective phases before exiting the unit. The aqueous accumulates in the down-leg of the "tee" and the organic rises and exits the coalescer through the upper section of the "tee." Performance testing of the coalescer was performed with chemically equivalent simulants, which included additives to further simulate the disengaging times determined by observing actual tank waste organic/aqueous samples. This testing has shown the organic outlet stream will contain no more than $0.2 \%$ aqueous phase.

Temperature affects coalescer performance. The lowest temperature the coalescer has been operated at, using simulants, is $20^{\circ} \mathrm{C}$. Efficient operations have been achieved at temperatures less than $25^{\circ} \mathrm{C}$. Better results have been achieved at slightly elevated temperatures $\left(40^{\circ} \mathrm{C}\right)$. In $\mathrm{C}-103$ the tank temperature is about $46^{\circ} \mathrm{C}$.

The aqueous drains into the drain tank and is pumped by a positive displacement pump to C-103 through a double-encased transfer line. The drain tank is sized to accommodate twice the volumetric capacity of the aboveground system, excluding the organic treatment system

The drain tank also serves as a flush tank. This tank is vented to the separation enclosure. The open vent prevents the tank from becoming pressurized and forcing process solution out of the separation enclosure through the flush connection. Flush solution added to this tank can be circulated through the filters and coalescer and returned to the drain tank. After the operation is complete, all separation enclosure piping can be flushed via the drain tank. 
A sump leg and valve allow the drain tank pump to return any accumulated aqueous or flush liquids in the enclosure back to $\mathrm{C}-103$ via a subsurface addition leg to minimize in-tank mixing.

The phase separator system will be designed so that the line from the separations enclosure to the organic treatment system drains back to the separations enclosure; and the line connecting the separations enclosure to $\mathrm{C}-103$ drains back to $\mathrm{C}-103$. Alternatively, if this is not possible, vacuum breakers shall be installed at the high point in the lines. The vacuum breakers shall be vented back to the enclosure or directly/indirectly to $\mathrm{C}-103$ headspace.

Flowmeters on the coalescer feed and aqueous drain lines are of primary importance to the skimmer operation. The skimmer pump flow rate is reduced as the quantity of organic in C-103 is reduced or the quantity of aqueous is increased. This will be measured using radiation detectors mounted on the transfer line. Reducing the pumping rate reduces the quantity of entrained aqueous removed in the skimming operation. The pumping rate is initially highest when the skimmer is removing pure organic. The coalescer feed flowmeter indicates to the operator that the desired skimmer flow rate is being maintained and the microprocessor controller calculates, totals, and displays the organic processed. The pumping rate is reduced when the skimmer pump begins removing aqueous. The fractional flow of aqueous at the lower pumping rates varies from $10 \%$ to $90 \%$ of the total flow, hence the aqueous flowmeter has a lower flow rate range than the feed flowmeter. Performance testing of the combined system will determine the optimum operating parameters. The flow rate from both flowmeters and the total organic and aqueous recovered is displayed in the control trailer.

Gauges located on the upstream and downstream side of the prefilters and the coalescer read pressures. The pressure gauges are the only locally mounted instruments in the enclosure. A high differential pressure between upstream and downstream gages indicates a plug. The flowmeter on the feed to the coalescer will actuate an interlock on low flow shutting down the skimmer pump.

\subsubsection{Hardware}

\section{Hardware Requirements:}

The phase separator system enclosure shall be vented through a HEPA filter located at the enclosure. The enclosure vent line shall connect to the $\mathrm{C}-103$ vent upstream of the filters.

The phase separator system shall be capable of removing all particles $\geq 5 \mu \mathrm{m}$ from the feed stream to the coalescer.

The phase separator system shall be designed to contain leaks in the piping containment and the separation enclosure.

The coalescer and all related equipment shall be designed for the life of the project. Flushing the coalescer and selected piping to maintain required performance and acceptable exposure levels is included in the system. Flushes will be transferred back to C-103.

All equipment associated with the phase separator system, including transfer lines, shall be above-ground. 
The phase separator system shall be capable of automatic shutdown for any of the following contingencies:

- High radiation in the separated organic.

- High-high level indication in the drain tank.

- Liquid indication in the enclosure sump/line encasement collection point.

- $\quad$ High liquid level in temporary holding tank.

The coalescer shall separate any emulsions created by the retrieval process into two streams, organic and aqueous. Minimum purity of organic discharged to the treatment system: less than $2 \%$ aqueous carryover.

- $\quad$ Material of coalescer element: corrosion and radiation resistant (e.g., glass fibers).

- Material of coalescer vessel: preferably 316 or $316 \mathrm{~L}$ austenitic stainless steel.

- Coalescer Flow capacity: $5 \mathrm{gal} / \mathrm{min}$ maximum.

- Coalescer operating pressure: 2 to 5 pounds per square-inch $\left(\mathrm{lb} / \mathrm{in}^{2}\right)$ (gauge) differential.

- Coalescer operating temperature: $25^{\circ} \mathrm{C}$ to $60^{\circ} \mathrm{C}$.

- $\quad$ System shall be flushable.

The separations enclosure shall be shielded to limit personnel exposure to no greater than $30 \mathrm{mR} / \mathrm{hr}$ or less.

Hardware Description:

The separations enclosure will consist of a two-compartment shielded box approximately $3 \mathrm{ft}$ by $6 \mathrm{ft}$ by $6 \mathrm{ft}$ high. The arrangement is similar to a common design used in plutonium operations. The cabinet design has an operating side and a maintenance side. Locating the maintenance side in a room separate from the operating side affects contamination control. The partition between the maintenance side and operating side of the cabinet serves as a radiation shield from expected high exposure items.

The partition wall in the separation enclosure serves a similar purpose, shielding the operator from the radiation emissions from the drain tank, coalescer, and filter. The operating side houses the pump, valves, and instrumentation, which are accessible for maintenance through removable panels. The extension rods for the valve handles pass through the operating side panel. The backside of the separation enclosure is sealed; the only access is through the lid. The radiation monitors are located on the operating side, one on the inlet and the other on the outlet of the coalescer. Other instrumentation in the operating compartment include the interface detector, liquid-level detectors, flowmeters, and the temperature element. An encased line will extend from the separations enclosure to the organic treatment system. 
The separations enclosure houses the aqueous-organic separation system that consists of the following:

- $\quad$ Pre-filters

- Coalescer

- $\quad$ Aqueous drain tank

- $\quad$ Aqueous return transfer pump.

The pre-filters remove particulate from the separation system inlet. The coalescer separates the organic and aqueous phases. The aqueous drain tank serves many functions including temporary storage of separated aqueous, aboveground system drain, separation enclosure sump, and flush tank. The aqueous return drain tank pump transfers the contents of the drain tank back to C-103.

The first component of this system is the pre-filters. The pre-filters prevent the particulates from plugging the coalescer. Three coalescer prefilters are provided, but only one pre-filter is on-line at a time. The sintered metal cartridges are rated for $5 \mu \mathrm{m}$ particles and the filter housing is drainable back through one of the other two filters.

The phase separator system will be equipped with radiation detection devices to ensure that highly radioactive solution is not pumped to the organic treatment system.

Instrumentation and controls will provide for automatic shutdown of the process for high radiation, leaks, and other important process central parameters.

The phase separator system will be designed to contain leaks in the piping containment and the separation enclosure.

A self-contained, stand-alone microprocessor handles the analog inputs and outputs, discrete inputs, and discrete outputs. The microprocessor controller is contained in a cabinet with the analog and discrete termination panels and signal conversion modules.

The separation enclosure instrumentation is primarily for monitoring and controlling the coalescer. The only control loop is associated with the coalescer. A level monitor instrument will be used to position the aqueous drain valve.

Radiation monitors fixed to the coalescer inlet pipe and the outlet pipe indicate the performance of the coalescer. The ionization chambers, which are shielded from background radiation, detect the level of radioactivity of the feed and the separated organic. The continuous online monitoring of the radioactivity in these streams provides the operator with immediate indication of the inability of the coalescer to effect a clean phase separation. A high level of detected radiation in the organic will actuate an interlock shutting down the skimmer pump.

There are two options for aqueous removal from the coalescer to C-103. As a back up, pumping is possible from the drain tank as follows: the aqueous draining from the coalescer accumulates in the drain tank until the liquid level reaches the high-level detector, which causes the switch to 
close, starting the drain tank pump. Transfer of aqueous waste continues until the pumping has lowered the liquid level to the low-level detector, which switches the pump off. The drain tank is also equipped with a high-high liquid level detector that is a backup to the high liquid level detector. If liquid in the drain tank should exceed the level that would normally cause the pump to start because the high level detector-switch system failed, then the high-high liquid level actuates an interlock that shuts down the skimmer pump.

A liquid detection probe is used to detect leakage into the separation enclosure sump. When contacted with any liquid solution, this probe actuates an interlock that shuts down the skimmer pump.

The coalescer performance is best at temperatures greater than $25^{\circ} \mathrm{C}$. A temperature device is mounted in the organic product line. The temperature of the $\mathrm{C}-103$ waste and the heat from the drain tank pump is expected to maintain the operating temperature of the coalescer above $25^{\circ} \mathrm{C}$. However, if winter operation is planned, unacceptably low system temperatures could occur. Manually adjusted electrical resistance heating of the coalescer is provided to increase the coalescer temperature to the optimum level.

The separation enclosure is made up of a heavy shielded section and a light shielded section. The components exposed to the highly radioactive aqueous solution (i.e., coalescer, filters, and the drain tank) are mounted in the heavily shielded section. The drain tank is fabricated with 1.5 -in thick plate for additional radiation protection. The lightly shielded section, containing the valving, radiation monitors, and instrumentation, is separated from the heavily shielded area by an additional shielding plate. Front removable access panels allow for equipment replacement and maintenance in the lightly shielded section only. Final thickness of the shielded plates will be determined during definitive design.

The separation enclosure will normally be sealed. All internal valves have extension rods connected through enclosure walls to external valve handles. Enclosure penetrations and nonwelded seams will be fitted either with a gasket, or packing glands. There will also be a vent line with a HEPA filter in it that goes back to the existing HEPA filter system at C-103 Riser 2.

Fluid entering the separation enclosure C-103 from Riser 2 flows through $1 / 2$ in, schedule 40 , double encased stainless steel pipe and is filtered through one of a bank of three $(5 \mu \mathrm{m})$ filters.

Local pressure indicators will be located at the inlet and outlet of the filters and the outlet of the coalescer. These indicators will help monitor the performance of the filters and the coalescer.

There will be a radiation detector and a flow measurement device at the inlet of the coalescer and another radiation detector, as well as temperature measurement device, at the outlet of the coalescer. The radiation detectors will be used to determine the adequacy of the organic separation. Radionuclides are more prevalent in the aqueous solution than they are in the organic solution. The inlet and outlet radiation readings can be compared to determine how the separation process is working. Based on the outlet radiation reading, the operator can decide to continue the transfer to the tank trailer or terminate it. High-level radiation readings will shut down the system. The temperature and flow measurement systems will be used to ensure the inlet flow and temperature is maintained for proper coalescer operation. 
Level instrumentation will monitor the level in the coalescer itself. Motor operated valves will be provided at the outlet and the drain lines of the coalescer for level control inside the coalescer.

\subsubsection{Assumptions}

The design of the phase separation system is based on the May, 1994 preliminary design (WHC-SD-WM-PLN-092).

- Laboratory testing of coalescer performance is valid.

\subsubsection{Interfaces}

The phase separation system is connected by encased lines to C-103 and to the organic treatment system. There are two encased lines from C-103: the discharge line from the skimmer pump to the enclosure and the aqueous return to the salt well riser, and one encased line connecting the coalescer to the trailer mounted container. A filtered vent line at the separation enclosure is connected to the existing charcoal filter system on the tank.

\subsubsection{Reserved}

\subsubsection{Work Scope}

The following activities are required to assure an effective phase separation system life cycle:

- Completion of studies on the optimum temperature and flow rate for coalescer operation.

- Completion of studies to determine the effect of foam formation and dispersion.

- Completion of studies to assure the test simulant adequately represents the organic to be processed.

- $\quad$ Perform filter system investigation on particle volumes, flushing requirement and plugging potential.

- Test procedure development.

- Readiness documentation development.

- Operating procedure development.

- $\quad$ Process testing and readiness performance.

- System operation.

- $\quad$ Equipment decontamination and disposal.

\subsection{ORGANIC TREATMENT}

\subsubsection{Description}

The objective of organic treatment is to decontaminate the retrieved C-103 organic in order to meet DOT shipping requirements and the WAC requirements of the disposal facility. If the phase separation system can remove enough radionuclide contamination, it is likely that organic 
treatment will not be required. As the organic is removed from the tank progressively from the top of the organic layer to the bottom of the organic layer, the most likely scenario is that the top layers of organic will be clean enough for shipping and not require washing. As the lower layers of organic are retrieved from the tank, though, more aqueous is expected to be entrained in the organic and thus require washing to meet shipping requirements.

In radioactive processes, organic solvents have typically been purified by two methods distillation, or by "washing" with an immiscible chemical solution. The solvents used at the PUREX and B Plants were mixtures of several organic compounds. These organic compounds are relatively nonvolatile and chemically stable at moderate temperatures. Therefore, chemical washing has proven to be a simple and effective treatment method for these materials.

Solvent decontamination by adsorption of contaminants on porous media is a more recent development. Laboratory studies have shown that certain macroreticular ion exchange resins are very effective in removing residual radioactivity from PUREX solvent. Assuming this method would work successfully with the $\mathrm{C}-103$ organic, an ion exchange system could be installed near the separation apparatus. The organic would be pumped through the system and into the interim storage tank or trailer transport tank. However, this method requires laboratory development with C-103 organic simulant, as well as scale-up data in order to pursue further design.

Alkaline wash is the first choice for treatment of the organic in C-103 because its effectiveness for a TBP-NPH mixture is well established. The success of this method has been demonstrated by its incorporation in the PUREX process. In addition, the PUREX organic inventory (sent for disposal after plant shutdown) treated by solvent washing met Low Specific Activity (LSA) requirements.

Based on initial laboratory testing with actual $\mathrm{C}-103$ waste samples, it has been determined that $0.1 \mathrm{M}$ sodium ethylenediaminetetraacetic acid (EDTA) at $\mathrm{pH} 11$ will reduce the organic radionuclide concentrations by approximately $95 \%$ after two washes (Lumetta, 1996). This should qualify the organic as LSA material.

The chemical washing process involves adding a chemical (alkaline or caustic) as an agent to effectively "wash" the radioactive constituents out of the organic. In this case, the EDTA will be used as a complexing agent to attach onto the radionuclides in the entrained aqueous, thereby removing them from the organic phase. The highly radioactive constituents, then, would remain in the wash solution and be disposed of through the aqueous return system, while the "cleaned" organic would be interim stored for offsite shipment and subsequent disposal.

\subsubsection{Operational Concept}

The items required for an effective organic treatment system include a phase disengager or decanter, a vessel for achieving intimate contact between the aqueous and organic phases, and up to two auxiliary vessels - one for temporary storage of the makeup wash solution and one for receiving the residual high- level waste solution from the decanter. The vessels should be equipped with samplers, agitation, heating/cooling capability, and specific gravity and temperature measurement instruments. In addition, pumps and jumpers will be required to transfer the solutions between tanks. Finally, a clean transport truck is required for interim 
storage of the cleaned organic pending final disposition. This is the preferred option to preclude recontaminating the organic.

\section{Contactor Vessel:}

The organic wash vessel must be capable of achieving intimate contact between the organic and aqueous phases. Any tank that is equipped with a high-efficiency, slow speed $[\sim 300$ revolutions per minute (rpm)] agitator will probably be capable of providing the necessary phase mixing. Since time is not of great importance (within reasonable limits), less efficient contacting can be compensated by longer contact time.

The size of the contactor is not critical, within reasonable limits. Any vessel in the size range of 1,500 to 5,000 gal, equipped with an efficient agitator should be adequate. A vessel smaller than (1,500 gal) would require an excessive number of small batches with the probability of higher "losses" of organic to aqueous waste. With larger vessels it would be more difficult to obtain intimate phase contact, particularly with agitators of limited size. An International Standards Organization (ISO) tank in the size range of 2,500 gal will be used.

At the B Plant, the required degree of cleanup of the organic solvent was accomplished with a recirculation pump and a standard propeller-type agitator in a standard (4,000 gal) vessel. This type of contactor performed satisfactorily under the process conditions at B Plant and should be satisfactory for cleaning the organic from $\mathrm{C}-103$.

\section{Decantor:}

An aqueous-organic decanter vessel will be required to obtain a good, clean separation of the phases after the treatment step. Preliminary studies with simulated aqueous waste and organic solutions indicate a relatively long disengaging time, therefore a horizontal box-type decanter with a large interfacial area, will be required. The approximate dimensions of the unit are $5 \mathrm{ft}$ long by 30 -in wide by 18 -in deep.

\section{Auxiliary Equipment:}

The installation of jumpers or other auxiliary equipment will be required in order to receive and treat the organic and separate the phases. Most, if not all, of the equipment changes can be accomplished by contact maintenance.

\section{Operating Sequence:}

The process flow diagram for organic treatment is shown in Figure 8.3.

First, the EDTA wash solution (approximately 1,000 gal) is added to the wash tank. The aqueous recirculation pump is started and the aqueous wash solution is circulated in the wash tank. The organic (and entrained aqueous) solution is pumped from the coalescer (phase separation system) to the wash tank. 
Figure 8-3. Organic Washing Process Flow Diagram

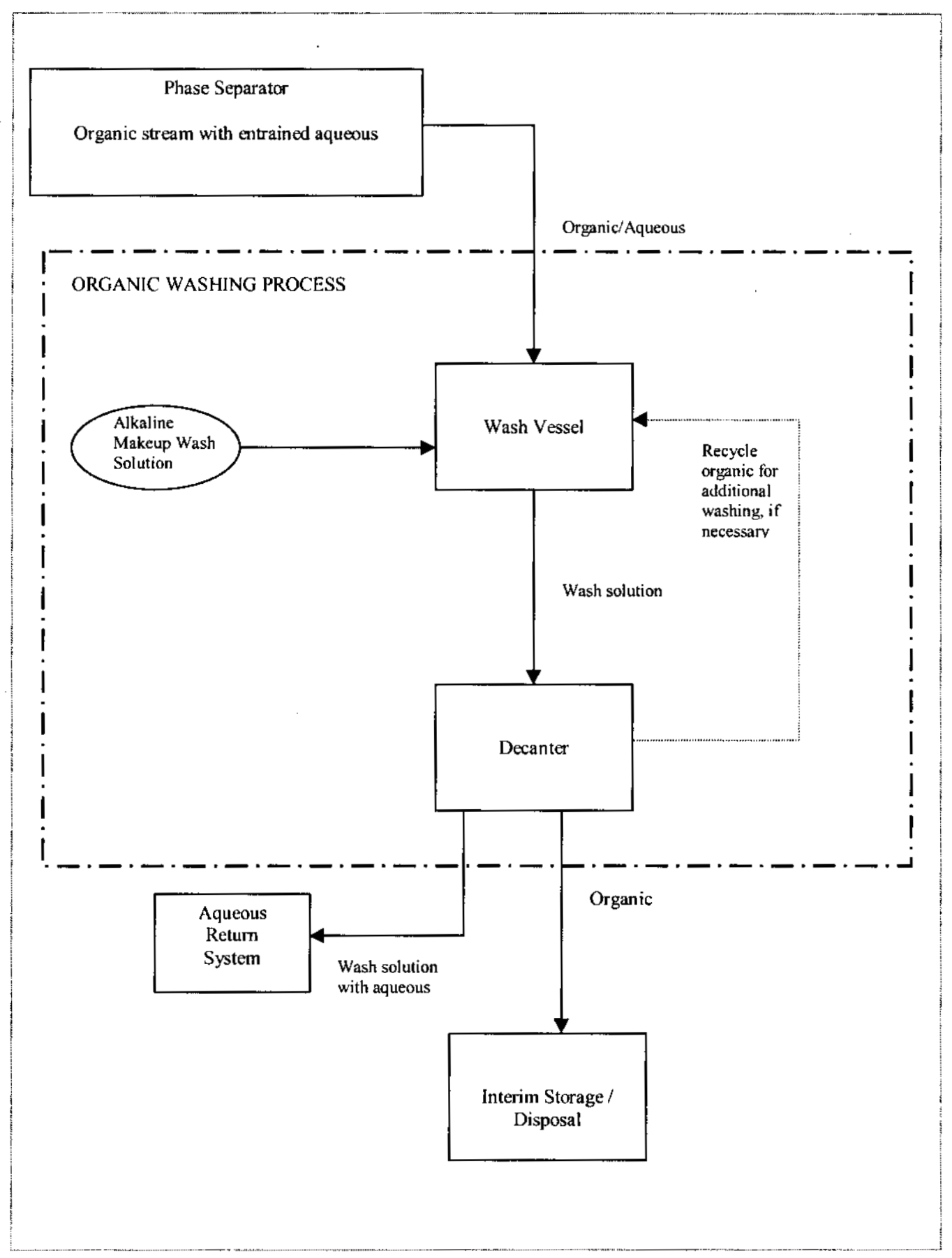

When a batch of organic (approximately 1,000 gal) is in the wash tank, the organic re-circulation pump is started and the organic is circulated along with the aqueous wash solution for at least two hours (as determined through laboratory development). 
The organic and wash solution is then allowed to settle in the wash tank for a period of time, as determined through laboratory development. Once phase disengagement has occurred, the wash solution is pumped out from the bottom of the tank via a bottom suction pump into an LR56/H cask truck, sampled (if required), and sent to the 204-AR Unloading Facility. Another option of sending the wash solution to $\mathrm{C}-103$ is discussed later.

The organic and any remaining wash solution in the wash vessel is then pumped to the decanter vessel where phase disengagement is allowed to continue until completion. Any additional wash solution is also pumped into an LR56/H cask truck for transfer to 204-AR. The organic is then sampled and analyses requested for gamma scan, ${ }^{90} \mathrm{Sr},{ }^{241} \mathrm{Am}$, and total Pu. Upon receipt of the sampling results, the organic is then either stored (temporarily) in the decanter or pumped to an ISO tanker for interim storage or into a transportation vessel for immediate shipment to the disposal facility. By sampling in the decanter vessel and determining the "cleanliness" of the organic, it can be assured that the ISO tanker will remain uncontaminated for shipment to the disposal facility.

\subsubsection{Hardware}

An unshielded portable tank will be required for use as the wash vessel. A standard ISO tank is approximately 605 centimeters $(\mathrm{cm})(238 \mathrm{in})$ long and has a maximum capacity of 24,000 liters (L) (6,300 gal). Pipe, valve, pump, decanter, and pipe connection panel supports will be added, as well as the standard propeller-type agitator. The ISO tank will be built to specification and skid-mounted next to the phase separation system at the C Farm.

Organic/aqueous from the coalescer will flow through piping to the ISO wash tank through an organic pump. A bottom suction pump on the wash tank will remove the disengaged wash solution from the tank to the LR56/H cask truck. The organic and remaining wash solution will flow through piping to the decanter. The dilute 0.1M EDTA solution will flow from the existing fixed dilute solution tanker truck through a pump to a nozzle on the wash tank. Vent gas and overflow liquid will flow through a third hose from/to a wash tank nozzle to the LR56/H cask truck. Electrical instrument power will be connected to a control panel for distribution to (1) the Resistance Temperature Detector (RTD) sensor in a wash tank nozzle, (2) the associated transmitter and indicator, and (3) the three differential pressure transducers, signal conditioners, and indicators associated with specific instruments.

The organic pump can recirculate organic liquid through the wash tank nozzle or the decanter. Foam fire suppression piping and a distribution nozzle will be installed above the wash tank location in the containment tent. This will serve for fire protection from combustion of the organic.

The decanter and pump capacity of $25 \mathrm{gal} / \mathrm{min}$ was selected to allow unloading the approximately $2,500 \mathrm{gal}$ load into the wash tank in two hours. The $1 \mathrm{hp}$ pump will produce a $26 \mathrm{psi}$ pressure rise and will self prime from $12 \mathrm{ft}$. This is assumed sufficient for the coalescer and the distribution manifold connected to the wash tank nozzle.

The decanter is of standard size of approximately 2,500 gal, fitted with a sight glass and sampling equipment. Upon receipt of favorable sampling results, "clean" organic will flow 
through piping from the decanter through a pump to an ISO tanker for interim storage or shipment to offsite disposal. The decanter will also have a bottom suction pump to remove any remaining wash solution to the LR56/H cask truck. Used wash solution will flow through piping from the decanter through a pump to the LR56/H cask truck.

The wash vessel and decanter will likely be sited at the same place as the phase separation equipment. The concrete pad will require a stainless steel liner with raised sides to provide secondary spill containment.

\subsubsection{Assumptions}

- Performance of the coalescer. Effective coalescer performance does not rule out the need for additional organic decontamination.

- Radiation survey of the organic stream after the phase separation process will help to determine the amount of aqueous carryover in the organic stream.

- The treated organic shall qualify for shipment as an LSA material as defined by current regulations or as acceptable by the disposal receiving facility, whichever is limiting.

- The dose rate of the organic after the washing process will be such that interim storage and transportation to the disposal facility can take place in an unshielded tank.

\subsubsection{Interfaces}

The organic treatment process will receive organic with entrained aqueous from the phase separation process. The organic treatment process will provide "cleaned" organic for interim storage (as necessary) prior to offsite treatment and disposal as well as aqueous (removed from the organic) and "used" wash solution routed to the 204-AR Unloading Facility. In addition, the organic treatment process will require support from Site Utilities (power, decontamination solution, water, fresh air, etc), and laboratory support for the makeup of the EDTA wash solution.

\subsubsection{Reserved}

\subsubsection{Work Scope}

The following activities are required to assure an effective chemical washing process:

- Completion of laboratory development for the optimization of the chemical washing process. At this time, a ratio of 1:1 has been used effectively to show that chemical washing of the organic can be effected. Optimization of the process will involve varying the ratio of wash solution to simulated organic, varying the temperature, and varying the contact and disengaging time.

- Preparation of conceptual design of the chemical wash.

- Test procedure development. 
- $\quad$ Readiness documentation development.

- $\quad$ Operating procedure development

- $\quad$ Process testing and readiness assessment.

- Organic treatment through washing of the organic with EDTA.

- $\quad$ Pump cleaned and sampled organic to the receiving tank.

- $\quad$ Move the receiving tank to permitted interim storage.

- $\quad$ Equipment decontamination and disposal.

\subsection{AQUEOUS RETURN}

\subsubsection{Description}

The aqueous return system for the organic treatment solution is the LR-56 cask system. After organic treatment and after the treatment solution has settled, it will be "vacuum loaded" into the LR-56. Once the LR-56 is full, the treatment solution will be transported to the 204-AR facility where it will be "vacuum unloaded". From the 204-AR facility, the organic treatment solution will be pumped to a double shell tank in east area.

Another wash solution aqueous return concept is to drain/pump the treatment wash water directly to $\mathrm{C}-103$ using the same under the surface drop leg as the coalescer. This option reduces operational complexity and cost but creates two potential issues, one is that "newly generated waste" is going to a SST and the other is will this water addition affect skimmer operation. The baseline in this report is to use the LR-56 and transfer the wash solution to a DST via 204-AR.

\subsubsection{Operational Concept}

The LR-56 is a self contained transport system and as such has all of the pumping, piping, controls and interlocks necessary to transport the organic treatment solution from the organic treatment system to the 204-AR facility. One drawback of the LR-56 is that it has a capacity of approximately 1000 gallons, therefore, transport of the organic treatment solution to the 204-AR facility may require several cycles.

It is anticipated that the pumping of the organic treatment solution will be performed using the "vacuum loading" and "vacuum unloading" modes of the LR-56. Using these modes will place all piping under a negative pressure, therefore, there will be no possibility of leakage.

The 204-AR facility operates and maintains the LR-56. Currently, operator training is ongoing and startup activities are proceeding to be able to operate the LR-56 in the very near future. 


\subsubsection{Hardware}

The LR-56 is a complex shielded tanker with a liquid capacity of 4,000 L (1,057 gal) and incorporates $35 \mathrm{~mm}$ (1.4 in.) of lead shielding. The packaging was designed and manufactured in France and is certified in that country to transport Type B quantities of liquid. The RPP has procured a LR56, which is available for use. At Hanford, the shipment of C-103 waste using LR56 within site boundaries is authorized by an onsite Safety Analysis Report for Packaging (SARP) (WHC-SD-TP-SARP-009). The LR56 is new and has not been radioactively contaminated, however, it is planned to be put in to service in the very near future.

\subsubsection{Assumptions}

The organic treatment solution will be compatible with the 204-AR facility and double shell tank wastes.

\subsubsection{Interfaces}

The aqueous return system (LR-56) must interface with the organic treatment system and the 204-AR facility. Scheduling of the LR-56 will need to be coordinated with other user projects.

\subsubsection{Reserved}

\subsubsection{Work Scope}

- Readiness documentation development.

- $\quad$ Operating procedure development.

- Transfer and offload wash water at 204-AR.

- $\quad$ Flush LR56 system for future use.

\subsection{INTERIM ORGANIC STORAGE}

\subsubsection{Description}

Interim storage may be required upon completion of organic treatment, prior to offsite shipment to the disposal facility, due to scheduling conflicts or other unanticipated delays in offsite shipping. If at all possible, immediate shipping of the clean organic will be the preferred in C103 organic removal process.

\subsubsection{Operational Concept}

The purpose of interim storage is simply to store the organic in a tank until the organic can be shipped offsite to a disposal facility. Pumping of the organic into the tank is covered Section 8.3, Organic Treatment, and offloading of the tank and/or its contents for vendor shipment is covered in Section 8.6, Disposal/Destruction Site. 


\subsubsection{Hardware}

An unshielded portable tank will be required for use as the interim storage vessel. A standard ISO tank fits within a $605 \mathrm{~cm}$ (long) by $259 \mathrm{~cm}$ (wide) by $244 \mathrm{~cm}$ (high) (238- by 102- by 96-in) frame. The maximum capacity of such a tank is $24,000 \mathrm{~L}(6,300 \mathrm{gal})$.

The interim storage will be sited most likely at the $\mathrm{C}$ Farm on a concrete pad. A regulatory compliant storage pad design has been developed and storage location is dependent on access and dose rate (McClure, 1999).

\subsubsection{Assumptions}

The dose rate of organic will be such that interim storage can take place in an unshielded tank.

\subsubsection{Interfaces}

The interim storage process will receive "cleaned" organic that has been verified through sampling from the organic treatment process (or the phase separation process if organic treatment is deemed unnecessary). The interim storage process will provide an ISO tank containing the organic ready for shipment offsite in the same tank or for unloading into a vendor's tank.

\subsubsection{Reserved}

\subsubsection{Work Scope}

The following activities are required to assure effective interim storage:

- Tank construction and sitting.

- Readiness documentation development.

- Operating, surveillance, and emergency response procedure development.

- Acceptance and storage of the cleaned and sampled organic.

- Transfer to stripping vehicle.

- Tank clean-up for reuse.

\subsection{DISPOSAL /DESTRUCTION SITE (INCLUDES TRANSPORT CAPABILITY)}

\subsubsection{Description}

Transporting C-103 organic phase liquid to a site for disposal by incineration is an effective disposal method (Dukelow, 1996). The type of shipping container is dependent upon the volume to be transported, the radionuclide concentration DOT regulations, and the WAC of the receiving disposal facility. 
This is based on the concentration of radionuclides in the organic phase and the Waste Acceptance Criteria (WAC) of the receiving incineration facility. Diversified Scientific Services, Inc. (DSSI) of Kingston, Tennessee (currently), and Allied Technical Group of Richland (ATG), Washington (scheduled to accept waste by September, 2000), and TSCA Incinerator (TSCAI) of Oak Ridge, Tennessee each operate an incinerator that can accommodate the contaminated separable organic phase of $\mathrm{C}-103$. No disposal costs for ATG are available at this time.

Offsite land disposal at the Nevada Test Site (NTS) is an additional option that recently became available. Fluid Tech, Inc. of Las Vegas, Nevada, will perform stabilization of the liquid organic waste shipped in overpacked 55-gal drums, provided the radionuclide concentration meets the WAC for NTS. While preliminary evaluation has indicated this is a viable disposal option, the remainder of this section uses incineration as the baseline.

\subsubsection{Operational Concept}

Before the waste can be accepted, the radionuclide concentration must be within the prescribed limits of the facility WAC. The analysis (Lumetta, 1996) indicates that activity of radionuclide species are within the allowable limits prescribed in the DSSI in the untreated organic phase liquid.. However the ${ }^{90} \mathrm{Sr}$ concentration exceeds the ATG WAC by a factor of 7 (see Appendix $A$, Tables A-1 and A-2). If subsequent analyses of the C-103 organic phase liquid are in accordance with the 1996 results, then EDTA treatment to reduce radionuclide concentrations is not required to meet the DSSI WAC. However, it is expected that the total volume of organic phase liquid removed by the skimming process will contain approximately $0.2 \%$ aqueous phase with a high concentration of radionuclides. As a result, it is likely that the radionuclide concentration of the organic phase liquid will increase. If the increase exceeds the WAC of the receiving facility, then treatment and phase separation will be necessary.

If DSSI incinerates the waste, they will be responsible for disposal of the ash. In addition, DSSI is exploring disposal options other than incineration for this C-103 waste stream in an effort to reduce disposal cost.

Tables A-1 identifies each radionuclide species, the concentration and total amounts of radionuclides in untreated organic phase, and the maximum allowable by DSSI. The untreated C-103 organic phase liquid could fail to meet the requirements of the DSSI WAC for ${ }^{90} \mathrm{Sr}$, as that radionuclide is less than an order of magnitude less than the WAC limit.

\section{Transportation Requirements}

It appears that the untreated C-103 organic phase will qualify as LSA-II waste in accordance with 49 CFR 173.433 (Appendix A). Although the untreated concentrations of radionuclides are within the allowable shipping limits for LSA-II radioactive waste, the skimming process could elevate the radionuclide levels. Sampling after skimming and phase separation will be necessary to determine if further treatment is needed to reduce the levels to within the LSA-II limits.

There are two shipping container options. A 7,700 gal ISO tank and the DSSI disposal facility can provide a 4,800 gal liquid tanker that is permitted to transport LSA-II wastes. 


\section{Transportation Cost}

The transportation cost of the $\mathrm{C}-103$ waste by bulk liquid tanker or containerized waste on a flatbed truck, is normally based on round-trip mileage. The average rate of $\$ 1.50$ per mile for the approximately 4,800 -mile round trip to DSSI is approximately $\$ 7,200$. The advantage of the International Standards Organization (ISO)/flatbed system over the bulk liquid tanker is that the waste could be transported in one load with the ISO system as opposed to two loads with the tanker. Using multiple shipping vessels could result in more waste generated through decontamination at the transfer pad.

\section{Analysis Cost}

The analysis of the organic phase liquid will be sent to Waste Management Technical Services (WMTS) for evaluation and final determination of the offsite shipping classification. WMTS will make arrangements for offsite shipping including arranging for suitable shipping container, container inspection, mode of transportation, and completion of all shipping documentation. The cost for this service is estimated at $\$ 1,000$.

\section{Disposal Cost}

Cost for disposal of the C-103 organic phase liquid by DSSI is estimated to be approximately $\$ 1.6$ million for the estimated 5,000 gal of organic phase liquid. The cost driver is the high concentration of TBP.

\subsubsection{Hardware}

The hardware under consideration for transportation consists of a vendor-supplied bulk liquid tanker and an ISO tank flat-bed truck. DSSI has a 4,800 gallon bulk liquid tanker permitted to transport LSA-II liquids over the highway. If, as a result of the skimming process, the activity of the organic phase increase to above the LSA-II limit, the tanker may not be used to transport the C-103 organic phase liquid.

A flatbed truck can be used to transport an ISO tank containing the C-103 organic phase when the organic phase meets shipping and WAC requirements. The advantage of the ISO tank over the tanker is that no additional tank needs to be obtained to treat the skimmed organic phase liquid from C-103. The tank is skid-mounted ISO tank and can be placed on a flatbed truck to transport the waste to the disposal facility. If however, no treatment is necessary, less expensive options may be more attractive. DSSI will provide the bulk liquid tanker at no cost for waste shipped to their facility. An ISO tank already on the Hanford Site might be used at no cost, otherwise one would have to be purchased.

\subsubsection{Assumptions}

The main assumption is that after phase separation and treatment, the $\mathrm{C}-103$ separable organic phase liquid will meet the WAC requirements of the receiving disposal facility and DOT shipping requirements as LSA-II. Thus, the organic phase may be transported in one or two shipments. 
Since the DSSI bulk liquid tanker is dedicated only to transporting LSA-II material, the tanker will carry residual radioactive contamination after rinsing at the disposal site. It is assumed that the residual activity will not increase the total activity of the containerized separated/treated C-103 organic phase liquid of the containerized treated/separated C-103 organic phase liquid to levels above the LSA-II limits. If the activity of the tanker is too high, then the organic phase liquid may need to be treated/further treated to reduce activity levels low enough so that the combination of tanker residual and organic phase liquid do not exceed the LSA-II limits.

\subsubsection{Interfaces}

Transportation will interface with Interim Storage, the Waste Transfer Pad, onsite Solid and Radioactive Waste Disposal Facility, onsite Facilities, and offsite Disposal facility.

\section{Interim Storage}

After the phase separation and wash phase, the organic phase liquid will be placed in an interim storage vessel. The liquid needs to be sampled and analyzed for radioactive contamination to comply with DOT shipping (Tables A-3 and A-4) and disposal facility requirements (Table A-1). In addition, a pumping system to transfer the separated organic phase liquid to the tank/tanker for transportation needs to be compatible with the transportation vessel.

\section{Load In/Load Out Station}

If a bulk liquid tanker is used to transport the $\mathrm{C}-103$ organic phase liquid, a transfer pad will need to be constructed to transfer the washed $\mathrm{C}-103$ organic phase liquid from the holding tank to the tanker. The pad needs to be constructed to accommodate decontamination of the transportation vessel if needed. If an ISO tank is used to contain the organic phase liquid during interim storage, then facilities must be provided to move the tank from its interim storage location to a transfer pad, and to place the tank onto a flatbed truck for transportation to the disposal facility.

\section{$\underline{\text { Solid and Radioactive Waste Disposal }}$}

Decontamination of the vessel after transfer needs to be performed and provisions made to analyze and dispose of the decontamination solution. Thus, the transfer pad needs to be constructed to contain potential decontamination fluids.

\section{Site Facilities}

Electrical power as well as and water for decontamination of the transportation vessel and waste transfer equipment decontamination need to be provided.

Offsite Disposal facility.

The waste will be shipped in bulk liquid form to a disposal facility, DSSI in Kingston, Tennessee. 


\subsubsection{Reserved}

\subsubsection{Work Scope}

- Receive separable organic phase liquid with no aqueous phase at the load-out station.

- The organic liquid is pumped into one ISO tank, or in a bulk liquid tanker provided by the incineration vendor. Two loads in the tanker will be necessary to transport all the suspected volume of organic phase liquid.

- $\quad$ Shipping container/transporting vehicle are decontaminated as necessary.

- Load-out station is removed and all materials disposed in accordance with Site requirements.

- If an ISO tank is used to transport the waste, then the ISO tank will be returned to the Site, decontaminated as necessary and stored.

\subsection{REGULATORY, PERMIT AND AUTHORIZATION BASIS CHANGES}

\subsection{Introduction}

The methods and processes for the removal, treatment, storage, and disposal of separable organic from C-103 involve processes that have been investigated and documented in several previous studies. Any time new or modified processes are to be employed in RPP facilities an assessment of the potential regulatory impacts on the RPP Authorization Basis (AB) needs to be performed. Based upon the results of such an assessment the following regulatory, permit and/or Authorization Basis changes may be required:

- Hanford facility Dangerous Waste Part A Permit modification,

- Air permit review and Notice of Construction issuance,

- $\quad$ National Environmental Policy Act (NEPA) impacts and updates for organic treatment other than phase separation,

- $\quad$ RPP Final Safety Analysis Report (FSAR) Amendment or Justification for Continued Operation (JCO) preparation,

- $\quad$ Safety Analysis Report for Packaging (SARP) for transportation of organic to disposal location/facility.

\subsection{Assessment Methodology}

The assessment of $\mathrm{AB}$ impacts on the $\mathrm{C}-103$ separable organic treatment/disposal is initiated through the Unreviewed Safety Question (USQ) process (CHGI, 1999). The USQ process exists to allow contractors to make physical and procedural changes and conduct tests and experiments without prior DOE approval as long as the changes do not explicitly or implicitly affect the $\mathrm{AB}$ 
of the facility or result in a change to Technical Safety Requirements (TSRs). If the equipment and processes involved in the removal, treatment, storage, and disposal of the separable organic layer from $\mathrm{C}-103$ are deemed to be a modification of existing systems, and are bounded by the accident analysis in the RPP FSAR, then utilization of the USQ process is appropriate. This process begins with a USQ Screening to determine whether a USQ Evaluation is required. For the removal/treatment/disposal of C-103 separable organic there are enough unanswered regulatory and $\mathrm{AB}$ questions to require the performance of a detailed USQ Evaluation. To determine if this project is within (or covered by) the current RPP FSAR it will probably be necessary to perform some analyses and calculations to demonstrate compliance. If there is a positive USQ determination a RPP FSAR Amendment (or JCO) will need to be prepared to modify the AB. These issues are discussed in Section 9.3 below.

The regulatory and permit impacts must also be assessed and recommendations provided for the disposition of the issues regarding Ecology Air Permits and NOC issuance, NEPA impacts, modifications to the Dangerous Waste Part A Permit, and other state and federal permits. These issues are discussed in Section 9.4 below.

The shipment of separable organic offsite for storage/disposal may be impacted by the type of shipping container selected, chemical composition of the material, activity concentration in the organics, shipping volume, and total activity shipped. The onsite shipment of the aqueous return also has shipping requirements which must be met. Both types of shipments require an analysis of the potential impacts of accidents and abnormal events, and an assessment of the ability to meet DOE and DOT shipping requirements. These analyses are typically contained within a Safety Analysis Report for Packaging (SARP). A discussion on the status of the shipping options is contained in Section 9.5 below.

\subsection{Authorization Basis Modifications}

Based upon a review of the $\mathrm{C}-103$ separable organic removal/disposal processes being recommended, the following assumptions and initial conclusions/recommendations have been developed.

1. Performance of a USQ Screening will result in a positive finding (i.e., a USQ Evaluation will be required).

2. There is a likelihood that a USQ determination will be negative. The equipment being proposed could be classified as waste transfer equipment and processes in relation to the FSAR and TSR documents. In addition, the expected radionuclide concentrations and inventories are orders of magnitude below the aqueous tank wastes which are normally involved in waste transfers. Consequently, any potential accident scenarios associated with this process should be adequately bounded by the following FSAR Evaluation Basis Accidents:

- $\quad$ Section 3.4.2.4 - Organic Solvent Fire,

- $\quad$ Section 3.4.2.5 - In-Tank Fuel Fire/Deflagration, 
- $\quad$ Section 3.4.2.7 - Surface Leak Resulting in Pool, and

- $\quad$ Section 3.4.2.9 - Spray Leak in Structure or from Waste Transfer Lines.

However, there are issues on the toxic consequences and whether there is more solvent burnt in a glovebox organic solvent fire than the in tank fire.

3. It is estimated that a USQ Evaluation and the accompanying analysis could take up to two months and cost around $\$ 20 \mathrm{~K}$ to $\$ 30 \mathrm{~K}$.

4. Although it may be possible to close the AB modification issue with a negative USQ Evaluation, it is considered prudent to budget for the preparation of a RPP FSAR Amendment package. A SAR Amendment package typically requires detailed facility/process descriptions; hazards and accident analyses; determination of safety Systems, Structures, and Components (SSCs); and identification of potential TSR requirements. Preparation of a SAR Amendment package could cost between $\$ 200 \mathrm{~K}$ and $\$ 300 \mathrm{~K}$, and require three months or more. The total time from initiation of the amendment process through the approval cycle is typically 6 months.

5. For planning purposes this scoping study will assume that a SAR Amendment package will be required at a cost of $\$ 200 \mathrm{~K}$ and a duration of 6 months from start through DOE approval.

\subsection{Permits, NOCs, and NEPA Impacts}

The Environmental Permits, Approvals, and Requirements (EReqs) Checklist is a general purpose tool for identifying environmental standards and determining their applicability to Hanford Site work. The EReqs Checklist is updated as necessary to account for new or changed federal and state regulations, significant permit and approval conditions, and other relevant environmental mandates. Assessments of permitting needs for RPP projects are performed by a representative from RPP Environmental Services. K. S. Tollefson prepared an EReqs Checklist (Table C-1) and a RCRA and Operational Monitoring estimate (Table C-2) for the C-103 separable organic removal/disposal scoping study. These tables are contained in Appendix $\mathrm{C}$ of this document.

\subsection{Transportation SARP}

Results of initial analyses on untreated C-103 organic phase liquid indicates that this material should qualify as LSA-II waste in accordance with DOT regulations contained in 49 CFR 173.433. With the assumption that the organic liquid meets LSA-II, the determination of a recommended transportation vessel depends on the disposal location and the total cost associated with the transportation options. At this time there appear to be four shipping tanks/vessels which are under consideration: 1) LR56/H cask; 2) a standard ISO tank; 3) an extended ISO tank; and 4) a bulk liquid tanker owned by DSSI. Of these four vessels both the standard ISO tank and the DSSI bulk liquid tanker have current SARPs which should need no modifications to transport the $\mathrm{C}-103$ organic offsite. 
1. The Hanford Site LR56/H cask was manufactured and certified in France to that country's transportation standards. If this cask is selected for offsite use of LSA-II material, it will probably require an evaluation by Waste Management personnel to determine compliance with DOE and DOT requirements and the preparation of the necessary transportation documentation. This is estimated to cost less than $\$ 5 \mathrm{~K}$.

2. The standard ISO tank which is currently on the Hanford Site may require an evaluation by Waste Management personnel to determine compliance with DOE and DOT requirements and the preparation of the necessary transportation documentation. This is estimated to cost $\$ 5 \mathrm{~K}$.

3. To be used for transport of C-103 organic, an extended ISO tank would have to be designed, procured, and may require development of a transportation SARP. The combined cost for all these services has been estimated at $\$ 250 \mathrm{~K}$. The additional shipping volume obtained with this tank does not justify the additional costs associated with this tank.

4. The DSSI bulk liquid tanker is owned by DSSI and will be loaned to the C-103 organic removal project at no cost if the waste is shipped to DSSI for disposal. All necessary certifications and paperwork will be provided.

Based upon the lack of any significant added costs associated with compliance to DOT and DOE transportation requirements, it is recommended that the $\mathrm{LR} 56 / \mathrm{H}$, the standard ISO tank, or the DSSI bulk liquid tanker be utilized for the transport of the C-103 organic to the storage/disposal site.

It has been assumed that the aqueous which has been separated by washing the organic with EDTA solution can not be returned to C-103, but rather must be sent to a double shell tank (DST). This transfer to a DST can be accomplished by the use of the LR56/H cask. This cask is designed for the transport of Type $B$ quantities of radioactive materials, and has a current SARP which covers such shipment within the Hanford site. The transportation documentation necessary to authorize such shipments is expected to cost about $\$ 5 \mathrm{~K}$.

\subsection{STARTUP, TESTING AND READINESS STRATEGY}

The Startup strategy would follow the RPP Acceptance for Beneficial Use (ABU) process for the turnover of equipment necessary for the removal, treatment, and transfer to a mobile tank of the organic layer from Tank 241-C-103. This assumes these steps would be conducted by plant forces.

The startup strategy for the transportation and disposal of the organic layer to the off-site vendor would be developed and conducted under the off-site vendor's requirements [e.g., Safety Analysis Report for Packaging (SARP) and WAC]. A Startup Plan will be prepared and approved by RPP.

The testing strategy would follow the RPP processes for acceptance testing (e.g., Factory/ Construction testing) and operating testing (e.g., Performance testing). Performance Testing will be accomplished in two phases: 1) a cold Operational Demonstration on a bench scale to test the 
skimmer pump and separations equipment and 2) a final test in the field with all in place equipment, including the mobile tank. A Test Plan and procedures will be developed and approved by RPP. Within the Test Plan, an Operational Demonstration Plan will be prepared with all relevant performance and acceptance criteria. The conduct of the Operational Demonstration, and the completed Operational Demonstration Final Report will become the performance review of the ORR.

The readiness strategy will be an Operational Readiness Review (ORR) with compliance to DOE Order 425.1 and respective ORP and RPP procedures. The conduct of an ORR assumes Authorization Basis (i.e., accident analysis) changes will be required for the removal and treatment of the $\mathrm{C}-103$ organic layer. It is also assumed that there will be vendor readiness requirements for the input of the organic layer into the mobile unit, which would be included in the ORR. It is further assumed that the transportation and disposal safety/readiness requirements will be covered under the SARP. Therefore, any costs for the vendorDs readiness for the transportation and disposal of the organic are in their cost estimates. A Plant Readiness Plan, an ORR Plan of Action, and an ORR Implementation Plan with Criteria Review Approaches (CRA) will be prepared and approved by RPP and ORP. The completed ABU and Operational Demonstration Final Report will be an integral part of the ORR. Completed CRA documents with attached affidavits, the Final ORR Report, and Declaration of Readiness letter will be transmitted to ORP for their review and judgement. This strategy assumes ORP and contractor will conduct their Independent Overview during the plant ORR.

\subsection{ORGANIC POLISHING STRATEGY}

Organic polishing involves the remaining organic left in C-103 after bulk removal by the skimmer. The skimmer will leave behind about an $1.5-\mathrm{mm}$ layer of organic on top of the aqueous waste. The $1.5-\mathrm{mm}$ layer corresponds to approximately 200 to $600 \mathrm{~L}$ (50 to $150 \mathrm{gal}$ ) of organic. This thin layer is assumed to be discontinuous over the top of the waste, with "puddling" in some areas, and just a sheen in other areas. Removal of this remaining organic may be required to meet commitments for interim stabilization of C-103 and the no-visibleorganic-phase specifications of the Privatization contract.

Four alternatives are provided here as options for organic polishing. They are: 1) no action, 2) in-situ treatment, 3) global system, and 4) in-line treatment system. Each option is briefly discussed in the following paragraphs and either accepted or rejected based on preliminary evaluations.

The "no action" alternative leaves the sheen layer of organic in the tank after skimming. The remaining organic, then, would be saltwell pumped along with the supernatant. Since the saltwell pumping will take place at the bottom of the tank, the organic would be among the last of the liquid to be pumped from the tank. A study completed by CHG Process Engineering indicates that this would not create a unique situation. There is no additional cost for this alternative, as nothing will be done as far as organic polishing in this organic removal system.

The in-situ treatment alternative involves treatment of the organic sheen within the confines of the tank. The most reasonable alternative would be to add an absorbent to the tank to clean up the organic. This alternative was removed from consideration for cleaning up the bulk organic 
due to the larger volume of the bulk organic. In addition, once an absorbent was placed in the tank, there were questions as to how to remove the solid material. The concept presented here does use an absorbent to bind the organic, but the absorbent is contained within a mesh container that will allow its removal from the tank and disposal as hazardous waste. This option was considered most feasible and will be further evaluated for this scoping study.

The global system alternative involves a treatment system at the pretreatment facility where all the tank system waste will pass through prior to vitrification. The global system is based on the increasing evidence that there are about $87,000 \mathrm{~L}(23,000 \mathrm{gal})$ of process organic still present in the Hanford Site waste tank system (Dukelow, 1996). Therefore, it is likely that an organic pretreatment system will be required at the front end of the vitrification facility. The global system would not be a part of the organic removal system for C-103, and therefore will not be considered further in this study. Such a system will likely be required if a zero separable organic specification continues for Extend Phase I or Phase II vitrification operations.

The in-line treatment system involves treating the remaining organic as it is pumped with the supernatant from the waste tank through an absorbent bed located in a shielded enclosure outside the tank. The supernatant is expected to contain solids along with other contaminants that may be captured in the absorbent bed, thus preventing the absorbent from capturing and removing the organic from the waste stream. This option may be feasible if the filtering system can be designed to capture only the organic and not any other contaminants. Another result of this inline treatment system would allow the supernatant to settle at a DCRT and then pump out the bottom portion of the waste. However, disengaging time could be long and with the amount of organic remaining, the organic/aqueous interface could be difficult to determine. Using a selfcontained absorbent at this point in time may work (based on the concept presented for the insitu treatment option); however, no DCRT is available with the deactivation of CR vault. This option will not be discussed in this study.

\subsection{Description}

In-situ treatment of the remaining organic in C-103 seems to be the most feasible option when considering the relatively small amount of organic. The in-situ treatment will minimize contamination of the tank solids and waste transfer lines by the organic, and mixing of the aqueous and organic phases (with saltwell pumping) will reduce the amount of organic entrained in the aqueous.

The use of an absorbent for the removal of hydrocarbons from aqueous phases has been widely used in the oil industry for oil spill recovery operations. Many companies are using a variety of media as absorbents, from cellulose to activated carbon to polymers. The concept presented here is a hydrocarbon recovery system based on innovative polymer technologies by AbTech Industries of Scottsdale, Arizona. This technology consists of a proprietary blend of polymers called the OARS Smart Sponge ${ }^{\mathrm{TM}}$ that is chemically selective to hydrocarbons. It readily encapsulates the organic and bonds it within the structure. The process transforms the liquid waste into a manageable solid, repels water and remains completely buoyant for easy retrieval even when fully saturated. 


\subsection{Operational Concept}

The Light Duty Utility Arm (LDUA) would be used to move the absorbent into and out of the tank, as well as move the absorbent around in the tank to contact the organic. The absorbent is contained within a flexible mesh container that can fit well within the 12 -in riser on the tank. The container is lowered into the tank and moved around the surface of the tank using the LDUA. The LDUA would potentially have to be positioned in several risers to remove most of the organic. Once saturated, the container would be removed from the tank through the 12-in riser and the mesh container holding the organic-saturated polymer would be disposed of through the Hanford Site Solid Waste program.

\subsection{Hardware}

\section{Light Duty Utility Arm (LDUA):}

The LDUA is a mobile robotic system that can deploy other tools inside underground waste tanks. These tools are instrumental in retrieval, surveillance, confined sluicing, inspection, and waste analysis. The system contains 1) a flexible and adaptive robotic arm that can be positioned in tanks through the small tank openings (called risers), 2) a telescoping deployment housing, 3) a deployment vehicle, 4) an operations trailer, and 5) various tools called end effectors. The end effectors can be deployed at multiple elevations and positions within the tank. The end effectors for the LDUA include sensors to measure physical properties of tank waste. The LDUA has a radial reach of at least $13.5 \mathrm{ft}$ from the tank riser centerline. The deployment mast extends to at least $62.5 \mathrm{ft}$ to access the full depth of the tank.

\section{OARS Smart Sponge ${ }^{\mathrm{TM}}$ Propellets for Surface Skimming:}

OARS Propellets are non-leaching absorbent units, cylindrical in shape and approximately 2.5-in in length. The Propellets have a rough exterior and a very high internal surface area. OARS Propellets are packaged in flexible mesh containers and are designed to remove floating hydrocarbons, including sheen, from aqueous surfaces. Packaged OARS Propellets float on the surface and work equally well in calm or agitated environments.

\section{Disposal:}

Disposal of the organic-saturated OARS Propellets would be handled through the Solid Waste program. The OARS Propellets by themselves are recyclable, and therefore would become a waste based upon the waste classification of the hydrocarbon that it encapsulates.

\subsection{Assumptions}

One important assumption is that the absorbent material used for the in-situ treatment will indeed encapsulate and remove the organic from $\mathrm{C}-103$. AbTech Industries is confident that the NPH will be absorbed by the polymer without any problem. The TBP, however, was questionable due to its larger size. AbTech did do a preliminary laboratory evaluation with TBP and its polymer and found the ratio of polymer to TBP required to absorb the TBP. Further evaluation with C103 simulant is required, though, to determine if anything else in the solution will affect the absorption capability of the polymer absorbent. (AbTech 2000). 


\subsection{Interfaces}

The in-situ tank treatment will interface with tank farm operations in the mobilization of the LDUA to lower the absorbent container into C-103, move the absorbent container around the tank, and then raise the absorbent container out of the tank for disposal. Interfaces with Site Utilities will be needed for water, power, radiation monitoring, etc. An interface with Hanford Site Solid Waste will be required to dispose of the organic-saturated OARS Propellets according to its hazard classification.

\subsection{Reserved}

\subsection{Work Scope}

The following activities are required to assure an effective organic polishing system life cycle.

- $\quad$ Further evaluation of absorbents to polish tank organic. How the absorbent will work with actual or simulant C-103 organic. Will the absorbent capture all the organic and what else (radionuclides and other contaminants) will it also capture?

- Laboratory development of polymer absorbent with C-103 simulant.

- $\quad$ Test procedure development.

- Readiness documentation development.

- $\quad$ Operating procedure development.

- $\quad$ Process testing and readiness performance.

- Deploy LDUA and remote organic.

- $\quad$ Equipment decontamination.

- Material disposal.

\subsection{RISK MANAGEMENT}

There are several technical risk associated with this scoping study.

Risk 1: Existing facility and plant structure will be able to support the utility and equipment needs for $\mathrm{C}-103$ processing.

Risk 2: Current C-103 sample analysis/contamination levels do not change during processing.

Risk 3: Recovered organic material may require additional treatment beyond washing to meet shipping an/or disposal site requirements. 
Risk 4: Passive ventilation mode for the tank and new installations will be acceptable during processing operations and system flushing and decontamination.

Risk 5: Separated aqueous phase and the organic wash solution will be returned to existing tank farm systems without treatment or sampling.

Risk 6: There is no numerical endpoint criteria for the C-103 polishing step.

Risk 7: Previous testing performed primarily to select and validate concepts and verify performance for application of these systems is valid. An alternate weir flap material is available. Washing ratio of $1: 1$ is acceptable.

Risk 8: The treated organic shall qualify for shipment as a LSA material as defined by current regulations or as acceptable by the disposal receiving facility, whichever is limiting.

Risk 9: The dose rate of the organic after the initial separation process will be such that, treatment, interim storage and transportation to the disposal facility can take place in unshielded vessels.

Risk number 2 is the main technical risk to the ability to produce a product that can be cleaned, handled and shipped off-site for disposal. Potential handling actions include further sampling of the $\mathrm{C}-103$ organic, aqueous, performing radionuclide analysis and contacting laboratory studies. Also a contingent treatment system such as an IX column could be designed and built.

Risk numbers 4 and 5 are the main regulatory risk to completing this task. Having to install active ventilation will increase the cost but is not expected to change the overall schedule. The inability to dispose of the aqueous return streams into C-103 or the wash water to a DST will add treatment equipment and increase overall complexity of the system.

\subsection{COST ESTIMATE}

\subsection{DESCRIPTION}

The purpose of the cost estimate is to show Rough Order of Magnitude (ROM) Study costs for removal of the separable organic phase liquid from C-103. A ROM takeoff of material quantities is utilized in the preparation of this cost estimate. Historical Hanford data and construction experience is utilized in developing the method of performance and productivity units. Construction labor, materials, and equipment units are estimated based upon both industry standard commercial estimating manuals and Hanford experience.

\subsection{ASSUMPTIONS}

The cost estimate is based on seven general assumptions as follows:

- Work is to be performed by on-site Construction Forces.

- Mockups for equipment installation are a factored allowance. 
- Contingency and site allocations are included in the installation costs.

- The exact location of the new equipment is not firm.

- Instrumentation and Controls is a factored allowance.

- Burnout allowances are not included.

- The cost estimate does not include the purchase cost of an LR-56/H Cask System. It is assumed that one is available for use.

\subsection{COST BASIS}

Direct costs are adjusted by the estimator, as appropriate, to reflect influences by work site or other identified project and special conditions. This includes (but not limited to) allowances for Special Work Procedures, sales tax, construction consumables, construction equipment usage, general conditions, etc.

Construction and procurement costs include allowances for a skimmer pump, a prefabricated pump pit, CCTV equipment, phase separation equipment and enclosure, wash tanks, and instrumentation and controls. Of these the phase separation equipment and assembly, the pump and pump pit, and instrumentation and controls are the largest cost items. Vendors were contacted for rough quotes on pump parts, lead sheets, ISO and wash tanks, coalescer, and process enclosure. Material costs for piping and fittings are priced from commercially available cost estimating manuals.

The operating contractor's biggest expense lies with the transportation and disposal costs and the operational readiness review costs. The remaining costs in the estimate for the Operating Contractor are based upon factors developed from W-314, Phases I \& II and the AZ-101 mixer pump estimate. There are $\mathrm{O} / \mathrm{C}$ for engineering support, construction support, testing and turnover, operability testing, and operation preparation.

Further information for the above items can be found in the Estimate Details in Appendix B. These include percentages used in labor and material markups, contingency analysis, escalation basis, remarks, etc.

\subsection{PROJECT COST}

The overall cost of the bulk removal of organic from $\mathrm{C}-103$ is estimated $\$ 8.8$ million. This includes; \$0.4 million for Engineering, \$1.0 million for Procurement, \$2.2 million for Construction, \$3.5 million for Operating Contractor Expenses, and \$1.7 million for Disposal and Transportation. Figure 13.1 is a Summary Cost Rollup. The cost details are shown in Appendix B. The polishing step which uses the Light Duty Utility Arm (LDUA) and an absorbent is estimated to cost $\$ 1.0$ million. 
Figure 13.1. Summary Cost Rollup (page 1 of 2)

Estimate Tree

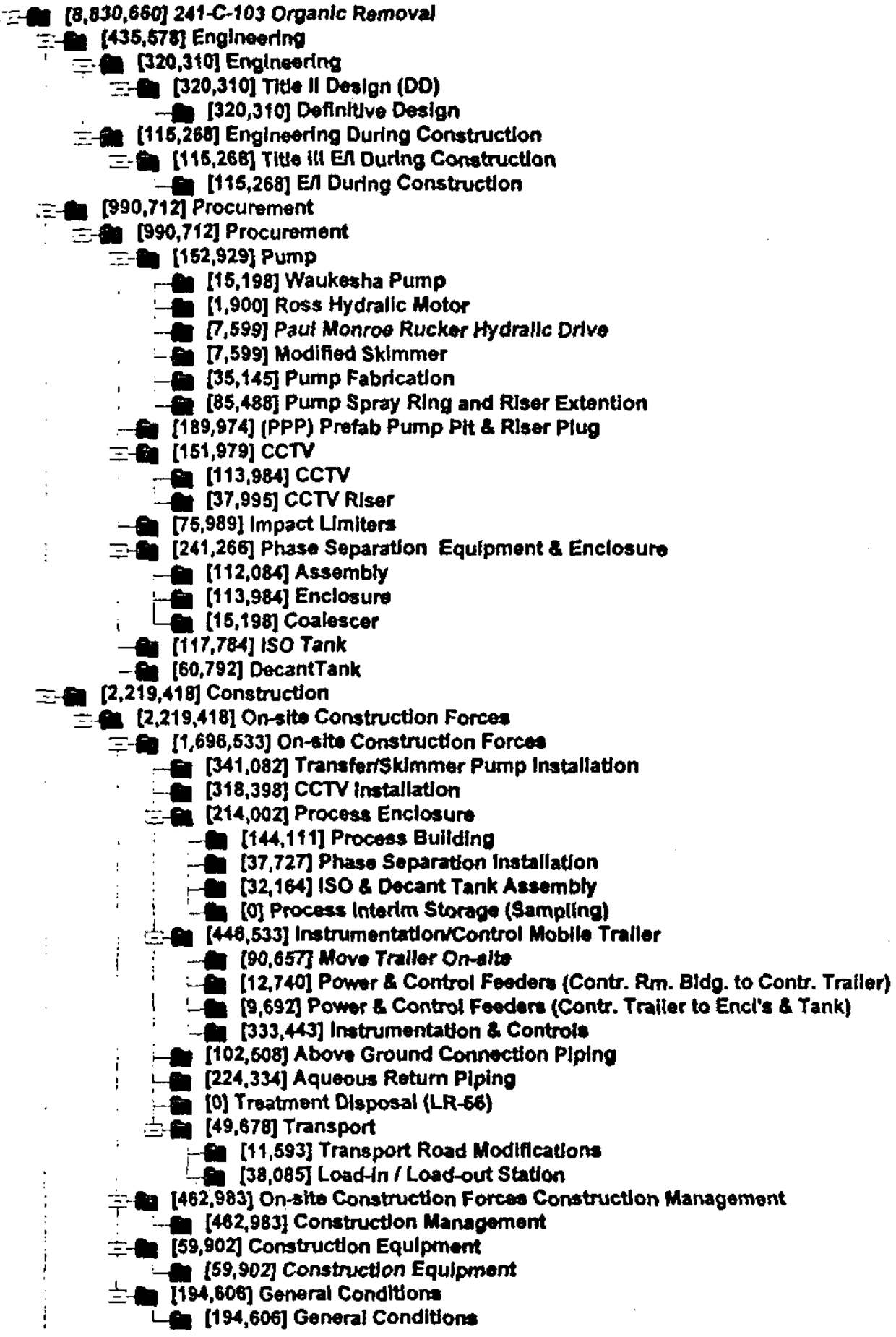


Figure 13.1. Summary Cost Rollup (page 2 of 2)

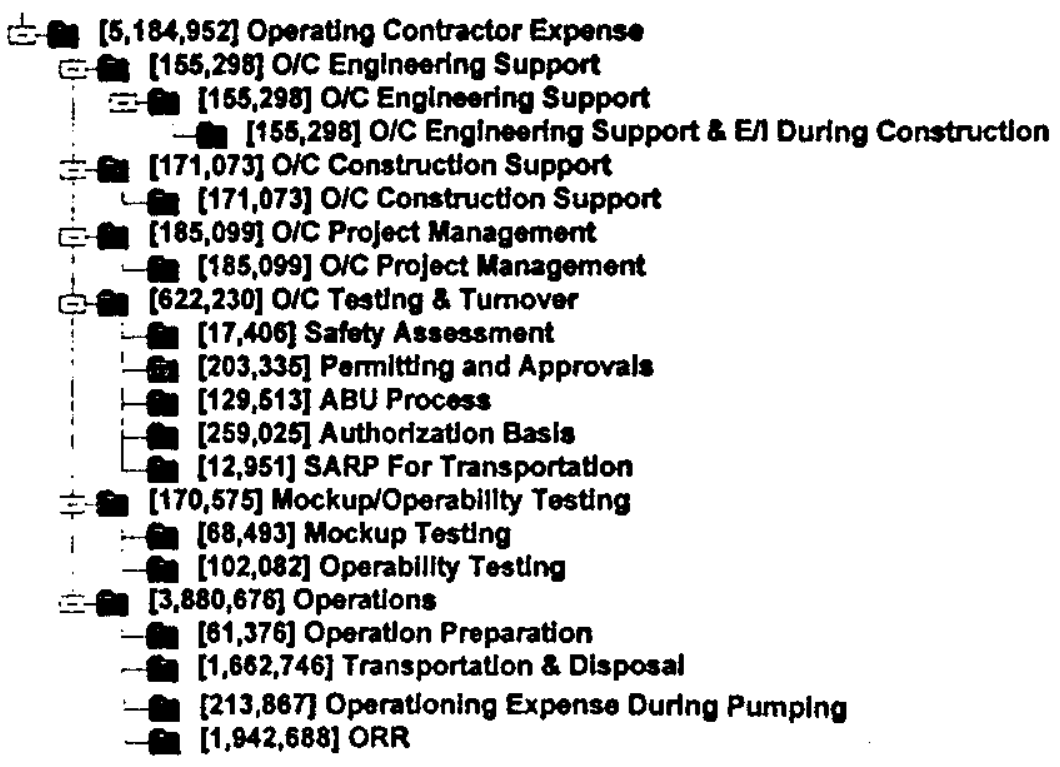




\subsection{COST REDUCTION INITIATIVES}

The costs reported in Section 13 and Appendix B are based on past experience and normal estimating techniques. The risks associated in the baseline are shown in Section 12, Risk Management. It is possible to take a higher risk profile and reduce the initial cost projections. The veracity of these options should be verified by performing small engineering evaluations before accepting them as the baseline.

The following initiatives could reduce the projected cost by several million dollars:

- $\quad$ Returning the wash solution to SST C-103 eliminates the costs and operational complexities associated with the LR-56 transfer to a DST via 204-AR and could save $\$ 200-300 \mathrm{~K}$. The increased risks are that this concept puts "newly generated" waste into a SST and the water addition can potentially impact skimmer operation.

- Changing the startup strategy from an ORR to a readiness assessment (RA) could save about $\$ 1 \mathrm{M}$. This strategy is acceptable if the Authorization Bases do not require a DOE approved change.

- Eliminating the need to remove the residual organic in C-103 (polishing step) could save $\$ 1 . M$. This is a relatively low risk change, while C-103 would look like other SST following stabilization it could affects its (C-103) removal from the watchlist.

- Changing the disposal option from incineration to solidification and burial in Nevada could potentially save $\$ 1.0 \mathrm{M}$. There are still unanswered waste acceptance criteria questions with this method.

- Close coupling of the vendor truck and the organic treatment could eliminate the need for an interim storage tank and could save $\$ 150 \mathrm{~K}$ to $\$ 200 \mathrm{~K}$.

The cost estimate for the bulk separation of the organic has $\$ 1.9 \mathrm{M}$ of contingency built into it. Following detailed design and initial procurement, the contingency should be reevaluated. 


\subsection{REFERENCES}

49 CFR 173.433, "Shippers-general requirements for shipments and packagings," Code of Federal Regulations, Washington D.C.

Bruelback, J.P., 1994, Scoping Experiments to Evaluate Combustion of Thin Organic Layers, internal letter to M. G. Plys, Fauske and Associates, Inc., January 28, Westinghouse Hanford Company, Richland, Washington

Carothers, K.G., 1988, Tank 103C Transaction History - Post 1976, letter to D. A. Dodd, 1333188-600, September 22, Westinghouse Hanford Company, Richland, Washington.

CHG, 1999, River Protection Project Administration, Volume IV, Section 5.4, "Unreviewed Safety Questions, Rev. 11d, CH2M HILL Hanford Group, Inc., Richland, Washington.

DOE-RL, 1998, Contract DE-AC06-96RL13308, Tank Waste Remediation System Privatization Contract, U.S. Department of Energy, Richland Operations Office, Richland, Washington.

Dukelow, G. T, D. A. Turn and M. J. Grigsby, 1995, Recommended Alternative for Interim Stabilization of Tank 241-C-103, WHC-EP-0862, Westinghouse Hanford Company, Richland, Washington.

Dukelow, G. T, M. J. Klem, P.L. Bartley and J.A. Reddick, 1996, Tank 241-C-103 Systems Engineering Study: Separable Phase Organic Skimming, Storage, Treatment and Disposal Options, WHC-SD-WM-ES-384, Rev. 0, Westinghouse Hanford Company, Richland, Washington.

FAI 1994, Safety Limit of Residual Organic Material in Hanford Waste Tank C-103, Progress, FAl-94-41, Fauske and Associates, Richland, Washington.

Hansen, C. E., 1999, Restart Plan for the 241-C-103 Organic Removal, WHC-SD-WM-PLN092, Rev. 0a, Lockheed Martin Hanford Corporation for Fluor Daniel Hanford, Inc., Richland, Washington.

Kinzer, J. to R. D. Hanson (FDH), "Disposition of Separable Organic Layers-Direction to Remove Separable Organic Layer From Singe-Shell Tank (SST) 241-C-103," Letter \#9954388, June 18, 1999, Department of Energy, Richland, Washington.

Lewis, J. G., 1999, Single Shell Tank Interim Stabilization Project Plan, HNF-2358, Rev. 3a, Lockheed Martin Hanford Corporation for Fluor Daniel Hanford, Inc., Richland, Washington.

LMHC, 1999a, Tank Waste Remediation System Final Safety Analysis Report, HNF-SD-WMSAR-067, Rev. 0, prepared by Lockheed Martin Hanford Corporation for Fluor Daniel Hanford, Inc., Richland, Washington. 
Lumetta, G. J. to G.T. Dukelow (WHC), "Decontamination of the Tank 241-C-103 Organic Layer by Washing with Aqueous Media," Letter \#ED-6300-RPT2, March 22, 1999, Pacific Northwest Laboratory, Richland, Washington.

McClure, L.W. to E. Pacquet (NHC), “Contract 503, Release 90, Separable Organics Treatment Options Evaluation Study Draft," Letter \#COGEMA-99-1313, September 30, 1999, COGEMA Engineering Corporation, Richland, Washington.

Pool, K. H. and R. M. Bean, 1994, Analysis of Liquid Samples from Hanford Waste Tank 241-C-103, PNL-9403, Pacific Northwest Laboratory, Richland, Washington. 
RPP-6310, Rev. 0

APPENDIX A

WASTE ACCEPTANCE CRITERIA 


\section{APPENDIX A}

WASTE ACCEPTANCE CRITERIA

Table A-1. Radioactive Content of Tank 241-C-103 - Treated (Lumetta, 1996)

\begin{tabular}{|c|c|c|c|c|c|}
\hline Radionuclides & $\begin{array}{c}\text { Analyses } \\
(1996) \\
\mu \mathrm{Ci} / \mathrm{ml}\end{array}$ & $\begin{array}{c}\text { Total } \\
\text { Radiation } \\
\mu \mathrm{C} \mathbf{i}\end{array}$ & $\begin{array}{l}\text { DSSI WAC } \\
(\mu \mathrm{Ci})^{\star *}\end{array}$ & $\begin{array}{c}\text { Weight } \\
\text { Total gm* }\end{array}$ & $\begin{array}{c}\text { DSSI WAC } \\
(\mathrm{gm})^{* *}\end{array}$ \\
\hline $90 \mathrm{Sr}$ & $3.51 \mathrm{E}-01$ & $6.39 \mathrm{E}+06$ & \multirow[t]{2}{*}{$1.00 \mathrm{E}+07$} & & \\
\hline $154 \mathrm{Eu}$ & $2.11 \mathrm{E}-04$ & $3.84 \mathrm{E}+03$ & & & \\
\hline $3 \mathrm{H}$ & $5.80 \mathrm{E}-04$ & $1.06 \mathrm{E}+04$ & $5.00 \mathrm{E}+09$ & & \\
\hline $60 \mathrm{Co}$ & $4.44 \mathrm{E}-04$ & $8.08 \mathrm{E}+03$ & \multirow[b]{2}{*}{$1.00 \mathrm{E}+07$} & & \\
\hline $137 \mathrm{Cs}$ & $1.09 \mathrm{E}-02$ & $1.98 \mathrm{E}+05$ & & & \\
\hline $14 \mathrm{C}$ & $2.60 \mathrm{E}-04$ & $4.73 \mathrm{E}+03$ & $1.00 \mathrm{E}+08$ & & \\
\hline $241 \mathrm{Am}$ & $4.96 \mathrm{E}-04$ & $9.03 \mathrm{E}+03$ & $1.00 \mathrm{E}+05$ & & \\
\hline $239 \mathrm{Pu}$ & $6.50 \mathrm{E}-05$ & $1.18 \mathrm{E}+03$ & & $1.93 \mathrm{E}-02$ & \multirow[b]{2}{*}{$2.00 \mathrm{E}+02$} \\
\hline $\begin{array}{c}* 238 \mathrm{Pu}+241 \mathrm{~A} \\
\mathrm{~m}\end{array}$ & $1.70 \mathrm{E}-04$ & $3.09 \mathrm{E}+03$ & & $1.78 \mathrm{E}-04$ & \\
\hline $\begin{array}{c}* * 238 \mathrm{Pu}+241 \\
\mathrm{Am}\end{array}$ & $1.70 \mathrm{E}-04$ & $3.09 \mathrm{E}+03$ & $1.00 \mathrm{E}+05$ & & \\
\hline
\end{tabular}

Specific Gravity of Organics $=$

$1.64 \mathrm{E}+04$

$\begin{array}{ll}\text { Total Volume separable organic }= & 1.82 \mathrm{E}+07 \mathrm{ml}(=18,200 \mathrm{~L}) \\ \text { Specific Activity } 239 \mathrm{Pu}= & 6.13 \mathrm{E}-02 \mathrm{Ci} / \mathrm{gm} \\ \text { Specific Activity } 238 \mathrm{Pu}= & 1.74 \mathrm{E}+01 \mathrm{Ci} / \mathrm{gm}\end{array}$

* Assumes all the activity from $238 \mathrm{Pu}+241 \mathrm{Am}$ is from $238 \mathrm{Pu}$ to create a worst-case scenario in calculating amount of $238 \mathrm{Pu}$ since the WAC is different for each species. The total $(1.78 \mathrm{E}-04)$ is less than the WAC limit of $2 \mathrm{E}+2$.

*** Assumes all the activity from $238 \mathrm{Pu}+241 \mathrm{Am}$ is from $241 \mathrm{Am}$ to create a worst-case scenario in calculating amount of $241 \mathrm{Am}$ since the WAC is different for each species. The total, combined with the individual $241 \mathrm{Am}(1.21 \mathrm{E}+04)$ is less than the WAC limit of $1 \mathrm{E}+5$.

Table A-2. ATG Waste Acceptance Criteria-Activity Limits, Draft July 5, 1999, Rev. 0

\begin{tabular}{|c|c|c|c|}
\hline Radionuclide Species & $\boldsymbol{\mu ~ C i} / \mathbf{m l}$ & $\mathbf{C i}$ & ATG WAC \\
\hline $90 \mathrm{Sr}$ & $3.51 \mathrm{E}-01$ & $6.39 \mathrm{E}+00$ & $1 \mathrm{Ci}$ \\
\hline $14 \mathrm{C}$ & $2.11 \mathrm{E}-04$ & $3.84 \mathrm{E}-03$ & $2 \mathrm{Ci}$ \\
\hline $3 \mathrm{H}$ & $5.80 \mathrm{E}-04$ & $1.06 \mathrm{E}-02$ & $10 \mathrm{Ci}$ \\
\hline $60 \mathrm{Co}$ & $4.44 \mathrm{E}-04$ & $8.08 \mathrm{E}-03$ & \\
\cline { 1 - 3 } $137 \mathrm{Cs}$ & $1.09 \mathrm{E}-02$ & $1.98 \mathrm{E}-01$ & \\
\cline { 1 - 3 } $154 \mathrm{Eu}$ & $2.60 \mathrm{E}-04$ & $4.73 \mathrm{E}-03$ & \multirow{2}{*}{$2.0 \mathrm{Ci}$} \\
\cline { 1 - 3 } $241 \mathrm{Am}$ & $4.96 \mathrm{E}-04$ & $9.03 \mathrm{E}-03$ & \\
\cline { 1 - 3 } $239 \mathrm{Pu}$ & $6.50 \mathrm{E}-05$ & $1.18 \mathrm{E}-03$ & \\
\hline $238 \mathrm{Pu}+241 \mathrm{Am}$ & $1.70 \mathrm{E}-04$ & $3.09 \mathrm{E}-03$ & \\
\hline
\end{tabular}


Table A-3. Untreated Tank 241-C-103 Separable Organic Phase Liquid Offsite Shipping Limits for Bulk Liquid (LSA-II) (from 49 CFR 173.427)

\begin{tabular}{|c|c|c|c|}
\hline Radionuclide & $\begin{array}{c}\text { Organic Phase } \\
\text { Activity }\end{array}$ & $\begin{array}{c}\text { Organic Phase } \\
\text { Activity }\end{array}$ & \multirow{2}{*}{ *Shipping Limits } \\
\cline { 3 - 3 } & $(\boldsymbol{\mu} \mathbf{C i} / \mathbf{m l})$ & $(\mathbf{C i})$ & \multirow{2}{*}{$(\mathbf{1 0 0} \mathbf{~ A 2 ~ C i )}$} \\
\hline \hline $90 \mathrm{Sr}$ & $3.51 \mathrm{E}-01$ & $6.39 \mathrm{E}+00$ & $2.70 \mathrm{E}+02$ \\
\hline $154 \mathrm{Eu}$ & $2.11 \mathrm{E}-04$ & $3.84 \mathrm{E}-03$ & $1.35 \mathrm{E}+03$ \\
\hline $3 \mathrm{H}$ & $5.80 \mathrm{E}-04$ & $1.06 \mathrm{E}-02$ & $1.08 \mathrm{E}+05$ \\
\hline $60 \mathrm{Co}$ & $4.44 \mathrm{E}-04$ & $8.08 \mathrm{E}-03$ & $1.08 \mathrm{E}+03$ \\
\hline $137 \mathrm{Cs}$ & $1.09 \mathrm{E}-02$ & $1.98 \mathrm{E}-01$ & $1.35 \mathrm{E}+03$ \\
\hline $14 \mathrm{C}$ & $2.60 \mathrm{E}-04$ & $4.73 \mathrm{E}-03$ & $5.41 \mathrm{E}+03$ \\
\hline$* 241 \mathrm{Am}$ & $4.96 \mathrm{E}-04$ & $9.03 \mathrm{E}-03$ & $5.41 \mathrm{E}-01$ \\
\hline $239 \mathrm{Pu}$ & $6.50 \mathrm{E}-05$ & $1.18 \mathrm{E}-03$ & $5.41 \mathrm{E}-01$ \\
\hline$* 238 \mathrm{Pu}$ & $1.70 \mathrm{E}-05$ & $3.09 \mathrm{E}-03$ & $5.41 \mathrm{E}-01$ \\
\hline
\end{tabular}

Specific Gravity of Organics $=0.873$

*Packaging Requirements: IP-2 (49 CFR 173.427, Table 9)

Table 8-4. LSA-II Shipping Classification for Tank 241 C-103 - Untreated Separable Organics

\begin{tabular}{|c|c|c|c|c|}
\hline Radionuclide & $\begin{array}{c}\text { Organic Phase } \\
\text { Activity }\end{array}$ & $\begin{array}{c}\text { Organic Phase } \\
\text { Activity }\end{array}$ & $\begin{array}{c}\text { Organic Phase } \\
\text { Activity }\end{array}$ & $\begin{array}{c}\text { LSA-II Limit (Ci/gm) } \\
(\mathbf{1 . 0 E - 5} \text { A2/gm) }\end{array}$ \\
\cline { 2 - 4 } & $\boldsymbol{\mu} \mathbf{C i} / \mathbf{m l}$ & $\boldsymbol{\mu} \mathbf{C i} / \mathbf{g m}$ & $\mathbf{C i} / \mathbf{g m}$ & \\
\hline \hline $90 \mathrm{Sr}$ & $3.51 \mathrm{E}-01$ & $4.02 \mathrm{E}-01$ & $4.02 \mathrm{E}-07$ & $2.70 \mathrm{E}-05$ \\
\hline $154 \mathrm{Eu}$ & $2.11 \mathrm{E}-04$ & $2.42 \mathrm{E}-04$ & $2.42 \mathrm{E}-10$ & $1.35 \mathrm{E}-04$ \\
\hline $3 \mathrm{H}$ & $5.80 \mathrm{E}-04$ & $6.64 \mathrm{E}-04$ & $6.64 \mathrm{E}-10$ & $1.08 \mathrm{E}-02$ \\
\hline $60 \mathrm{Co}$ & $4.44 \mathrm{E}-04$ & $5.09 \mathrm{E}-04$ & $5.09 \mathrm{E}-10$ & $1.08 \mathrm{E}-04$ \\
\hline $137 \mathrm{Cs}$ & $1.09 \mathrm{E}-02$ & $1.25 \mathrm{E}-02$ & $1.25 \mathrm{E}-08$ & $1.35 \mathrm{E}-04$ \\
\hline $14 \mathrm{C}$ & $2.60 \mathrm{E}-04$ & $2.98 \mathrm{E}-04$ & $2.98 \mathrm{E}-10$ & $5.41 \mathrm{E}-04$ \\
\hline $241 \mathrm{Am}$ & $4.96 \mathrm{E}-04$ & $5.68 \mathrm{E}-04$ & $5.68 \mathrm{E}-10$ & $5.41 \mathrm{E}-08$ \\
\hline $239 \mathrm{Pu}$ & $6.50 \mathrm{E}-05$ & $7.45 \mathrm{E}-05$ & $7.45 \mathrm{E}-11$ & $5.41 \mathrm{E}-08$ \\
\hline $\begin{array}{c}238 \mathrm{Pu}+241 \mathrm{~A} \\
\mathrm{~m}\end{array}$ & $1.70 \mathrm{E}-04$ & $1.95 \mathrm{E}-04$ & $1.95 \mathrm{E}-10$ & $5.41 \mathrm{E}-08$ \\
\hline
\end{tabular}


RPP-6310, Rev. 0

\section{APPENDIX B}

Cost 
家

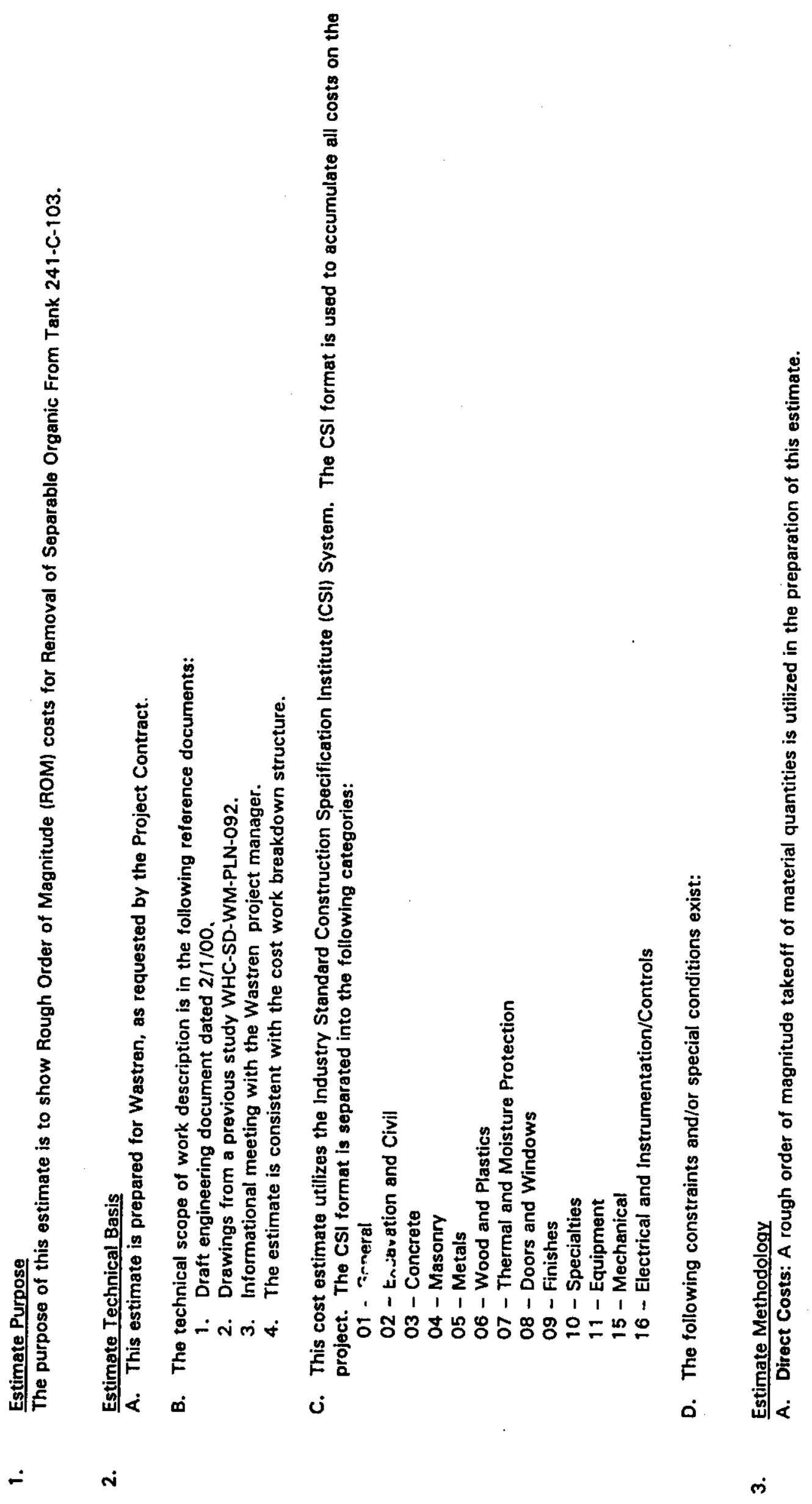


文
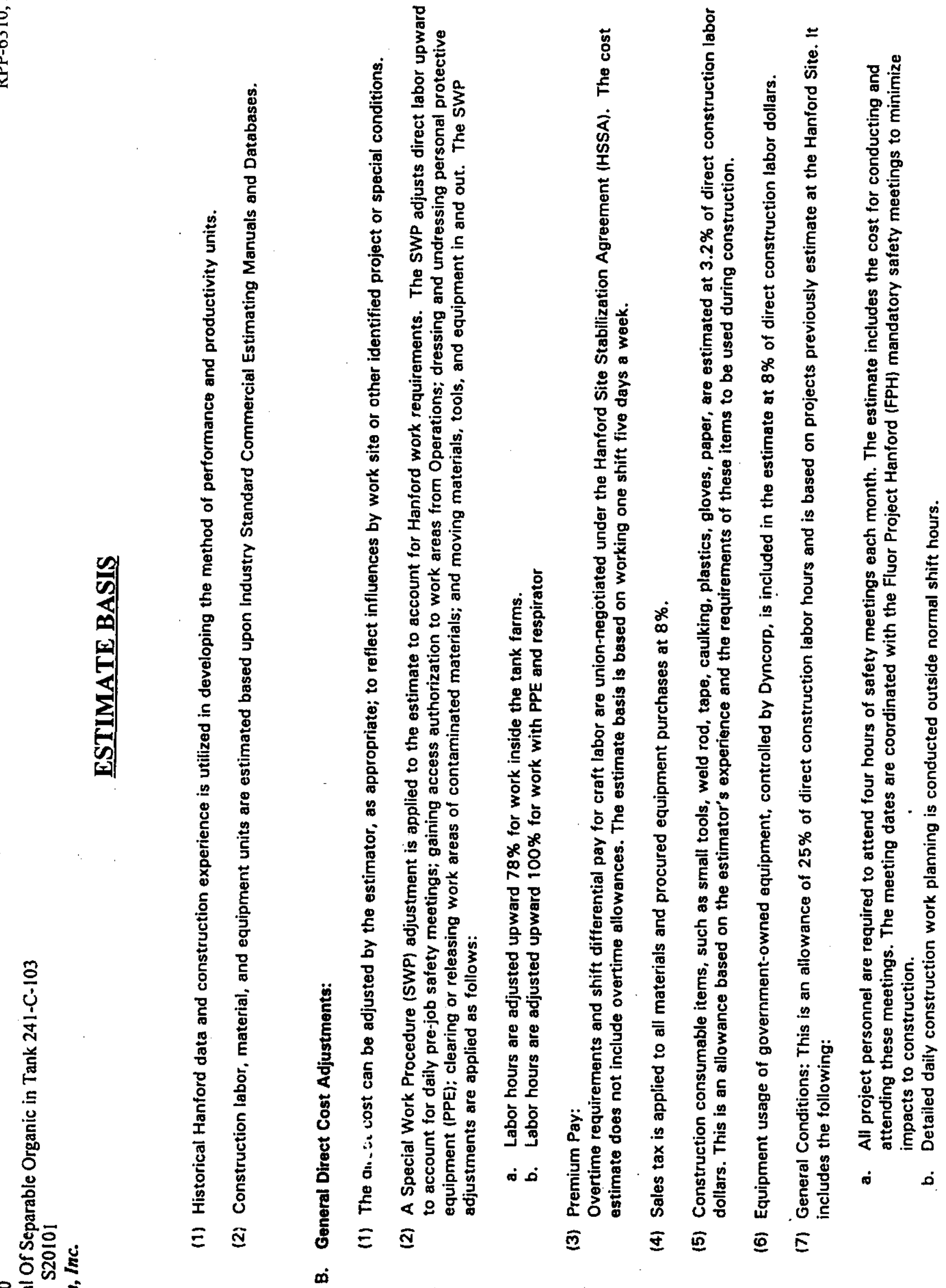

용 
㐫

句

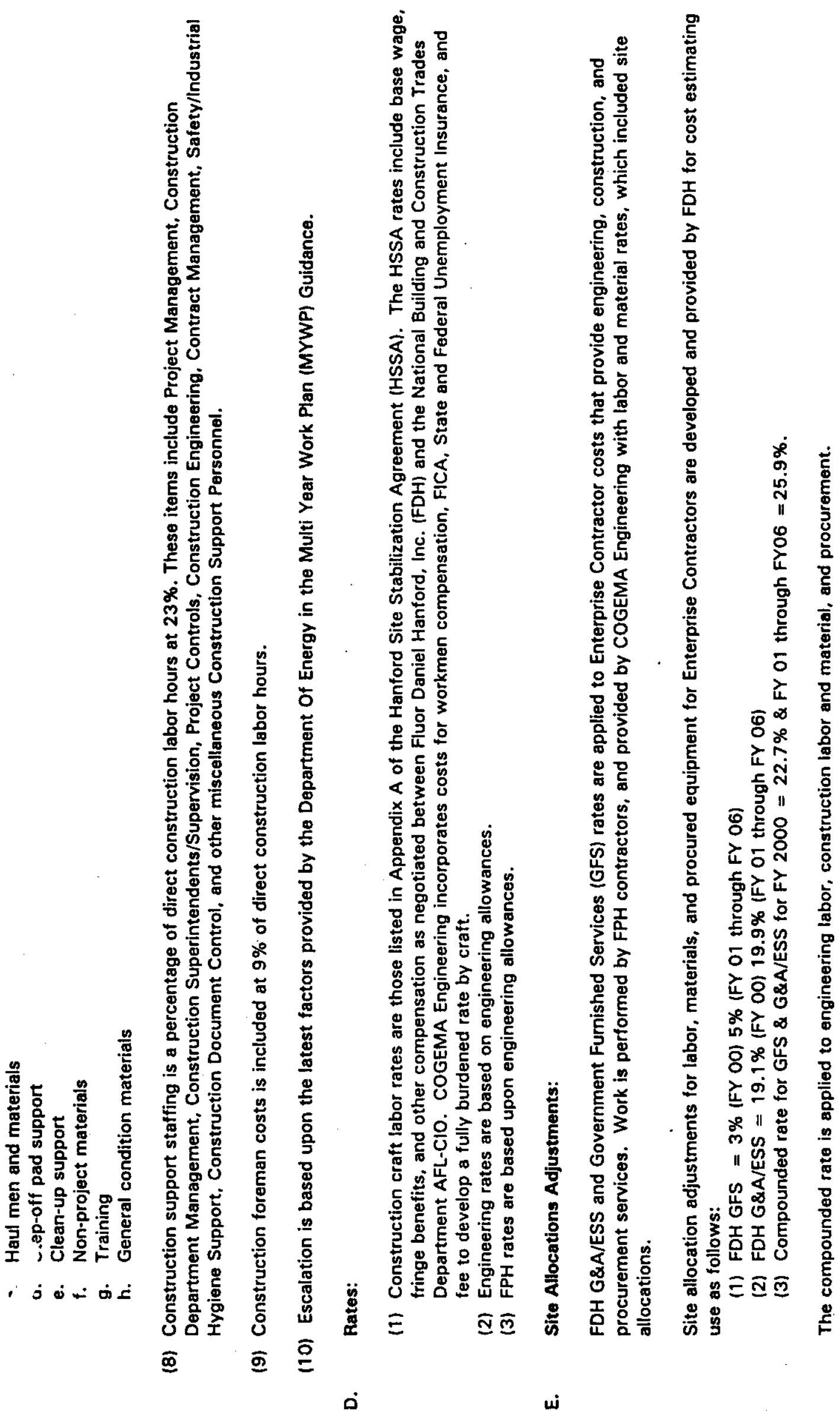


0
$\dot{a}$
0
0
0
01
0
0
0
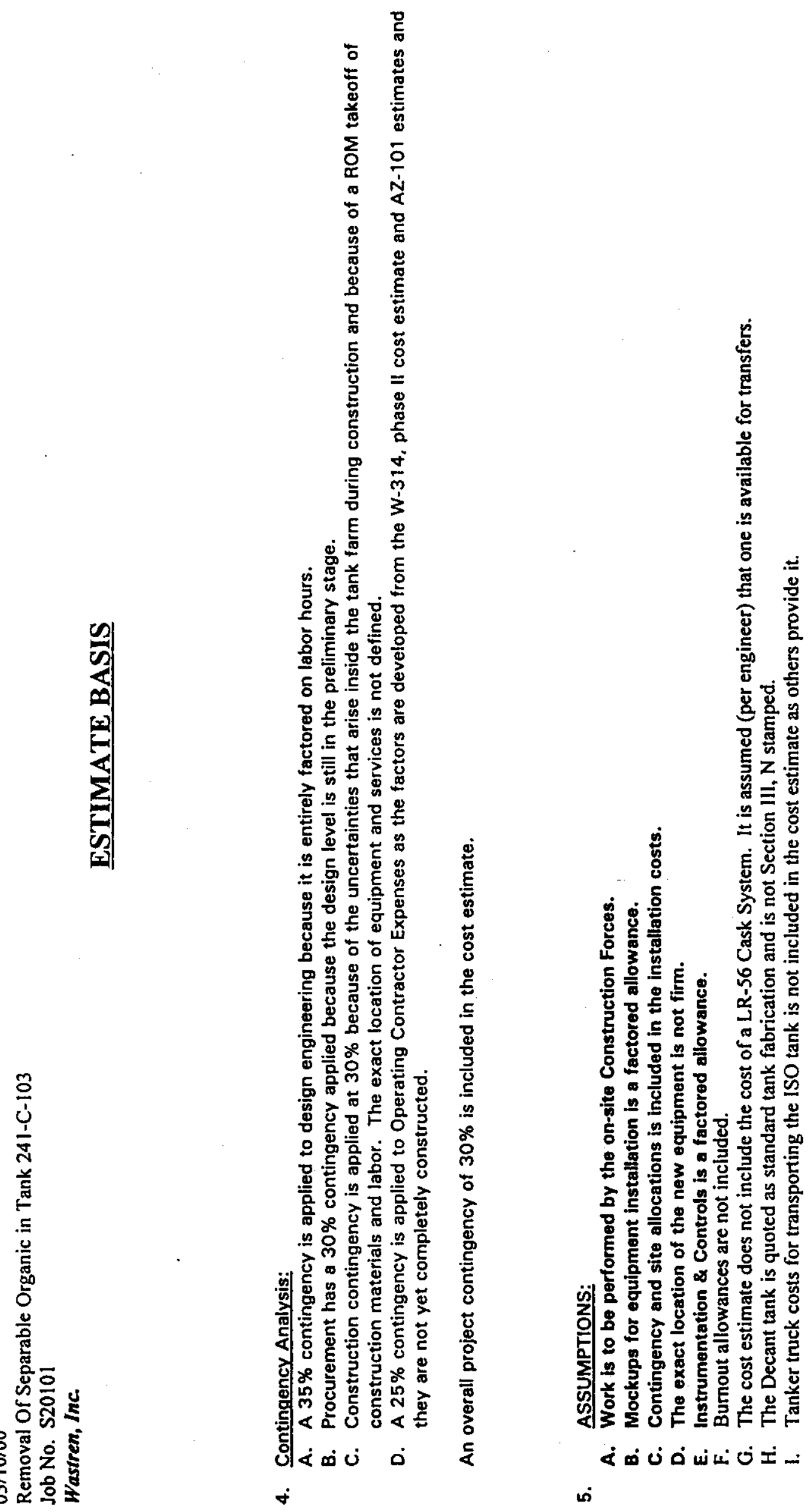


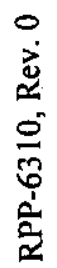
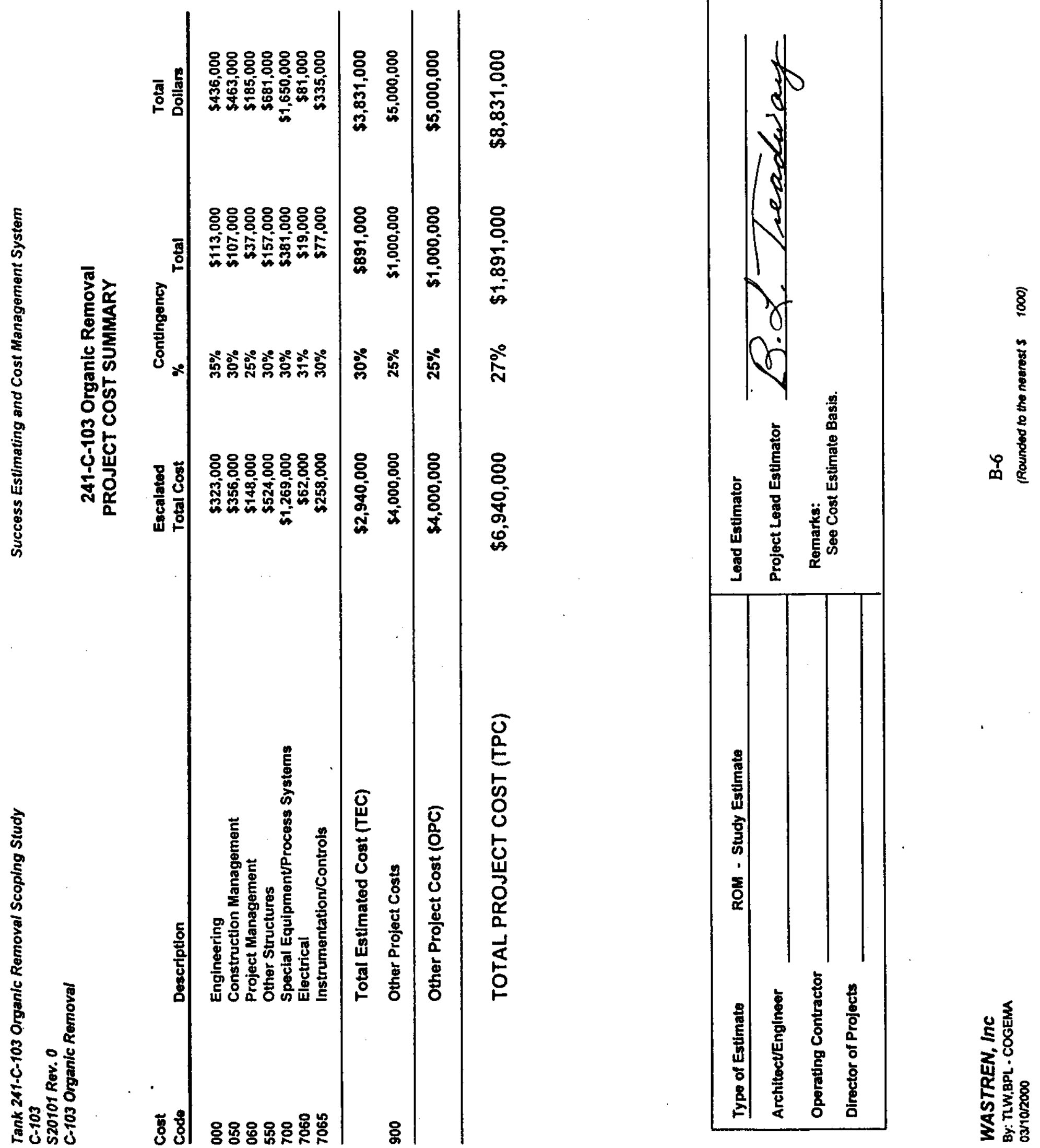


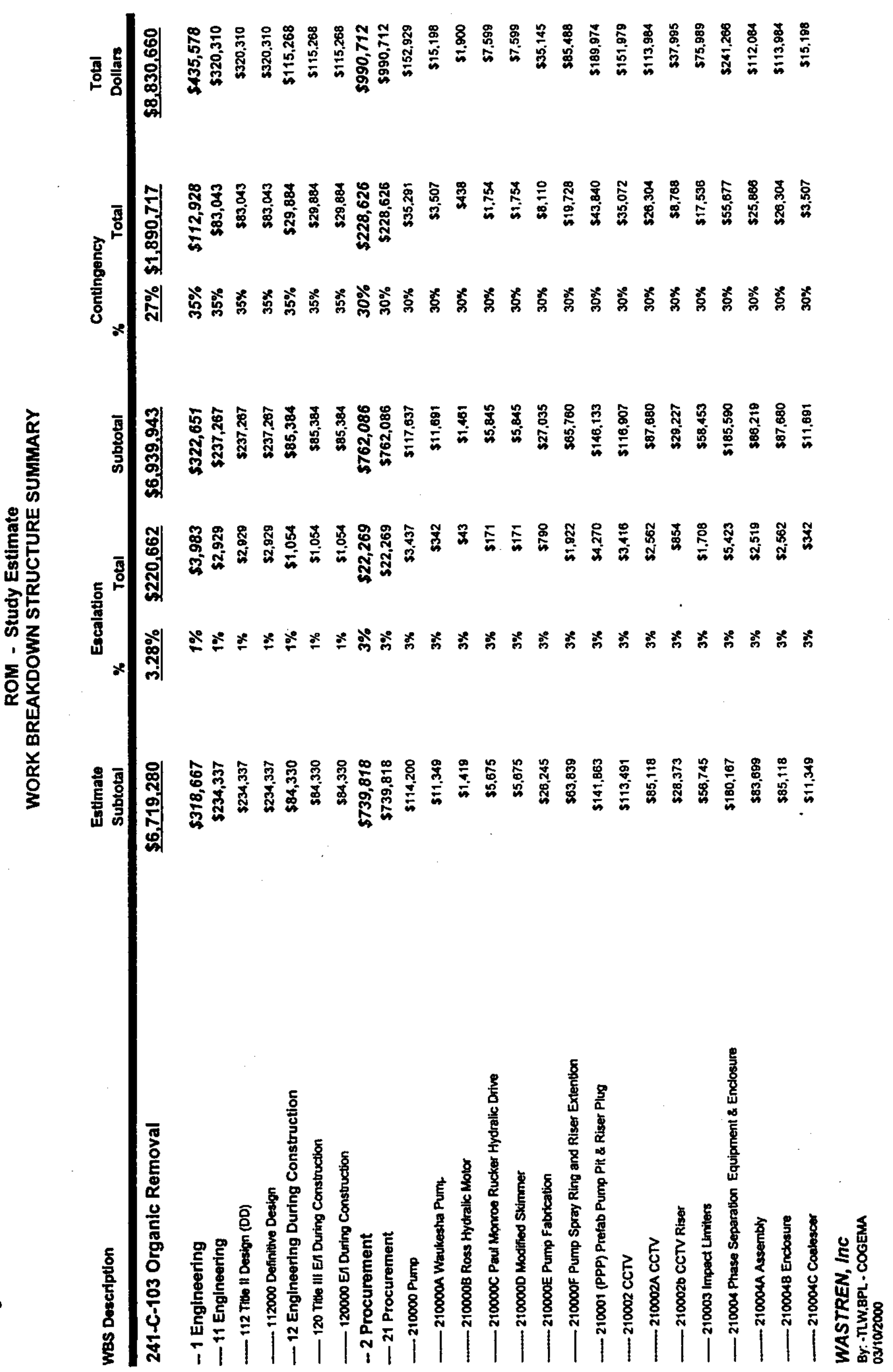




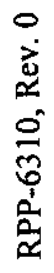

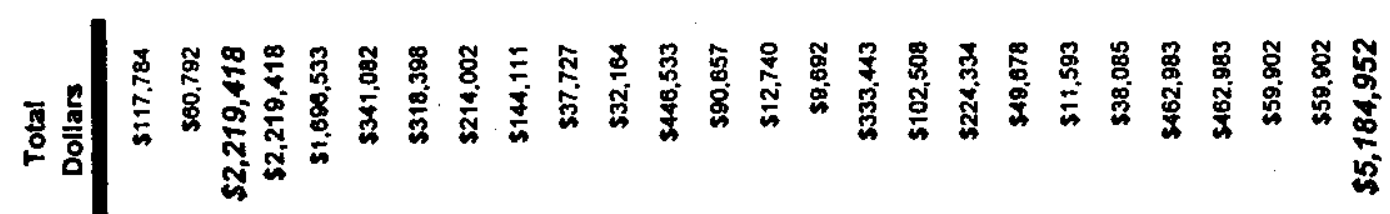

몽
2
2

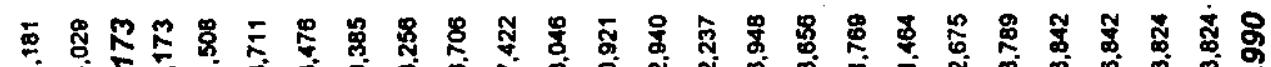

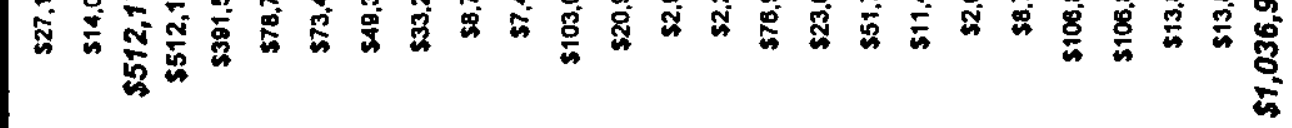
高

जิ

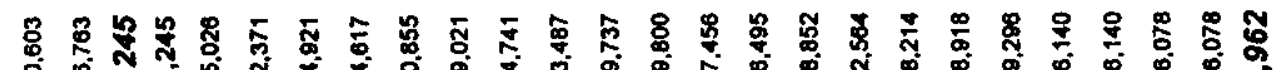

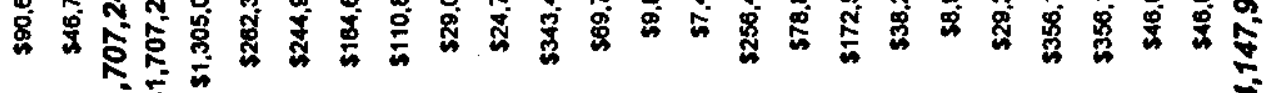
is

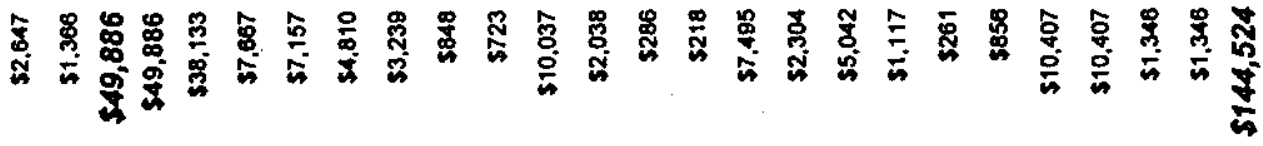
ผ

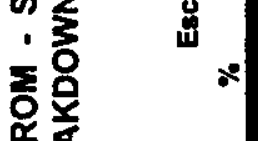

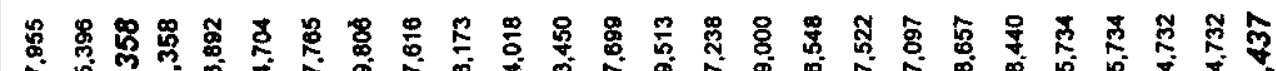

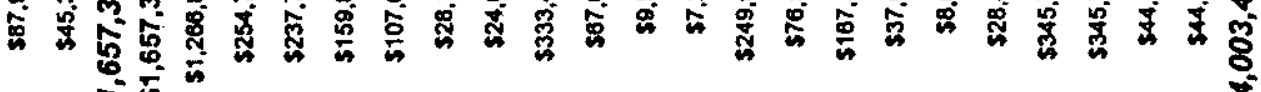

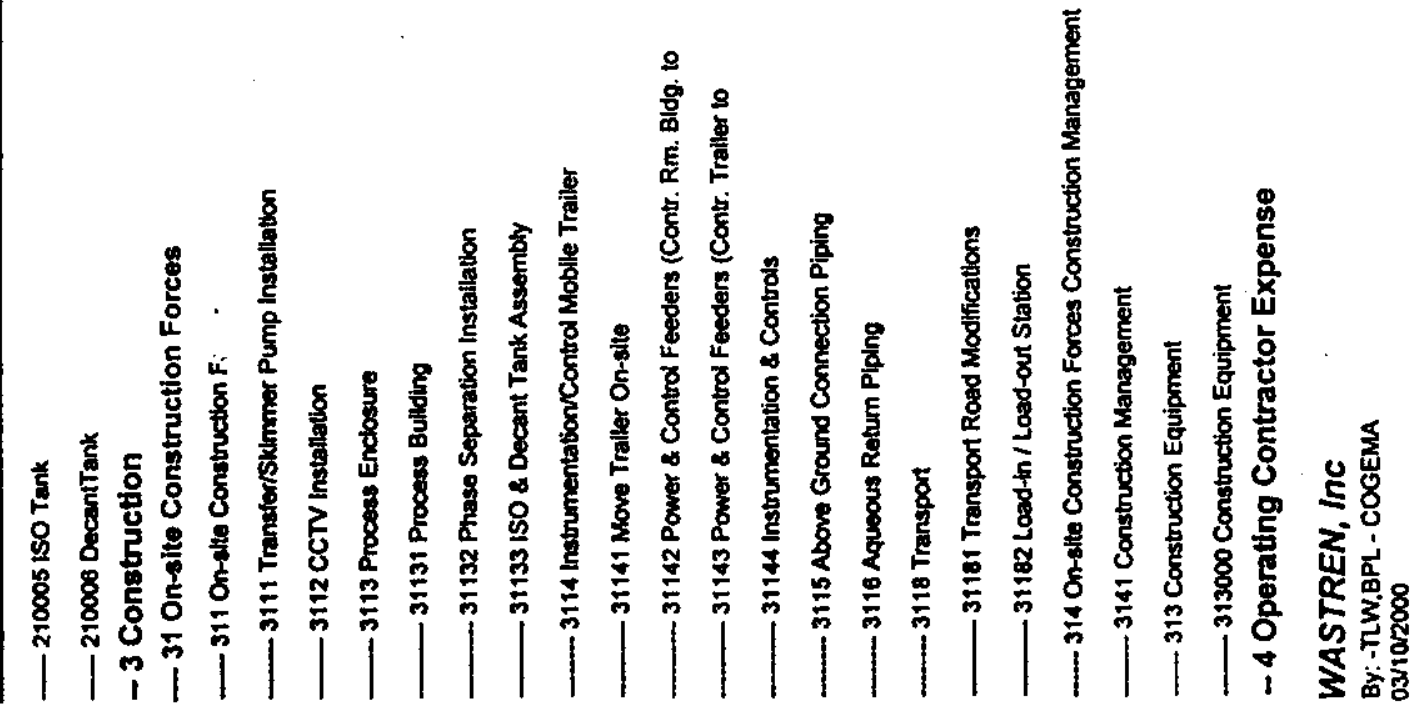




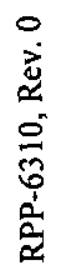

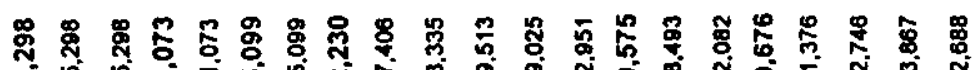

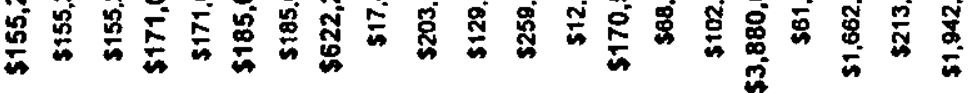

푱

遇速先

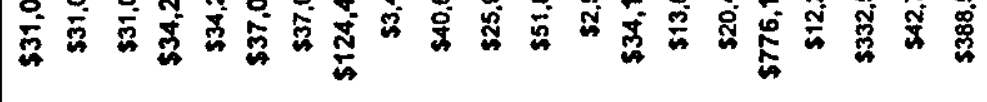

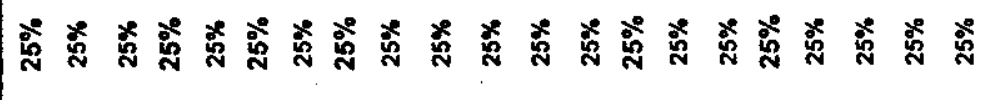

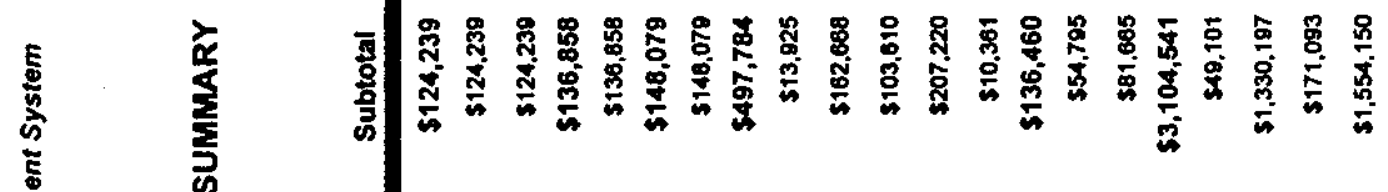

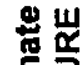

票它

홀

3

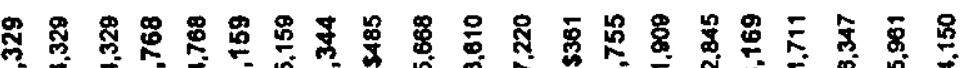

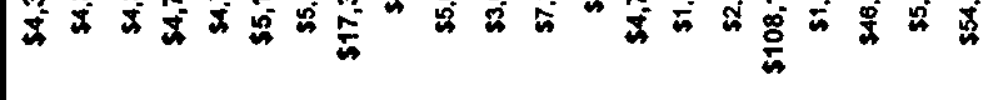

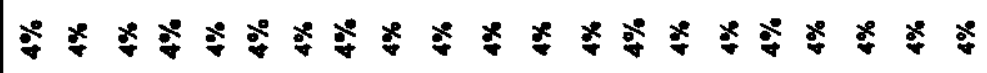

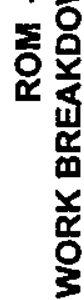

鄫总

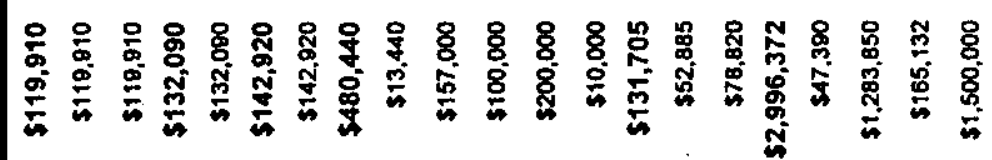

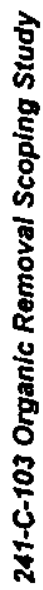

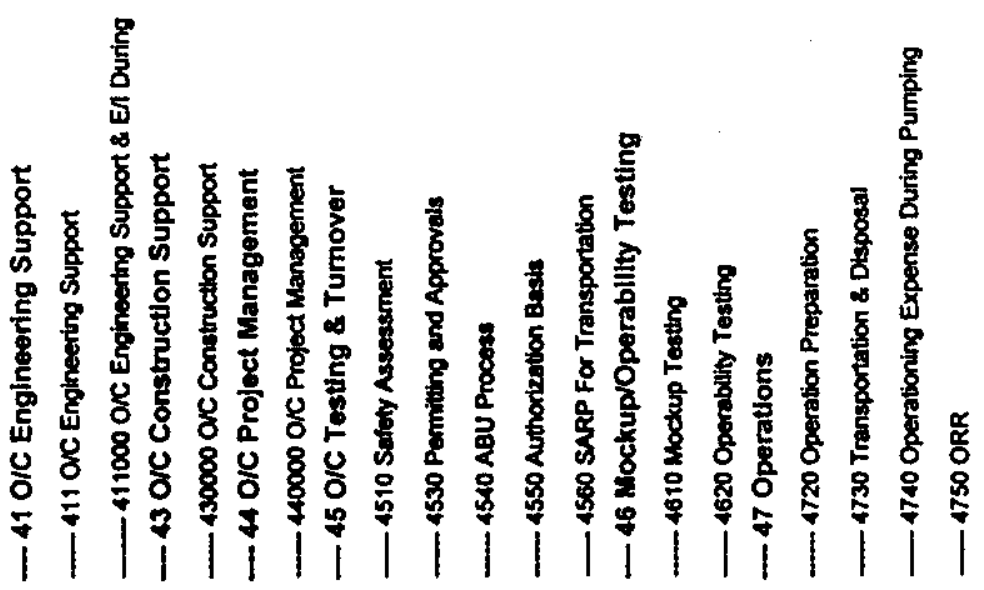




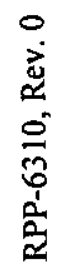

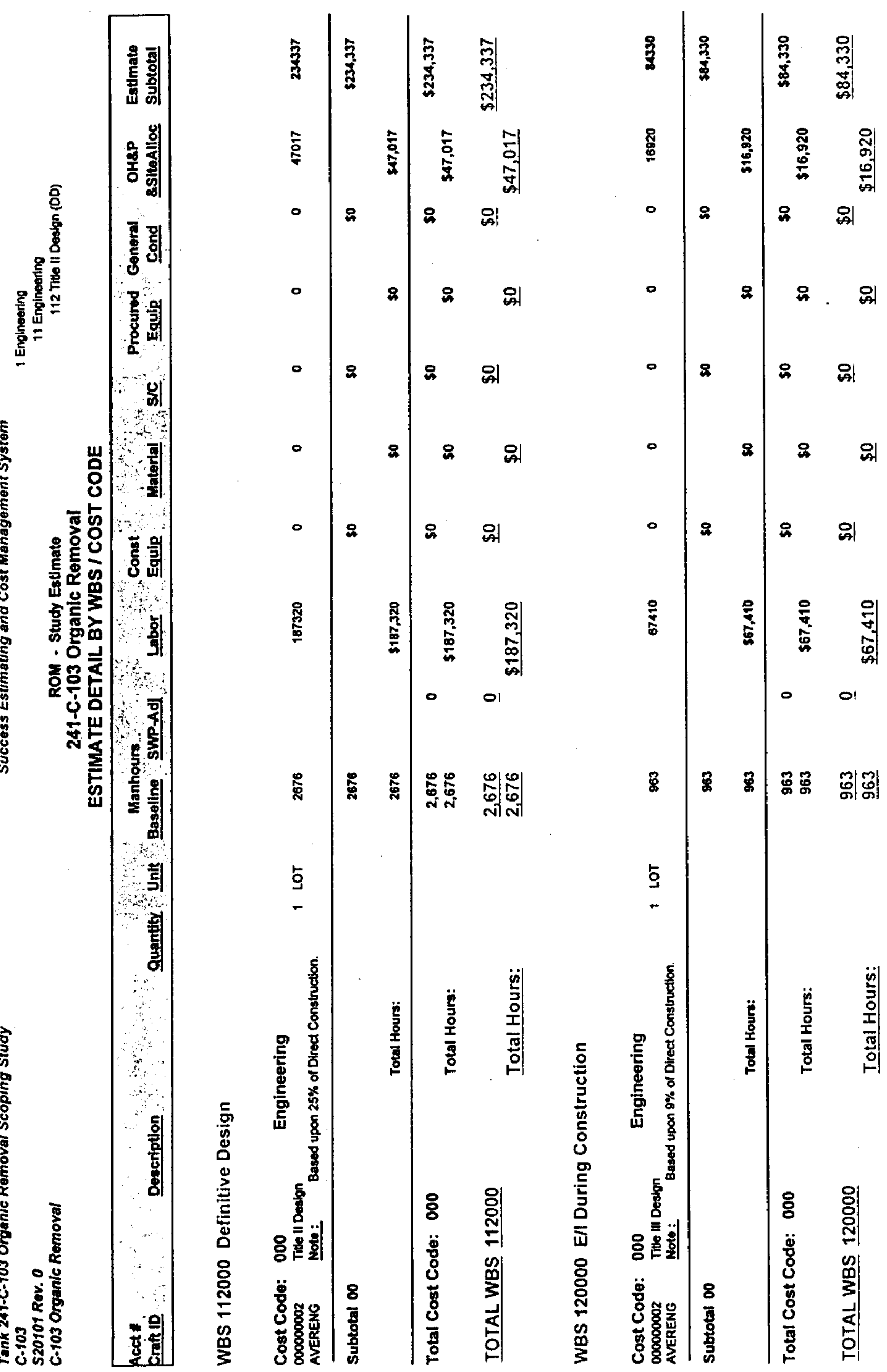




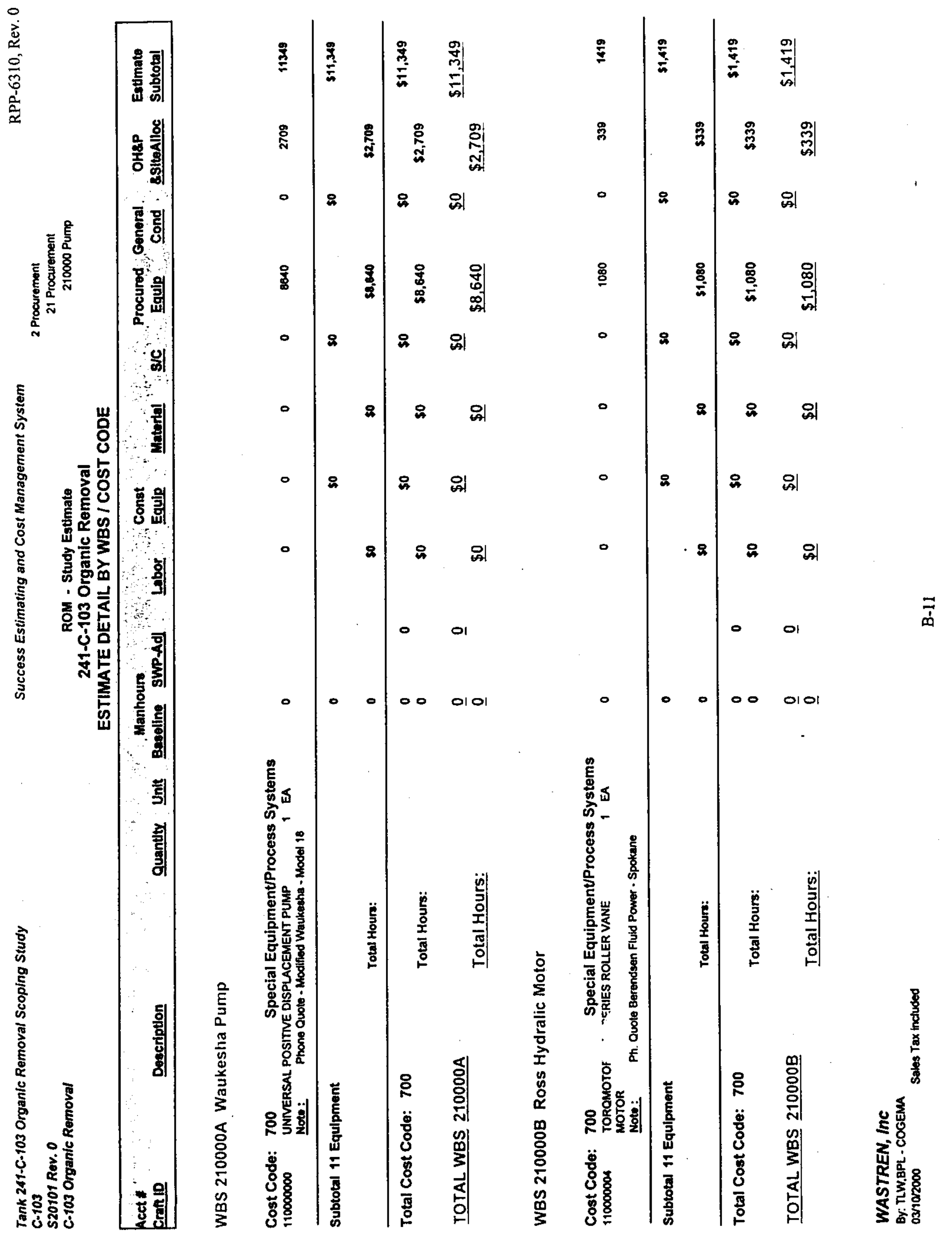




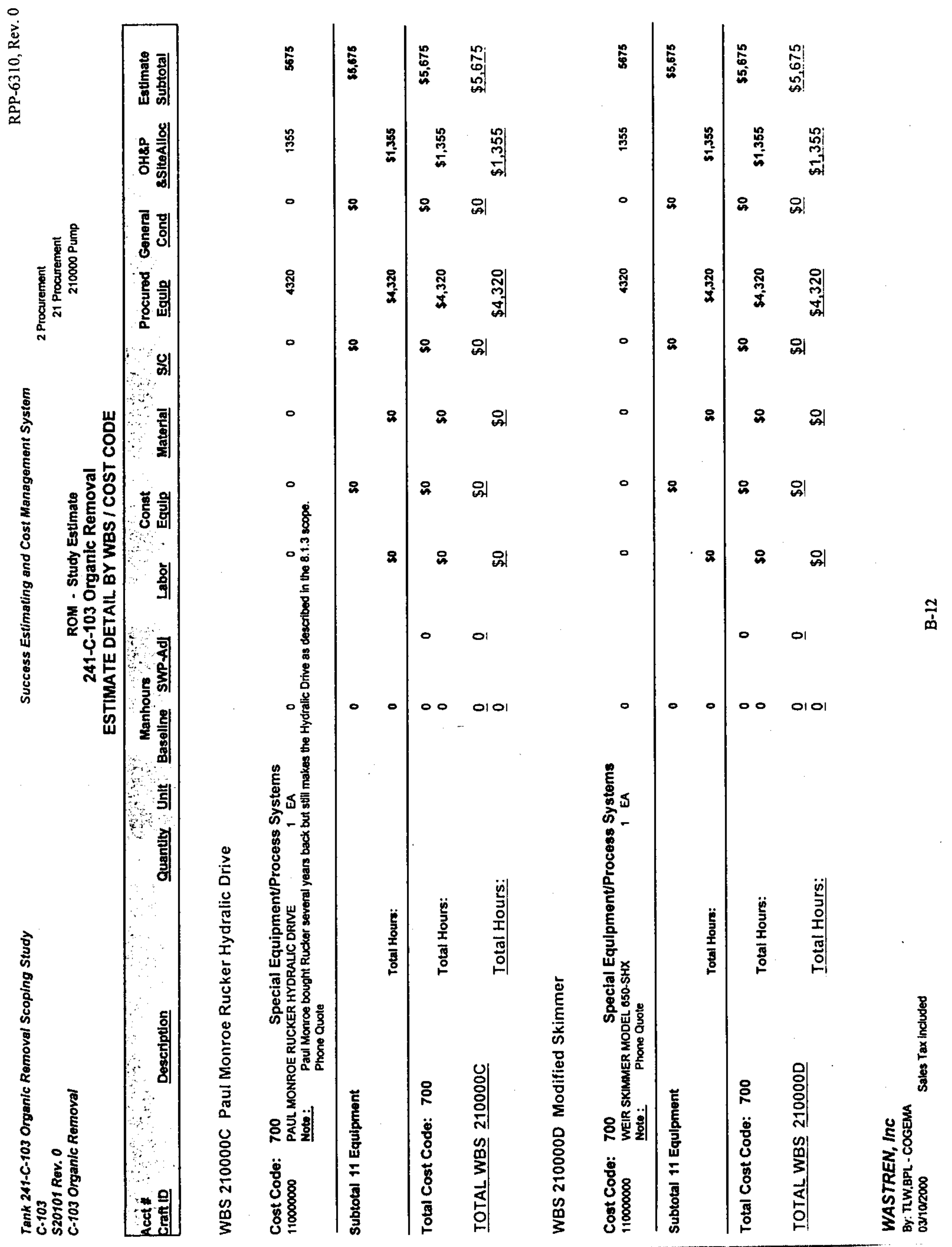




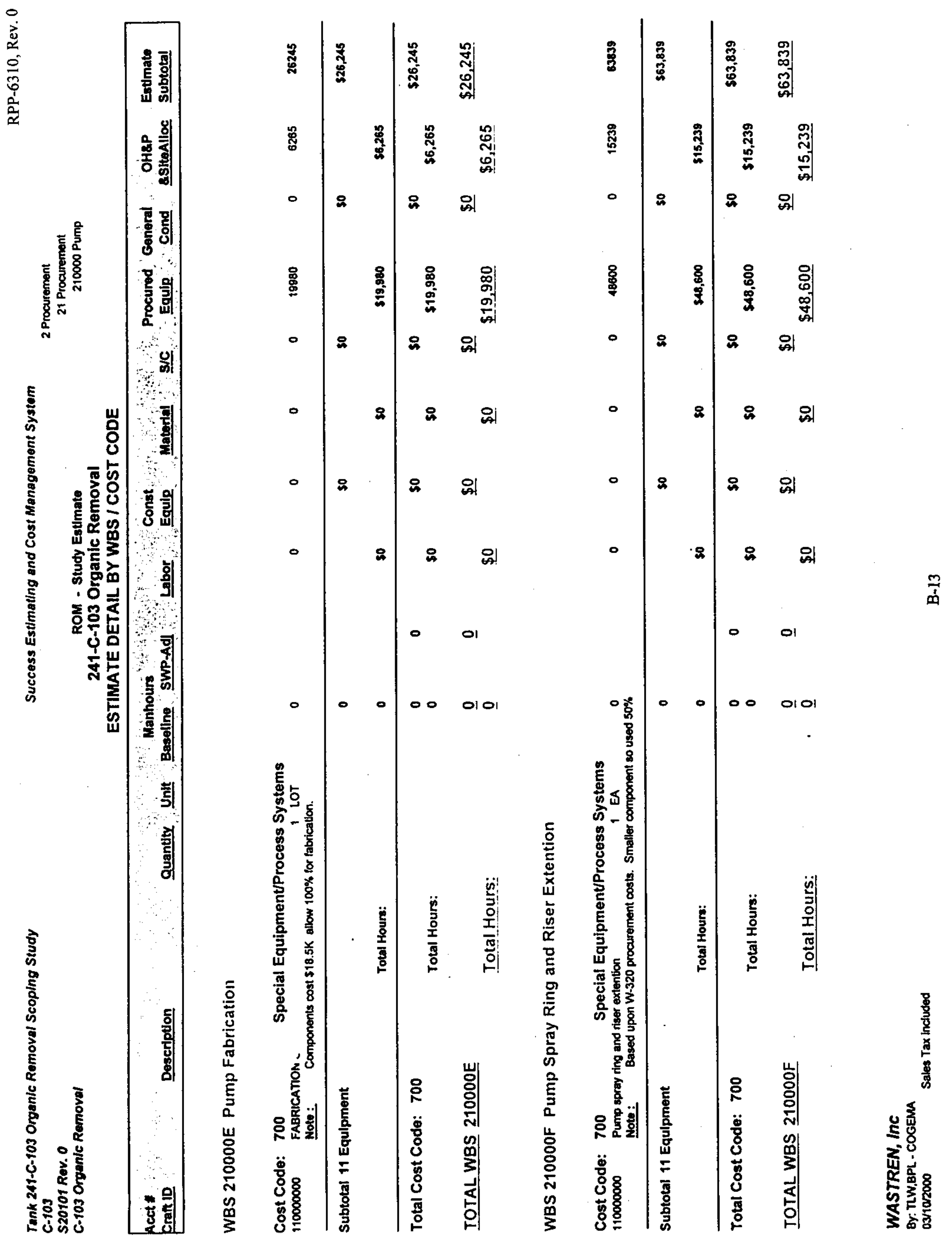




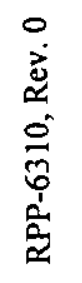

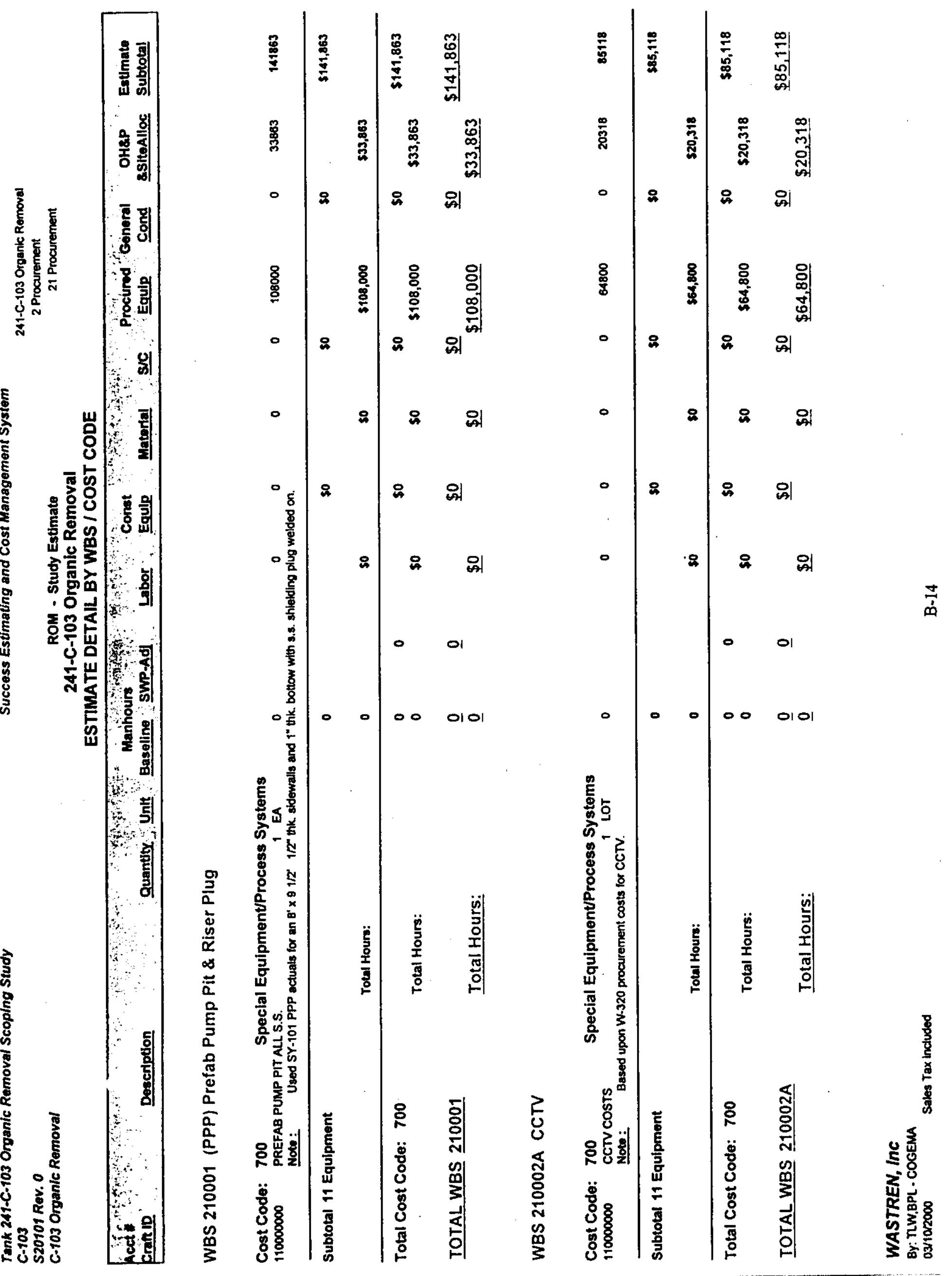




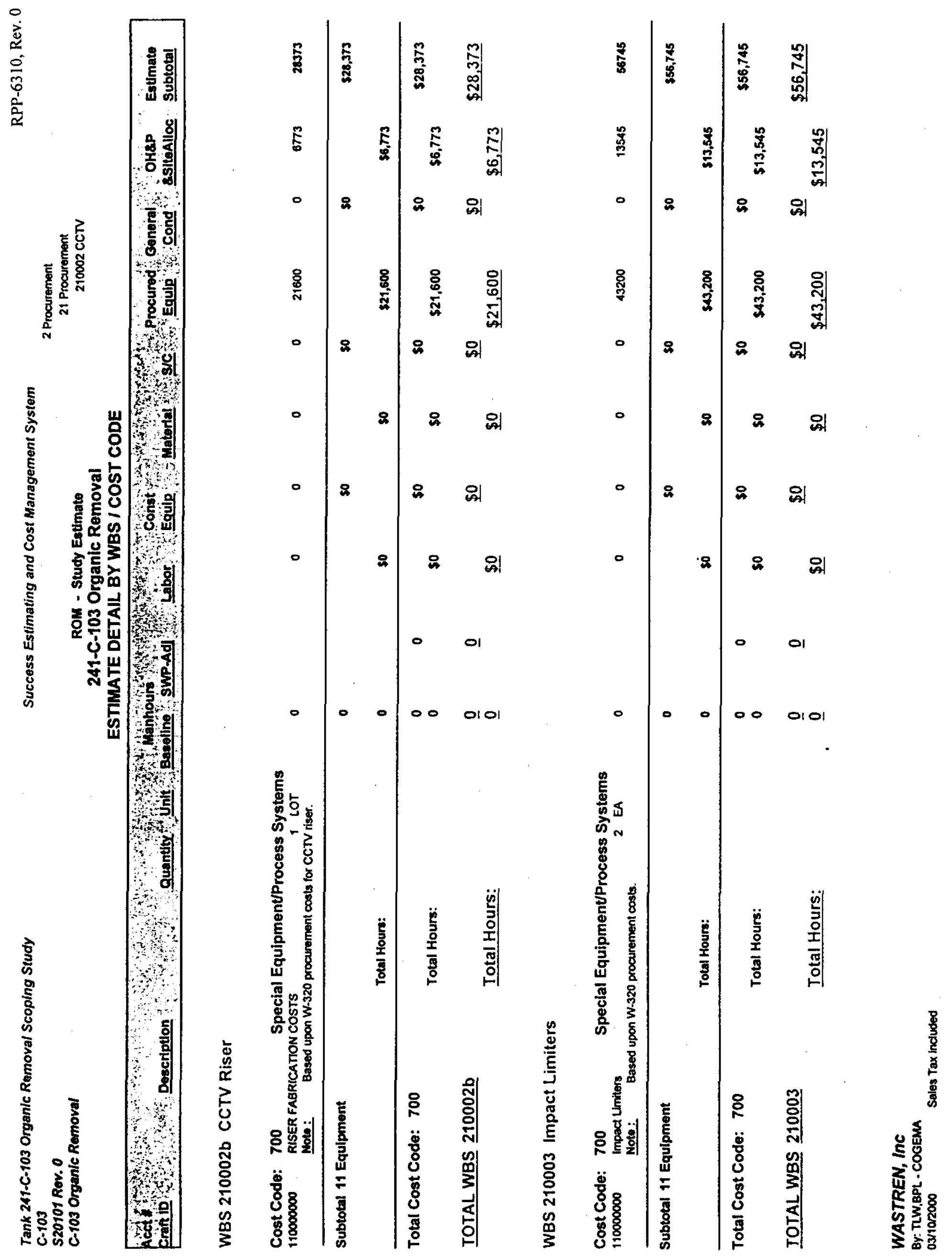




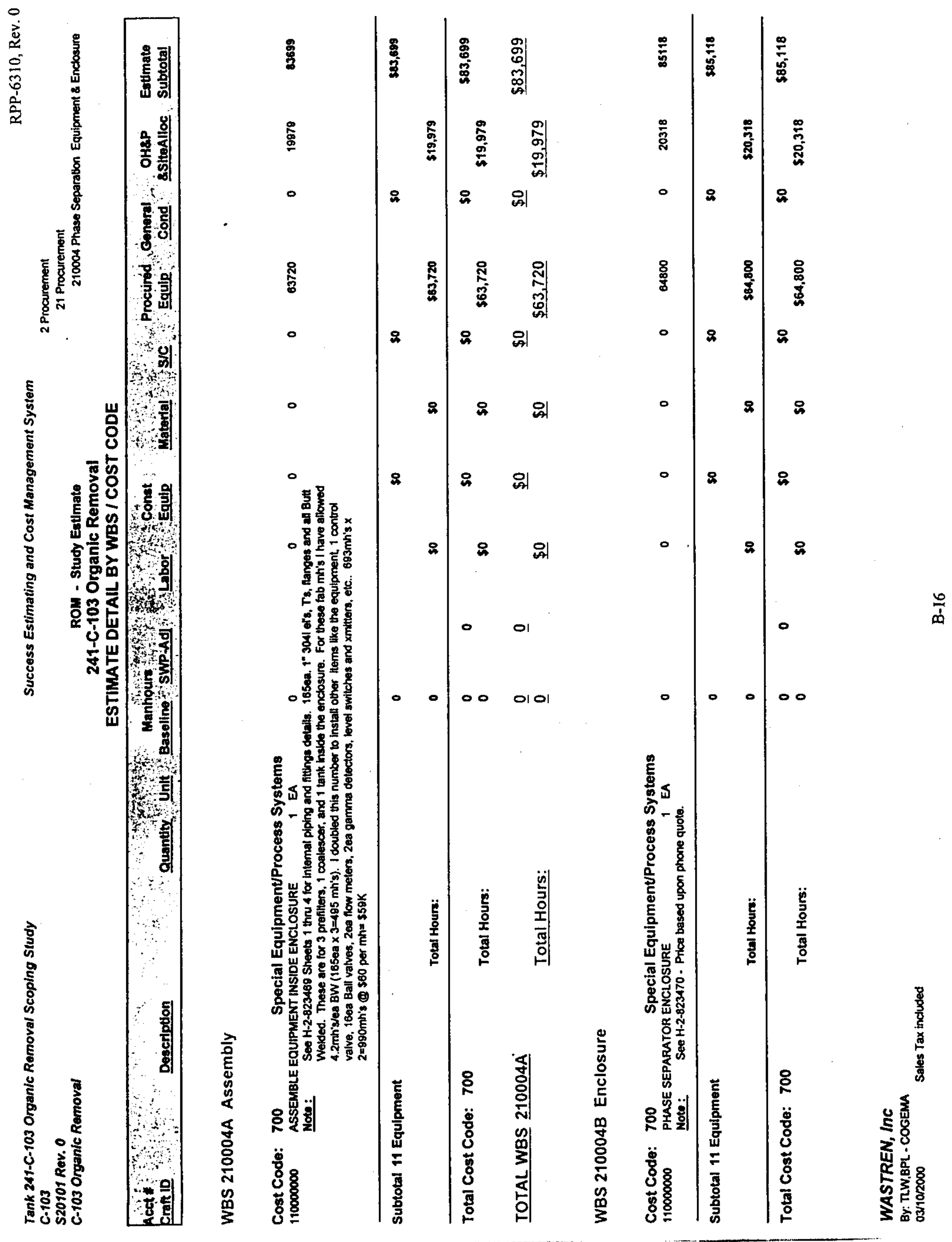




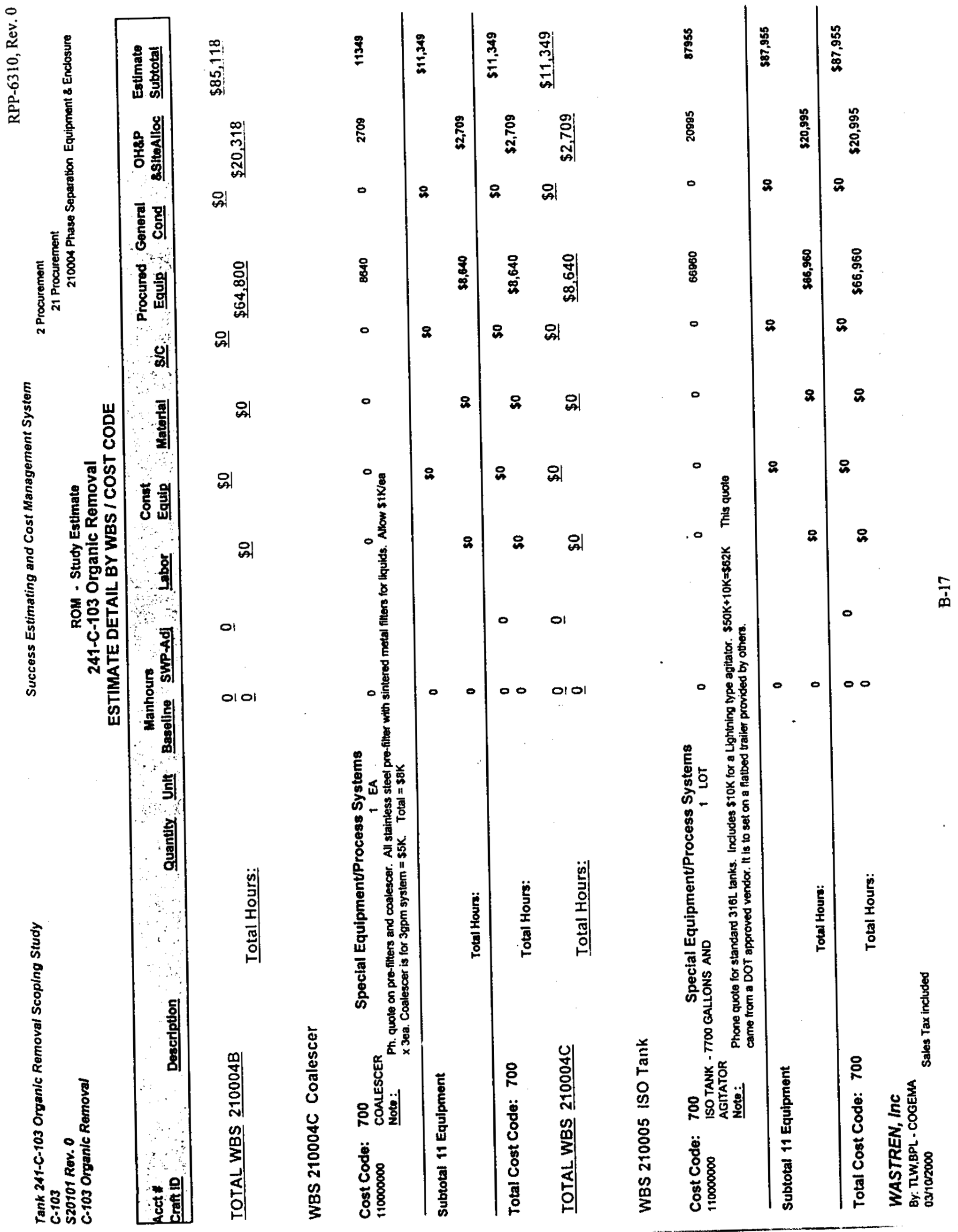




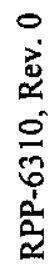

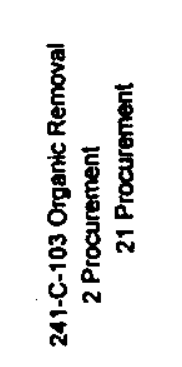

है

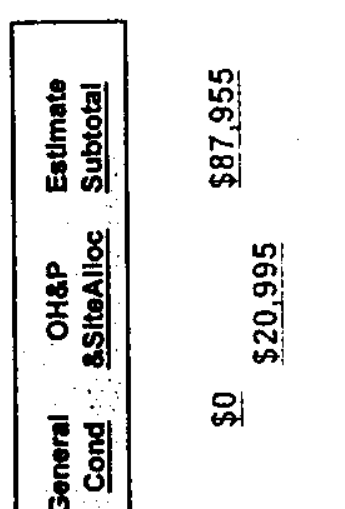

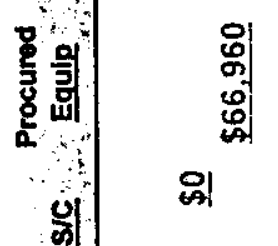

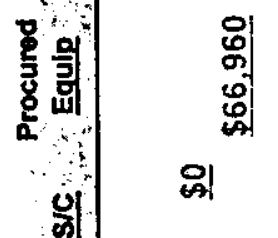

뭫ㅇㅇㅇ

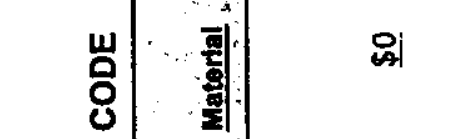

涴占

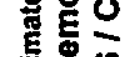

응

잉

하 아

이

웅음

仓ั0

守

䍃

.

क्षे

일

고ํ

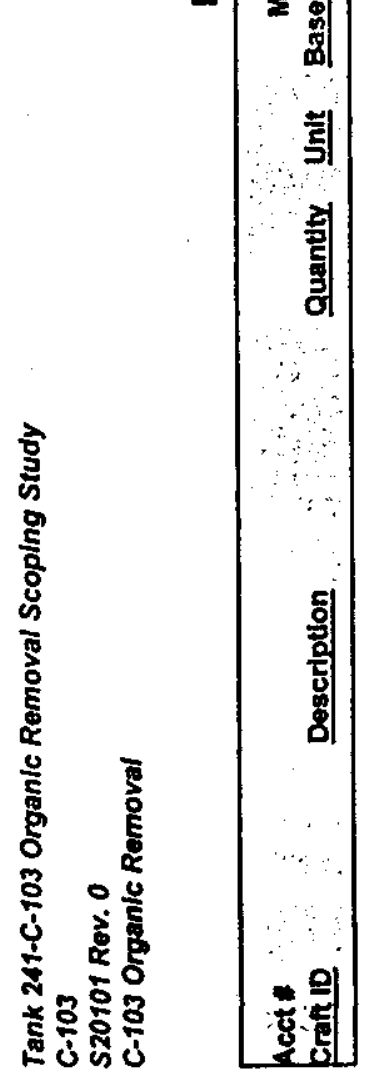

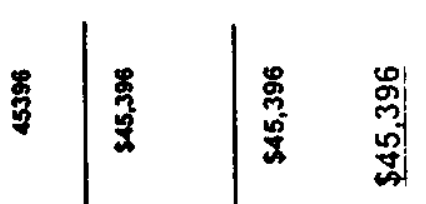

莕

$\begin{array}{ll}0 & 0 \\ 0 & 0 \\ 0 & 0 \\ 0 & 0 \\ 0 & 0\end{array}$

- 요용요 잉

密

总

요 잉

\&

요잉

- 용 영
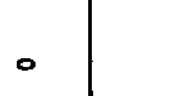

8

요 윆

- 01

跑 ำ

-100.00 0101

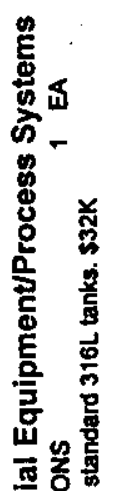

응

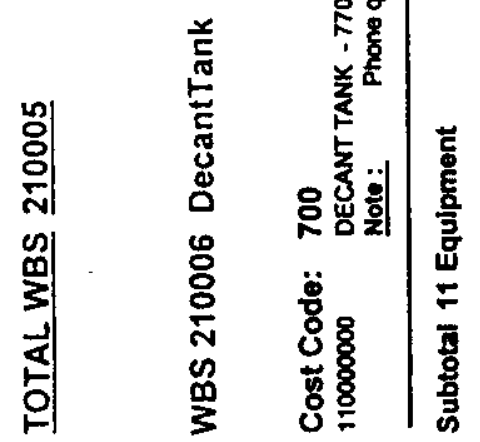

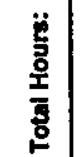

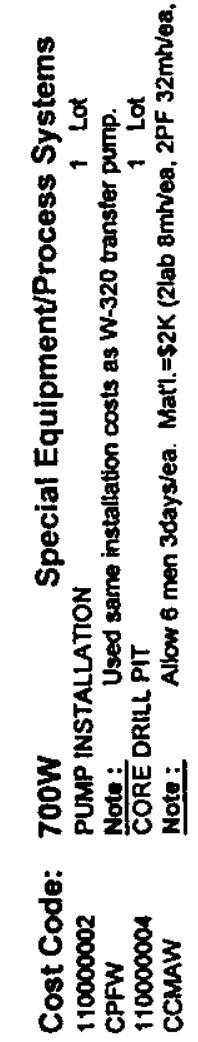

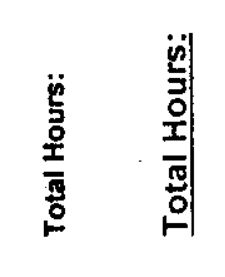

$\frac{\infty}{\infty}$

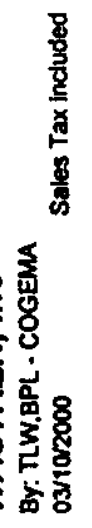




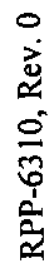

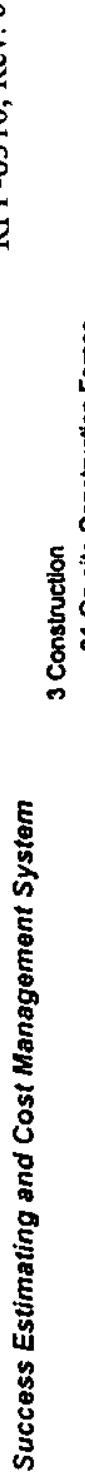

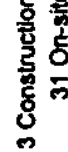

है

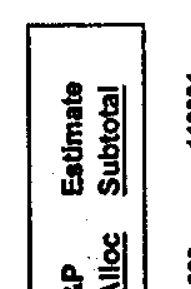

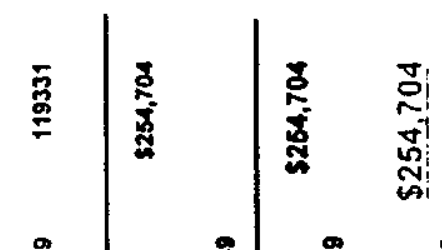

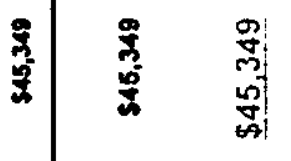

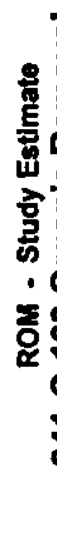

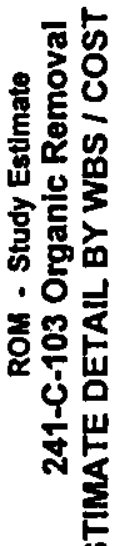

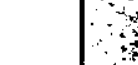

\%

망 휳

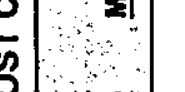

응 氙

8

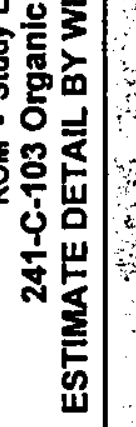

8

4

4
-7

녹

옹

국

㞼

|艹

용에

ڤ

옹 웍

$\frac{8}{6}$

ธ。串

형

-

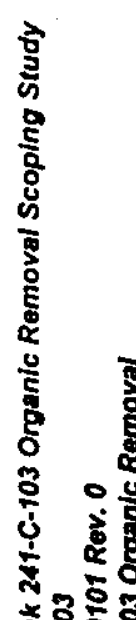

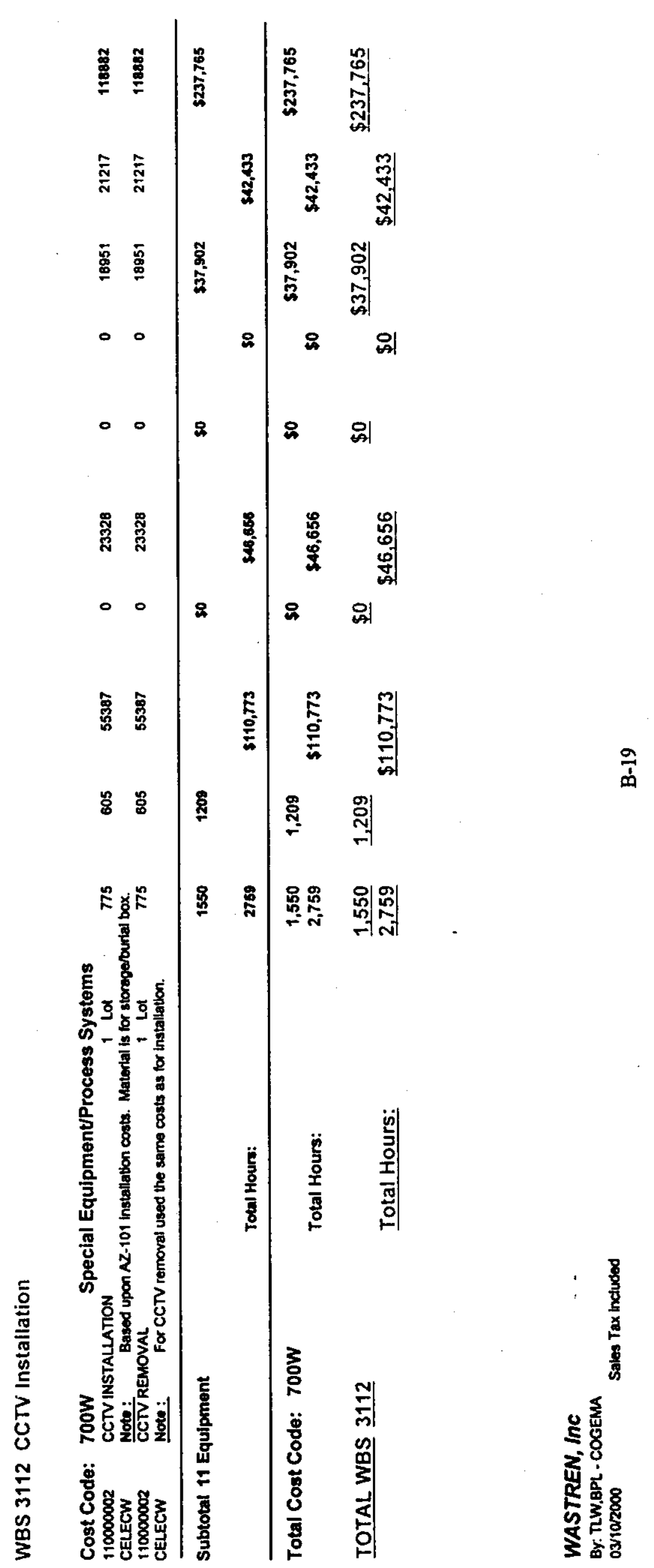




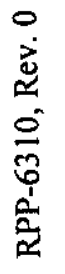

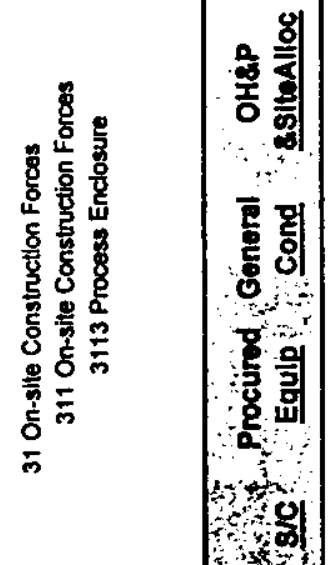

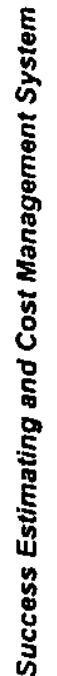

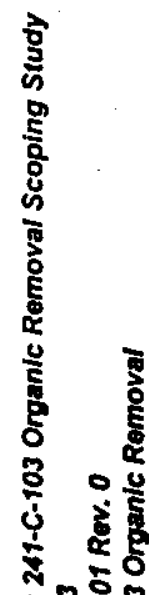

훙ㅇㅇㅇ

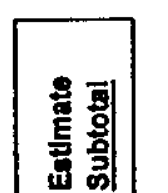

亗 형
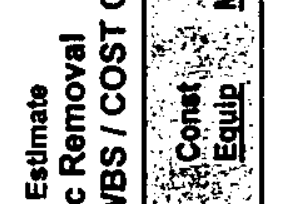

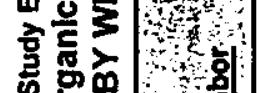

के 물

충용다

出柯司

守岸

跑

点

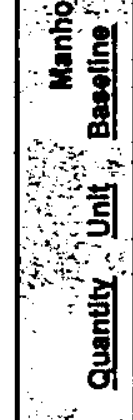
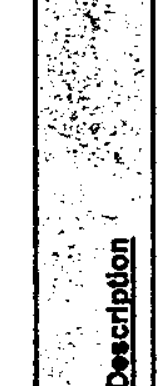

\&

通

을

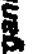

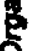
点

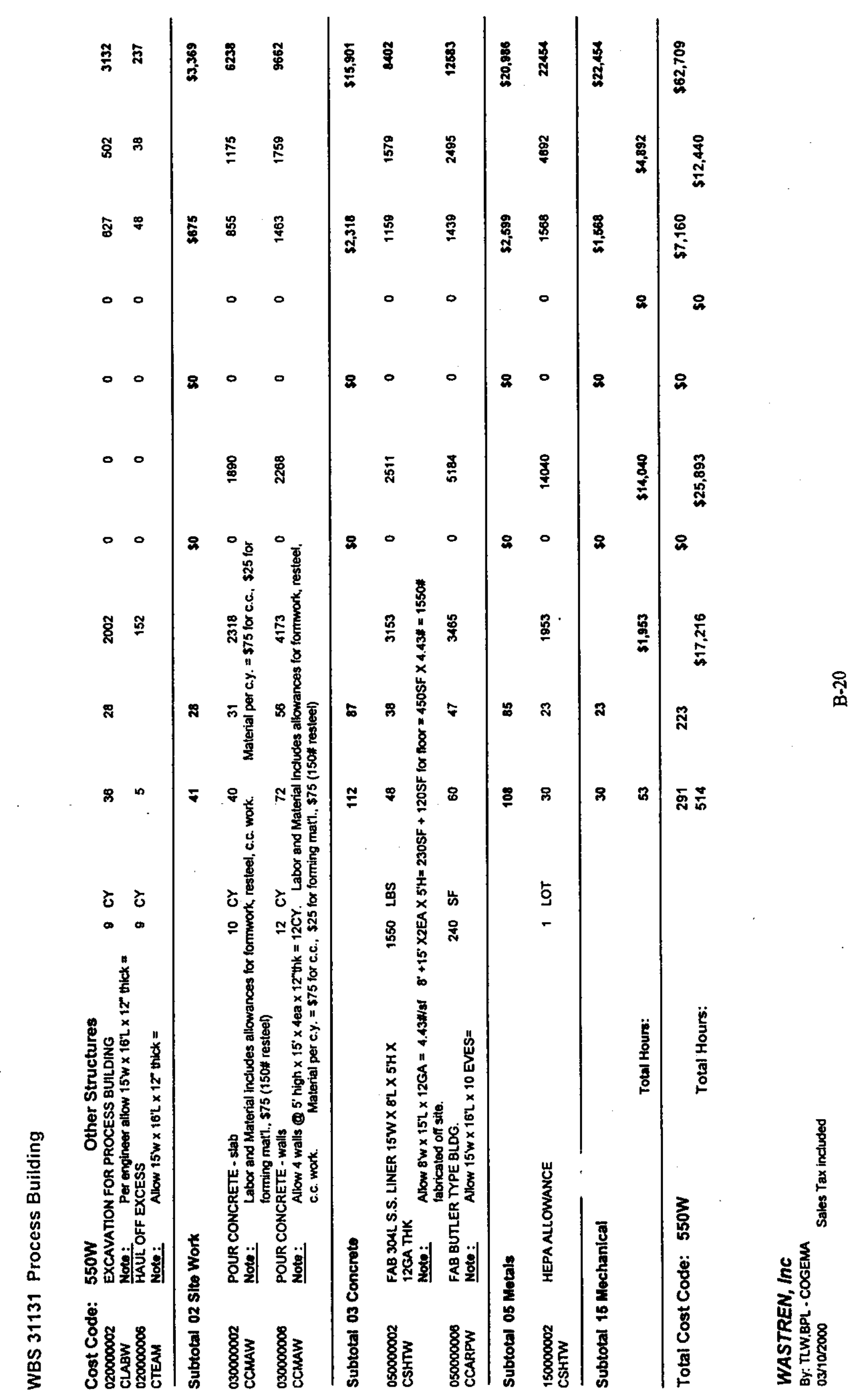




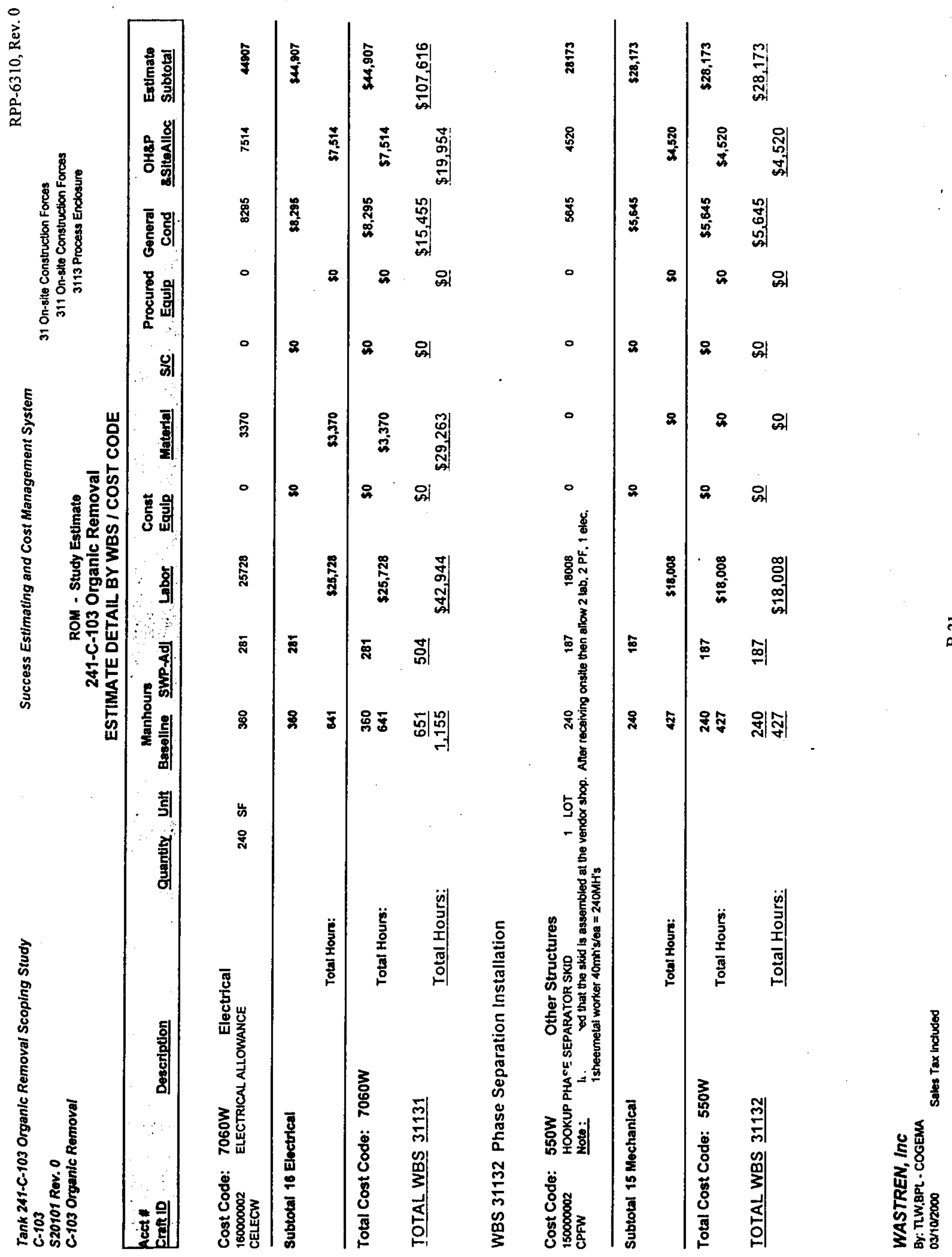




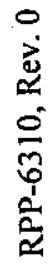

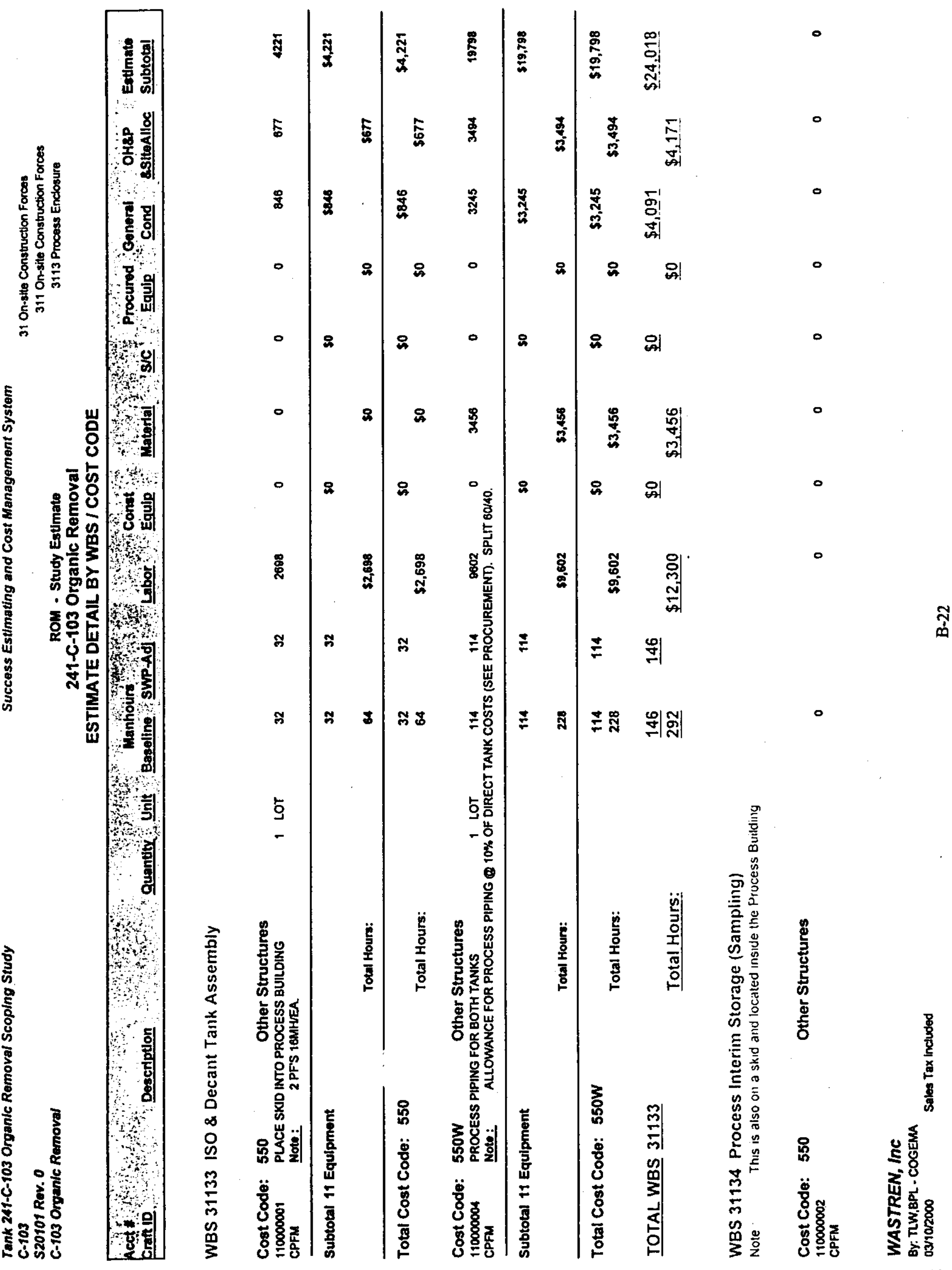




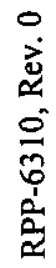


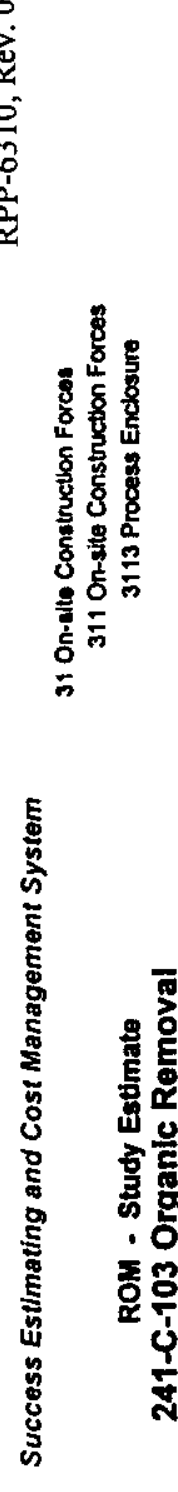
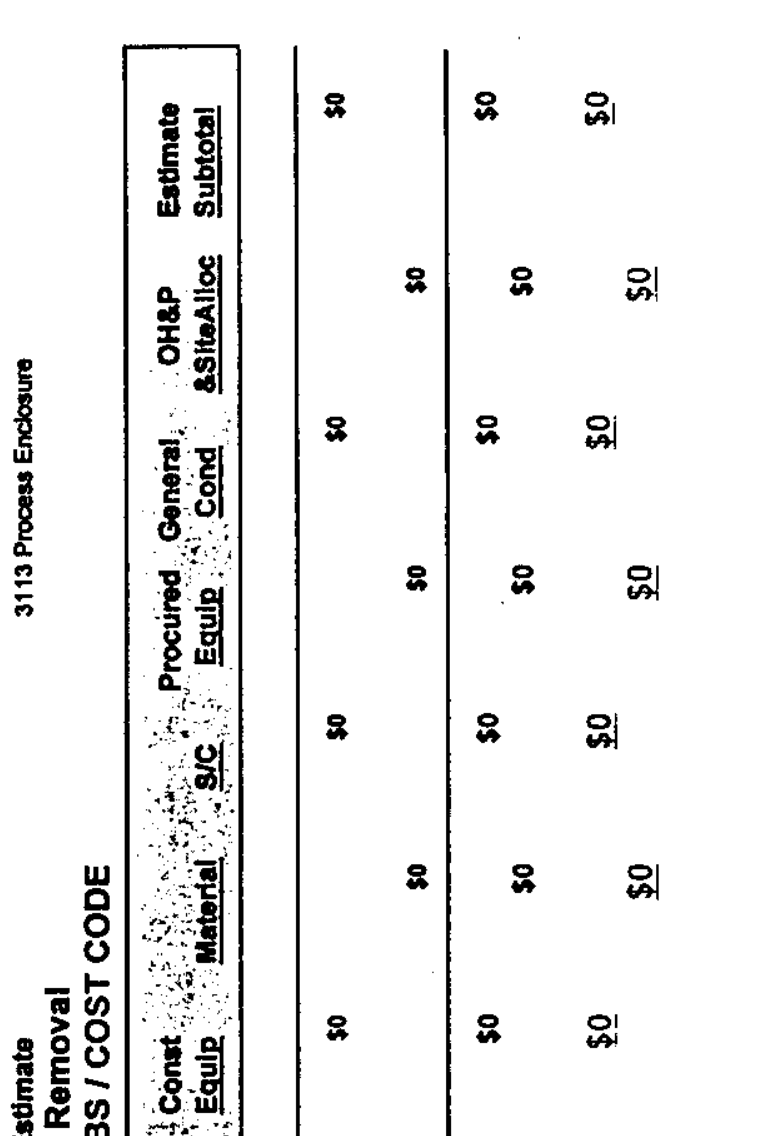

요

요 용 엥

8 용역

용요 익

- 0

동운

Q

तै

它

से

हक

$\frac{9}{5}: \frac{8}{6}$

.

$+2$

1)

w

क

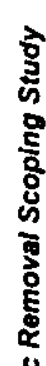

ํㅐㅇ

융

这

훙융 


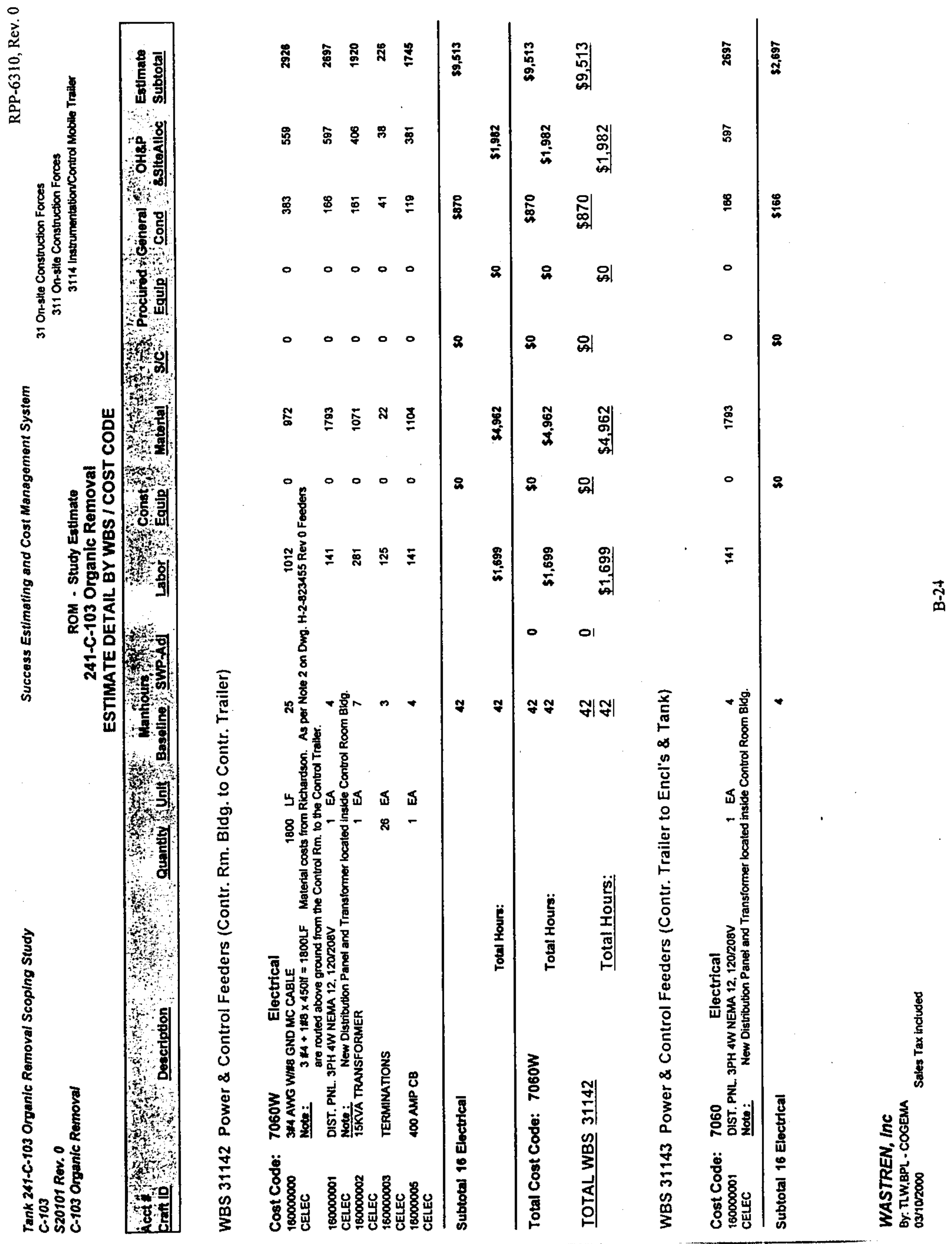




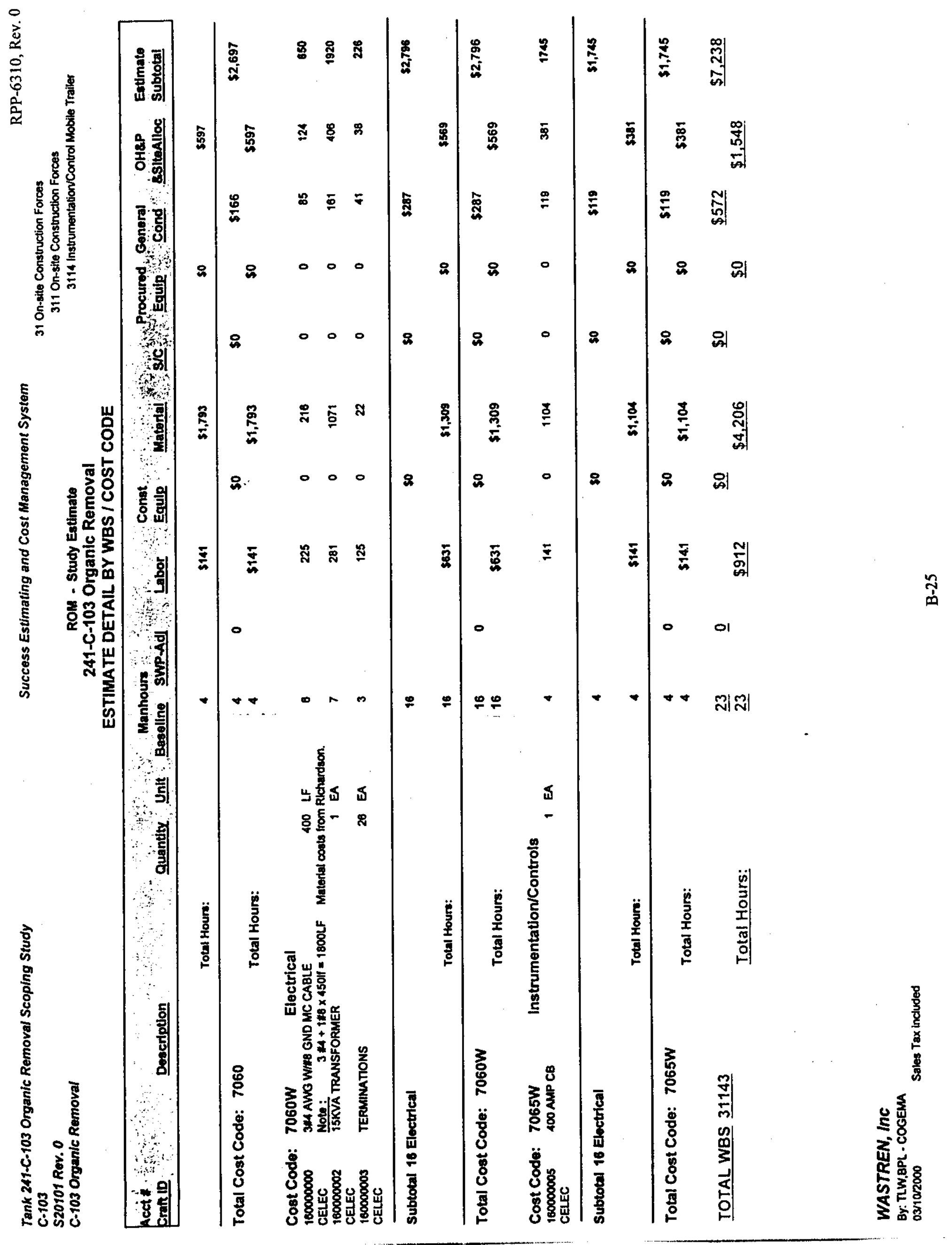




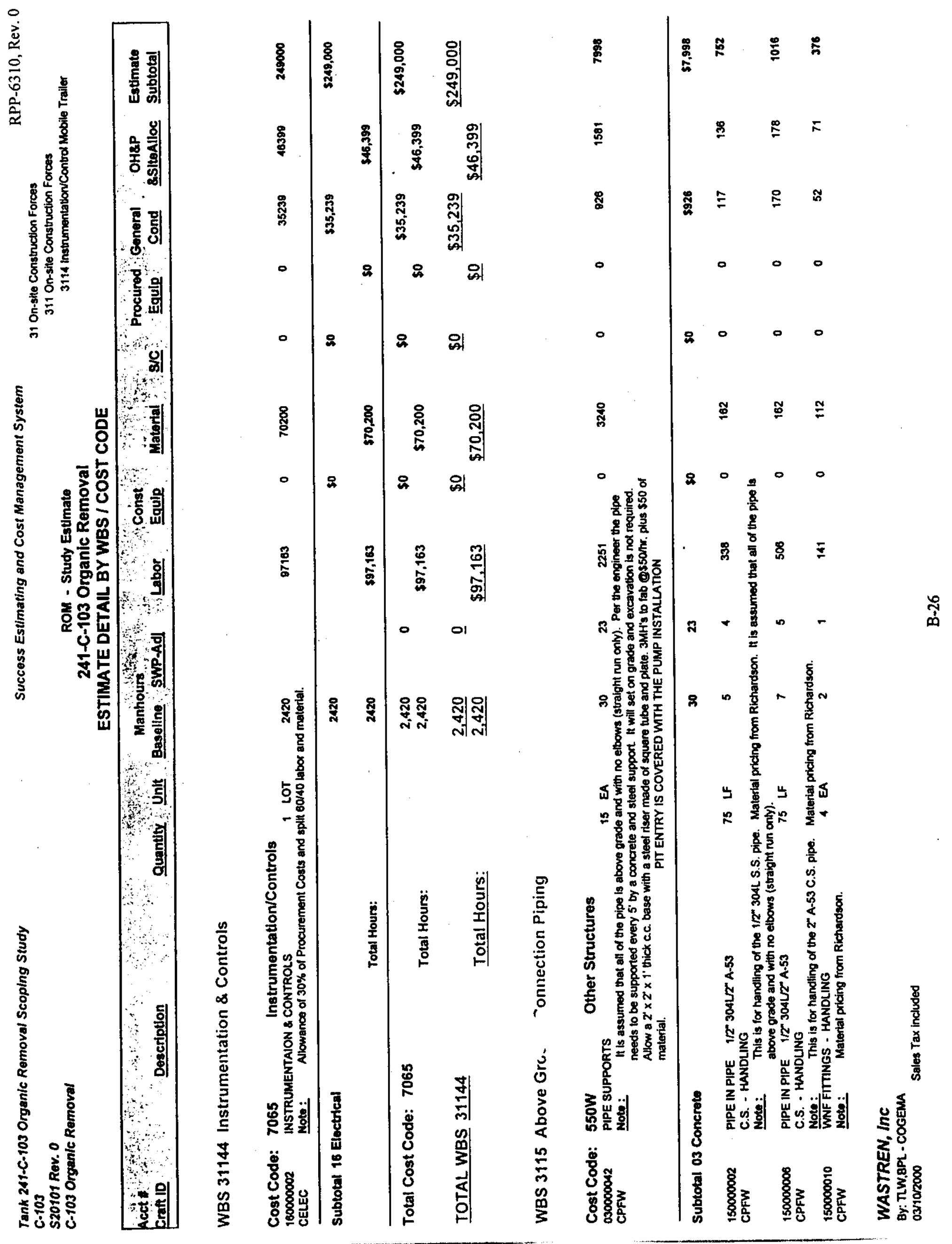




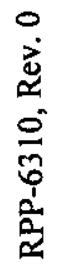

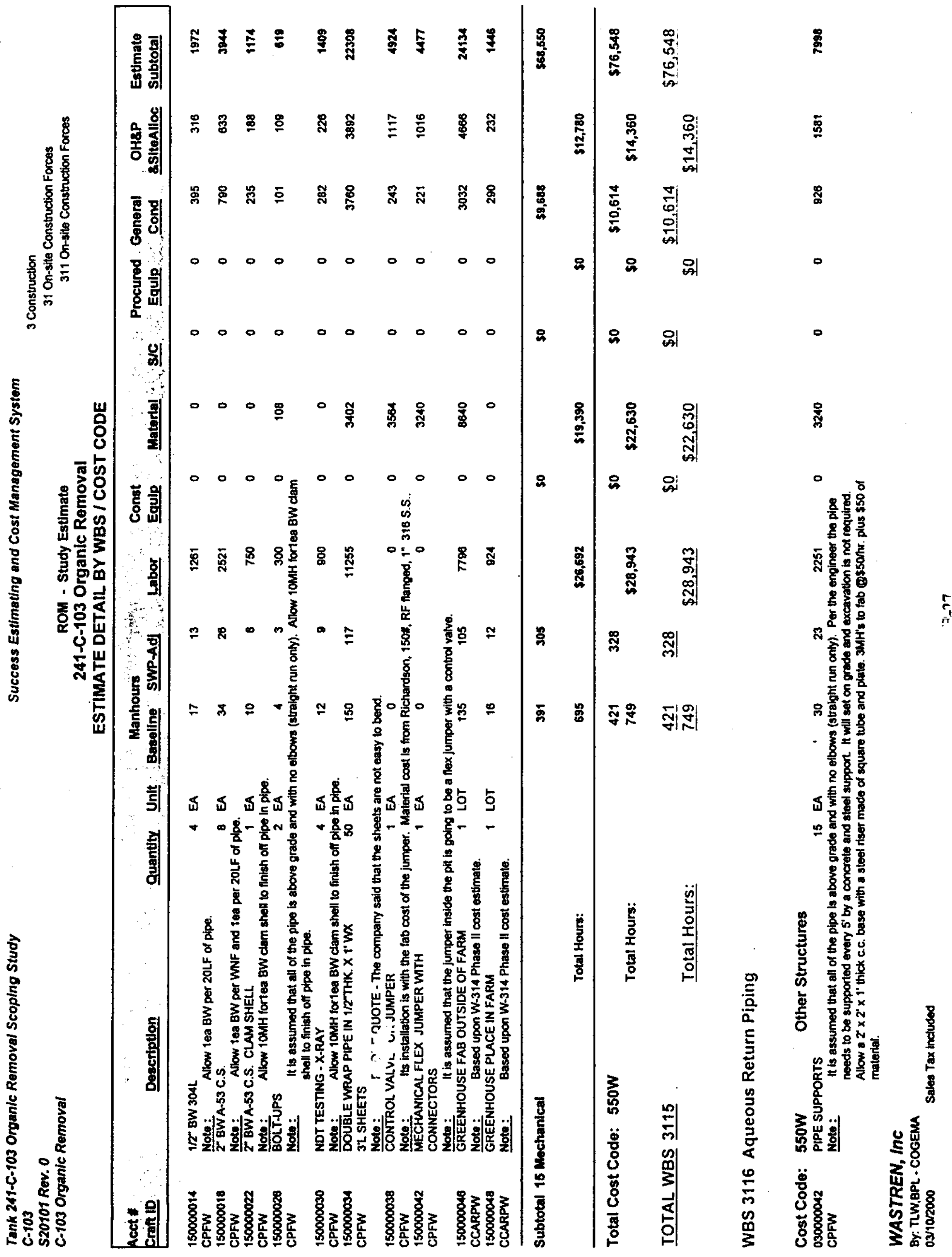




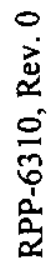

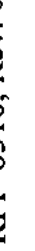

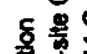

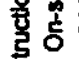

ठํํㅇ

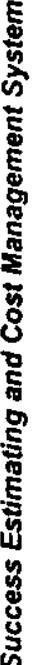

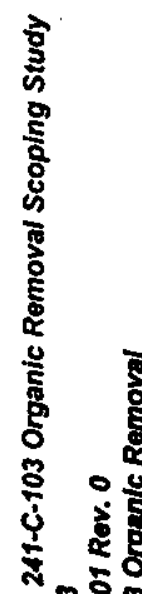

웅융

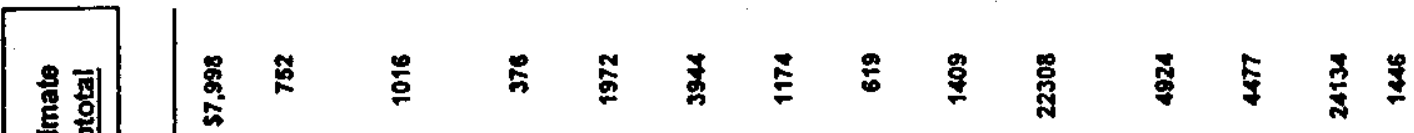

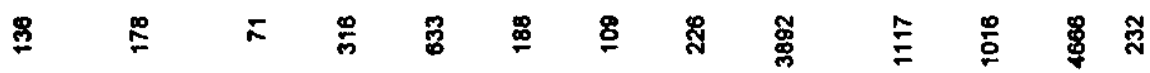

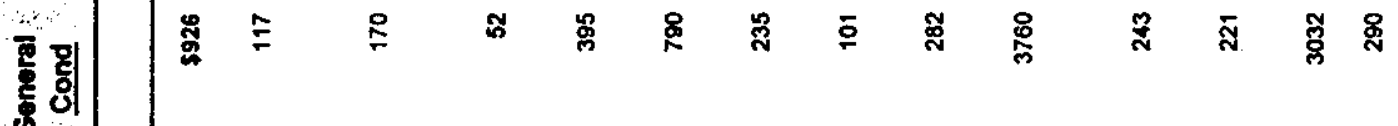



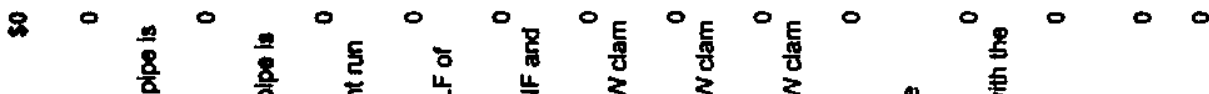

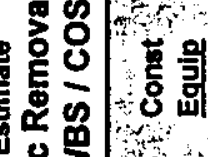

을

क्ष

$0 \Rightarrow$

충응

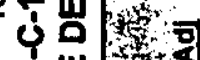

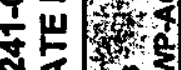

5 की

III

읨

$\therefore$

(1)

단.

6

ty

의

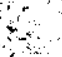

3

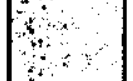

5

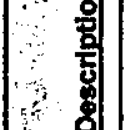

\%

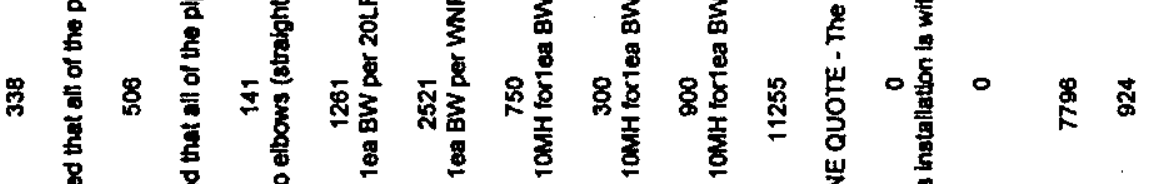

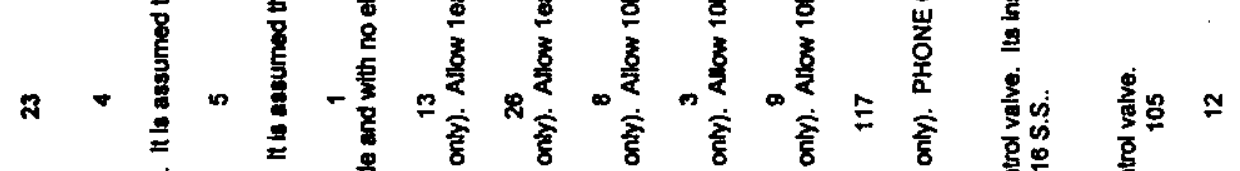

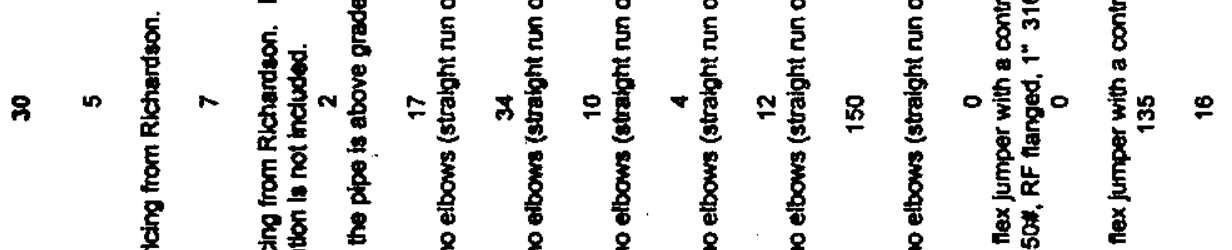

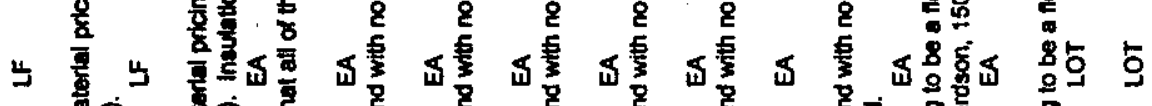

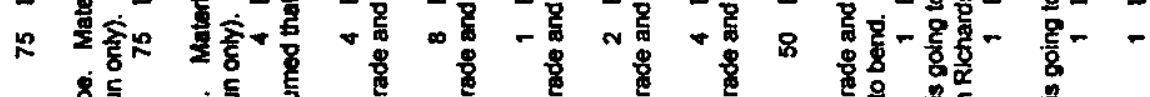

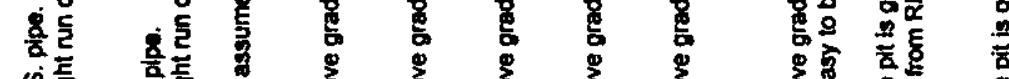

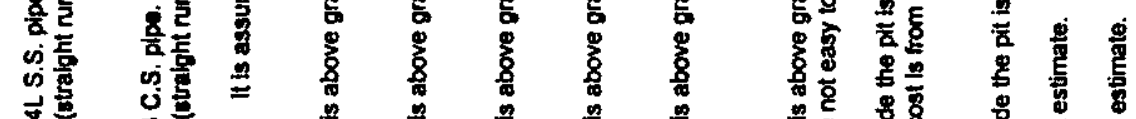

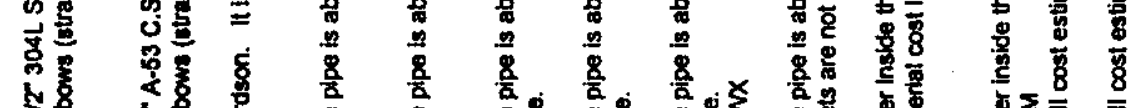

头

\& \&

务

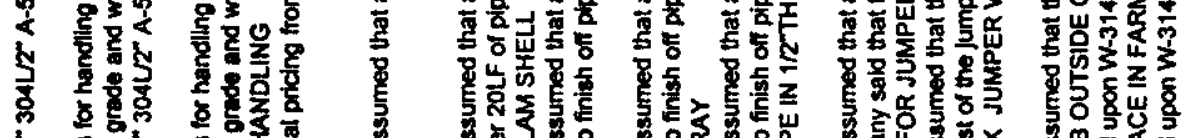

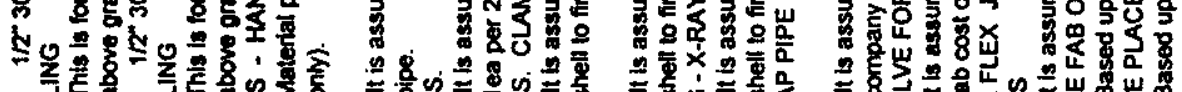

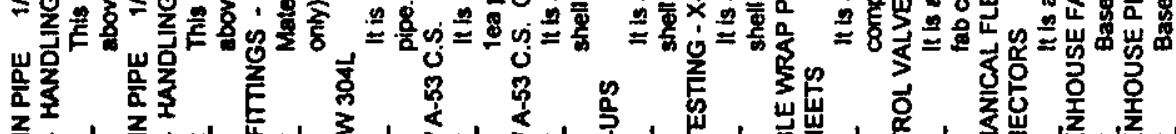
兽 


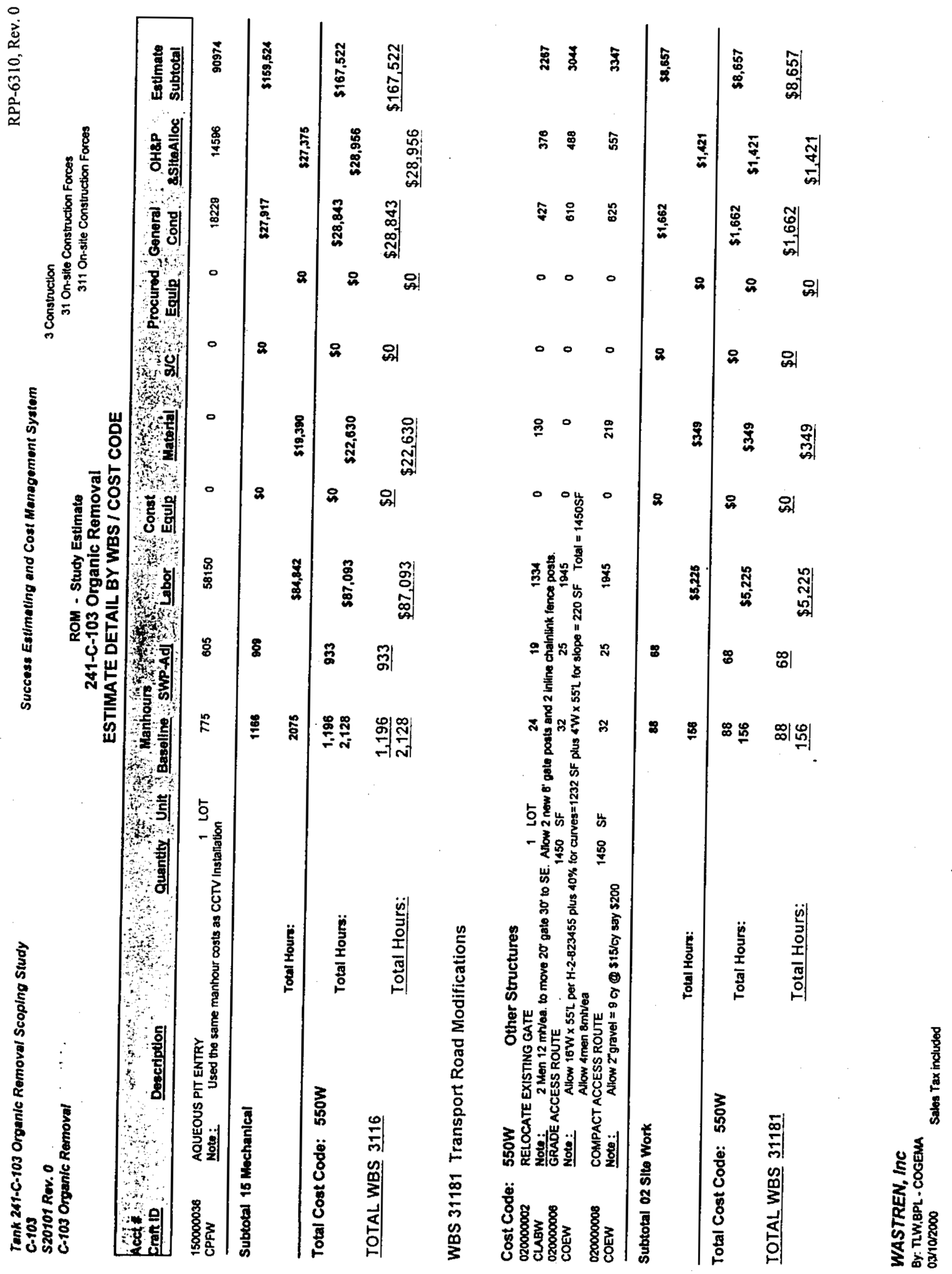




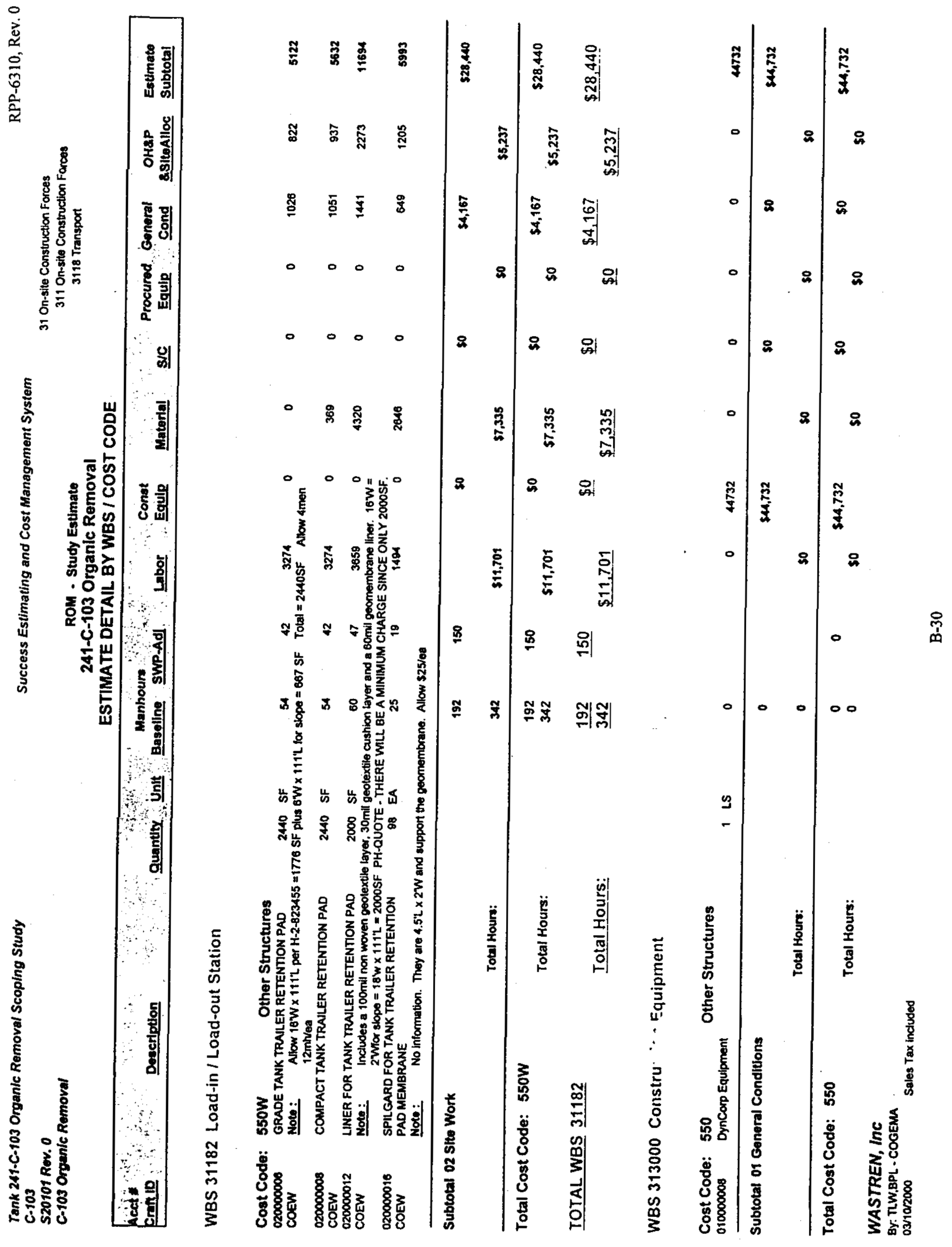




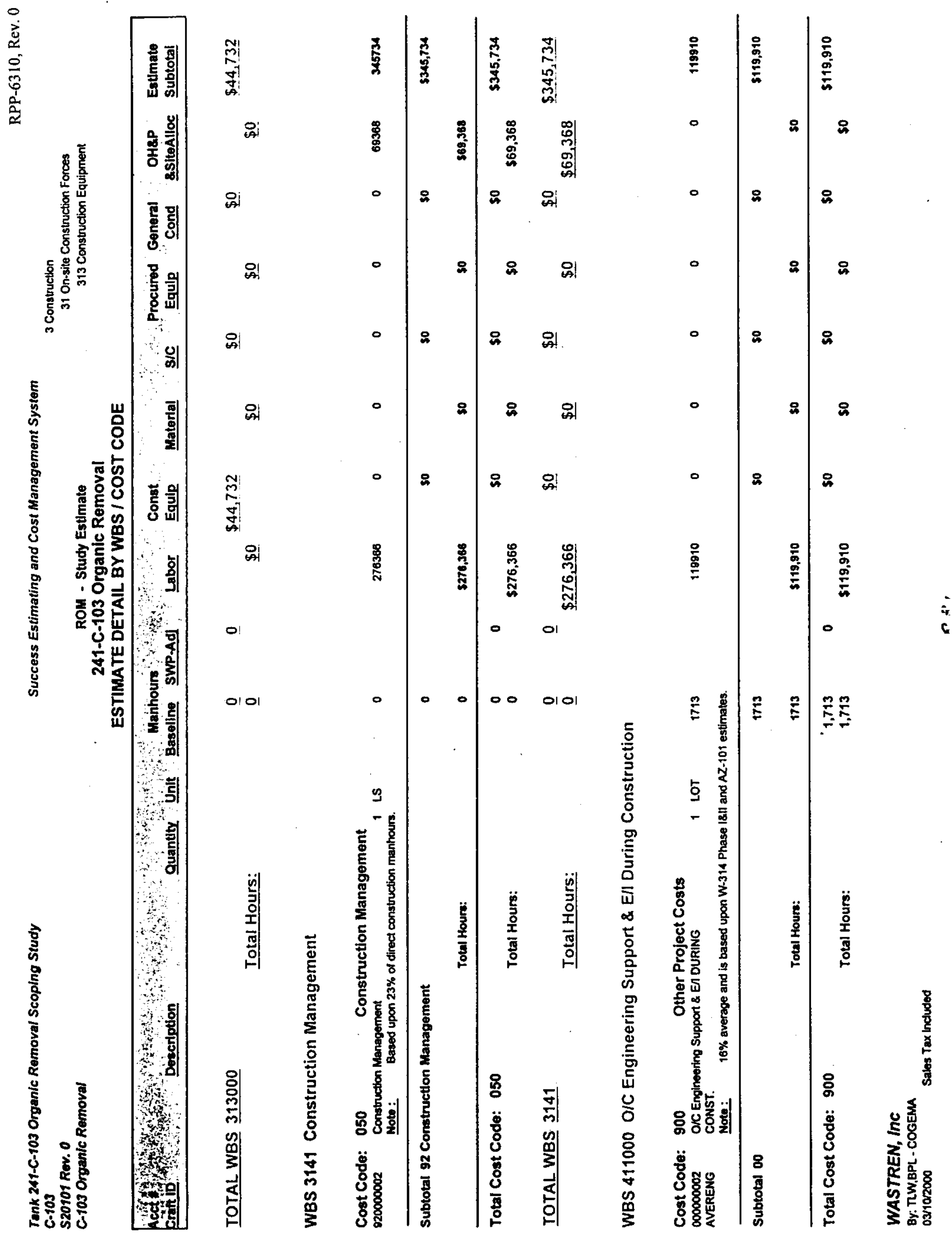


产

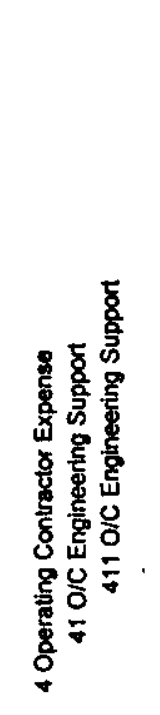

๑
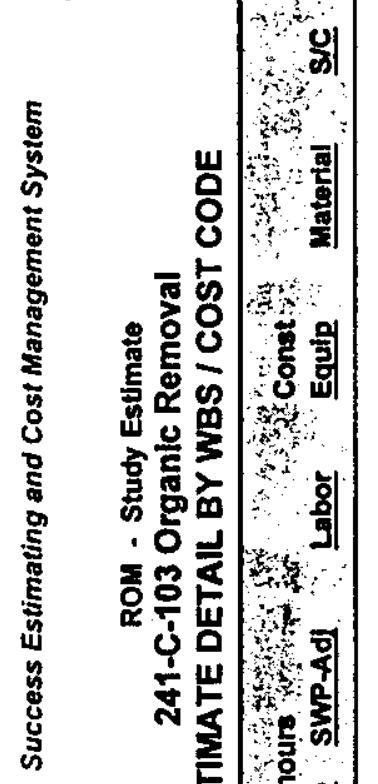

둔 0 崖等

कํㅑㅇ

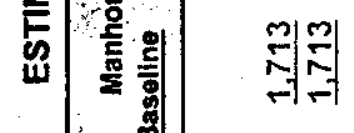

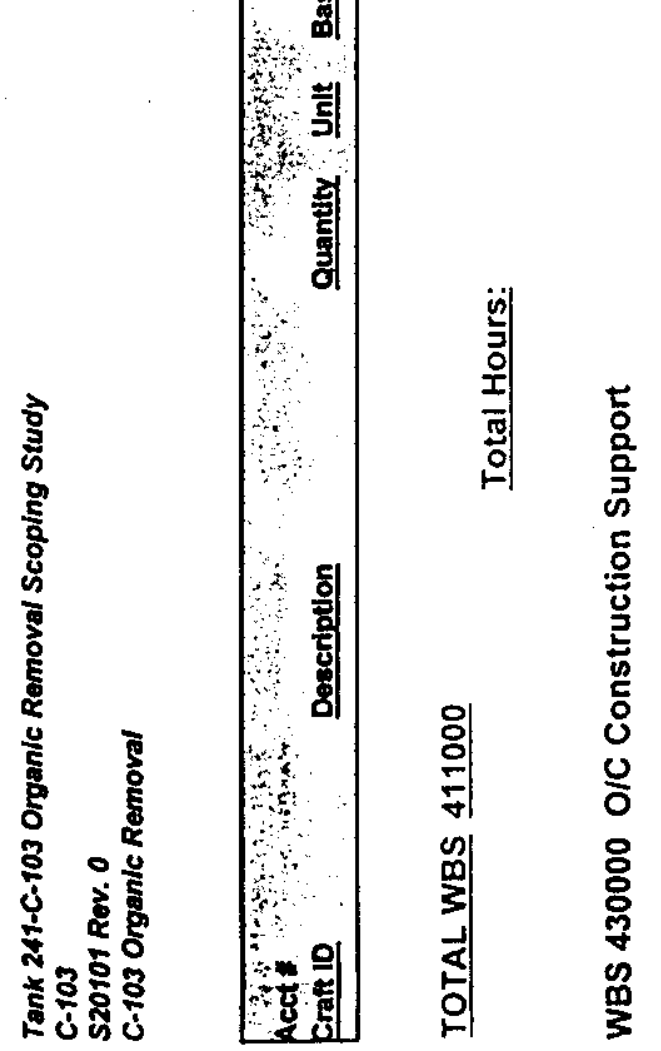

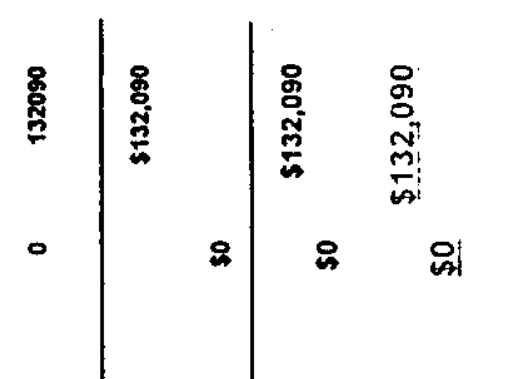

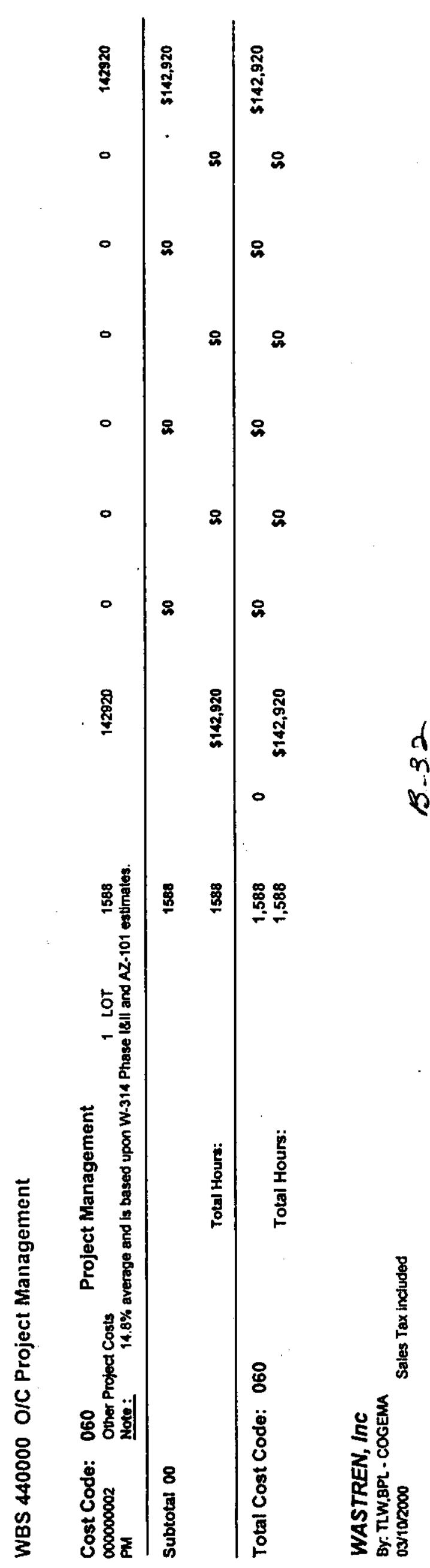




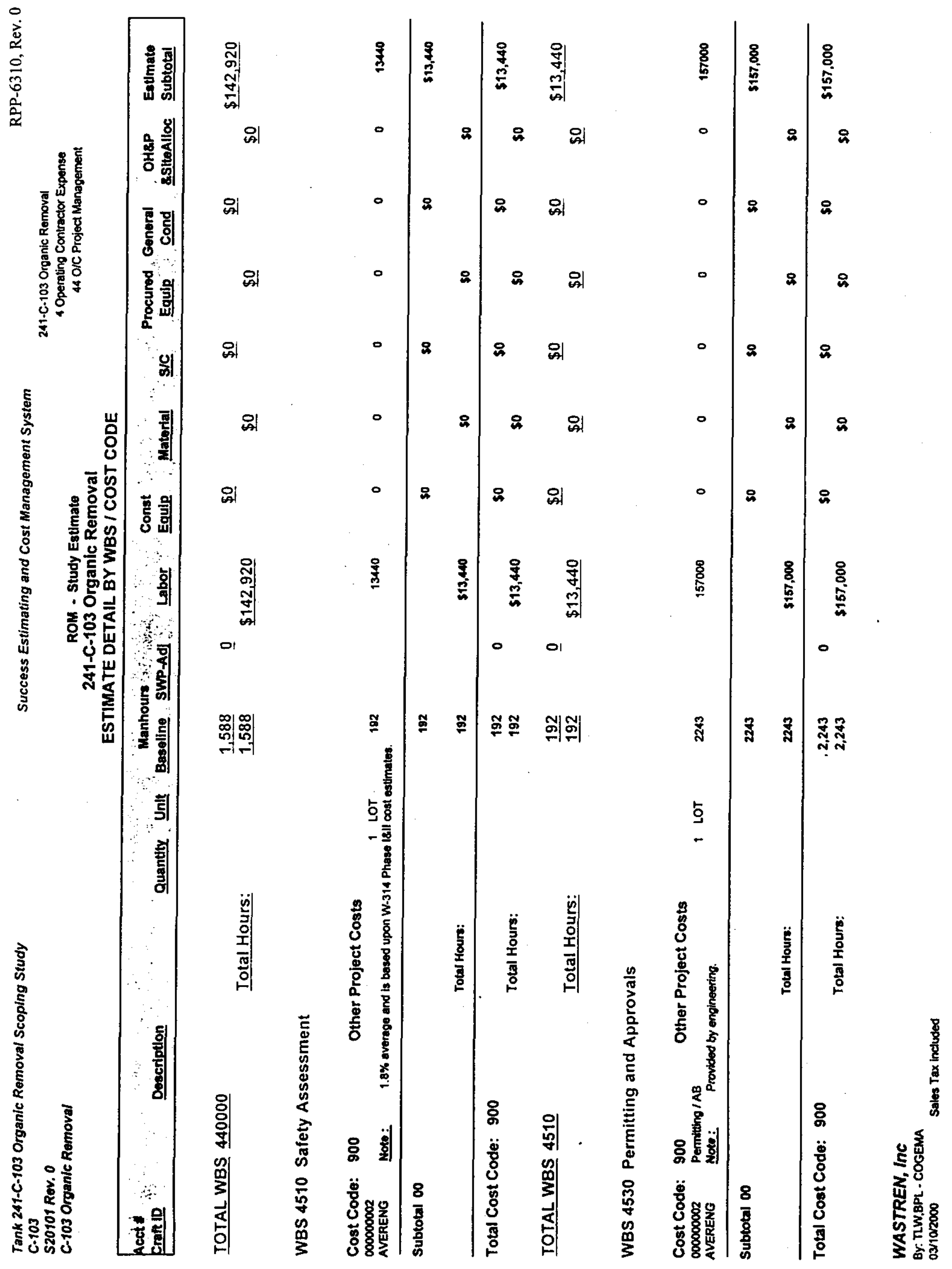




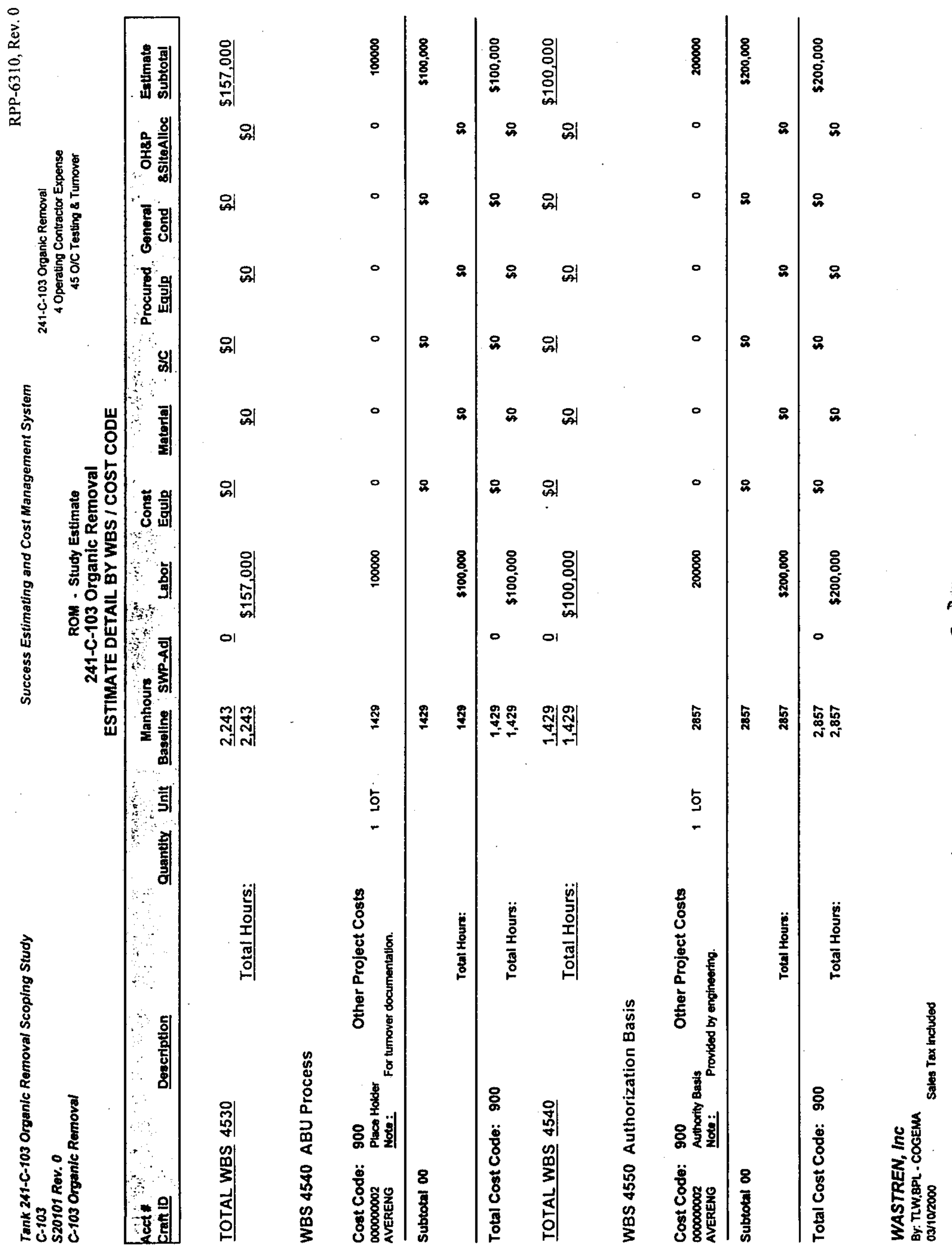




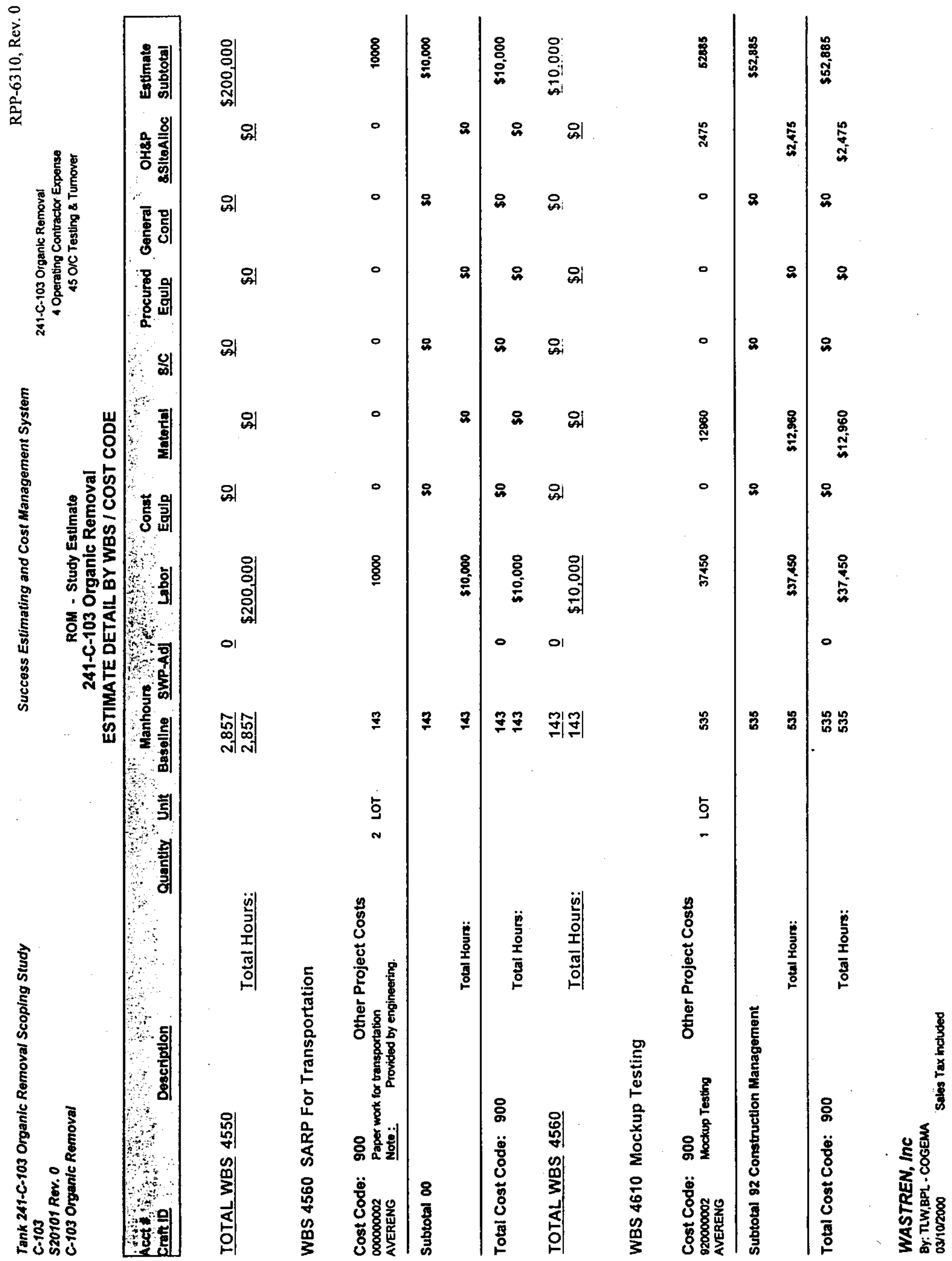


童

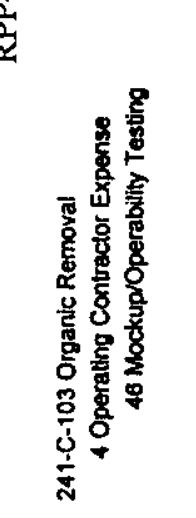

हू

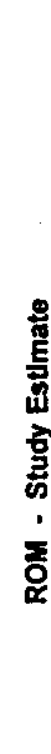

万ั

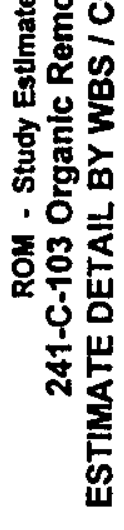

옹워

잉

敌:

o

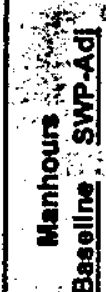

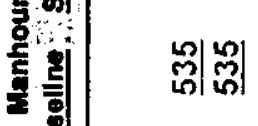

유이

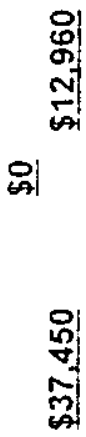

of

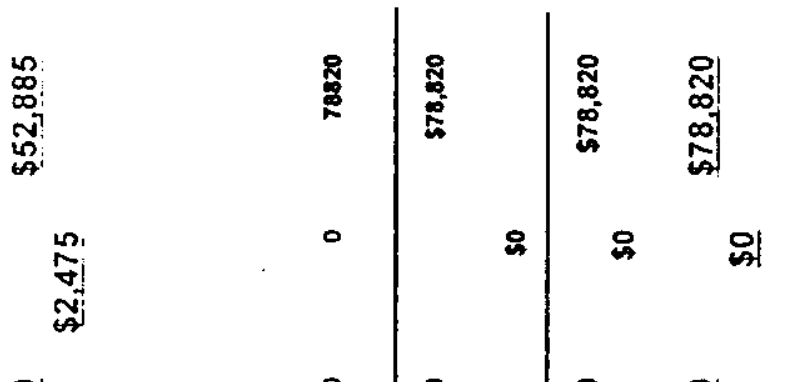

힌

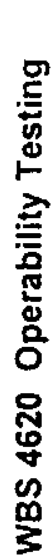

i

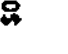

요 융

요 잉

s

요

요 있

悥

幽

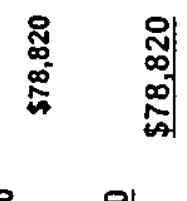

.

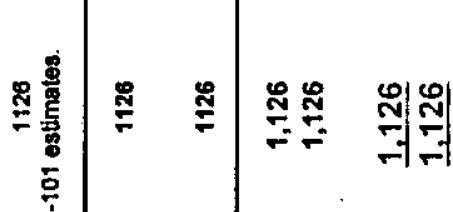

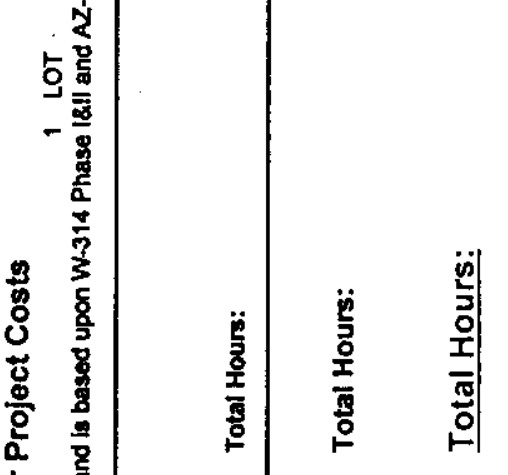

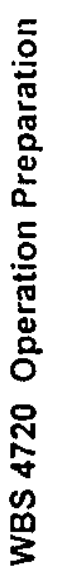

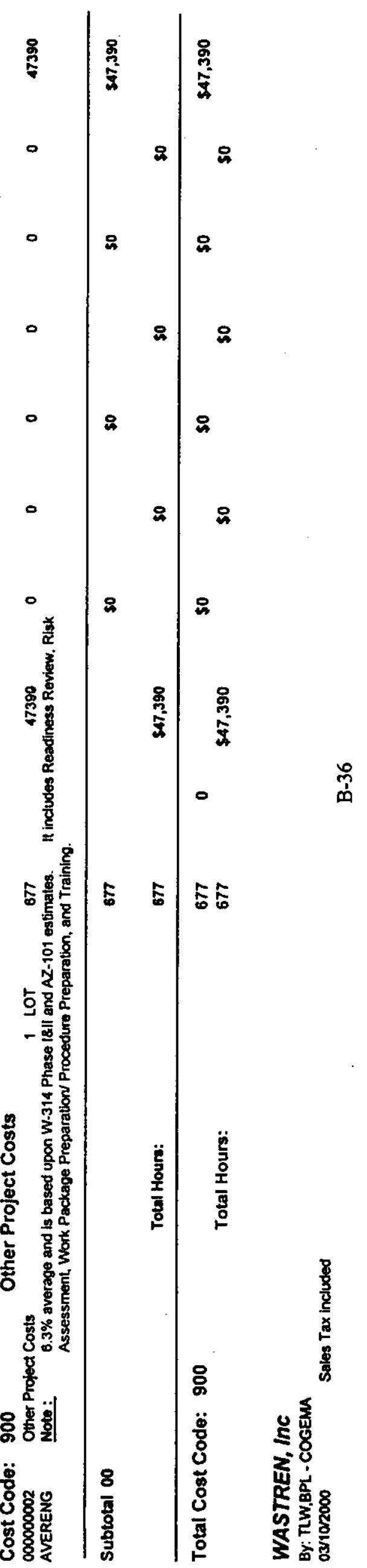




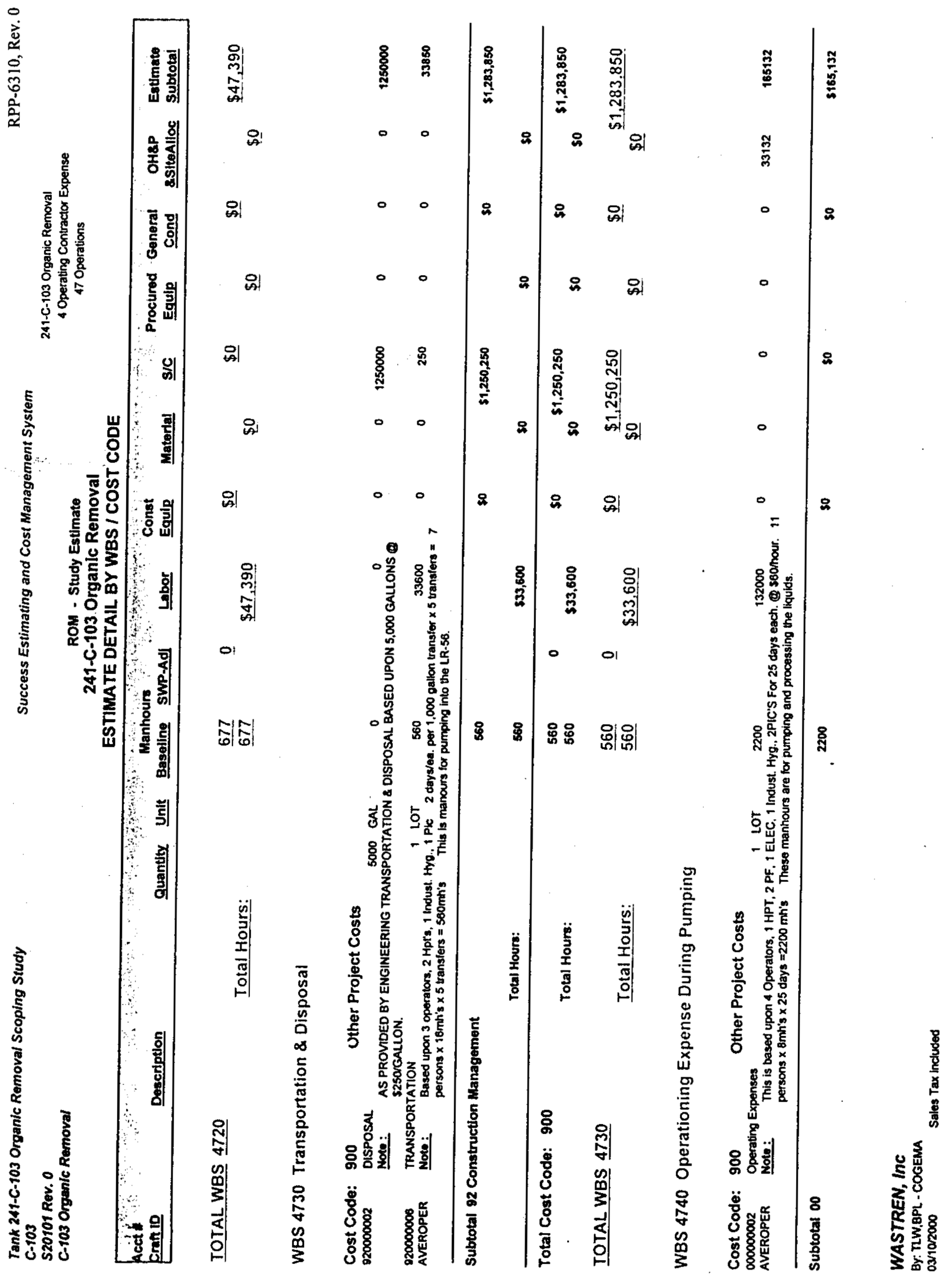




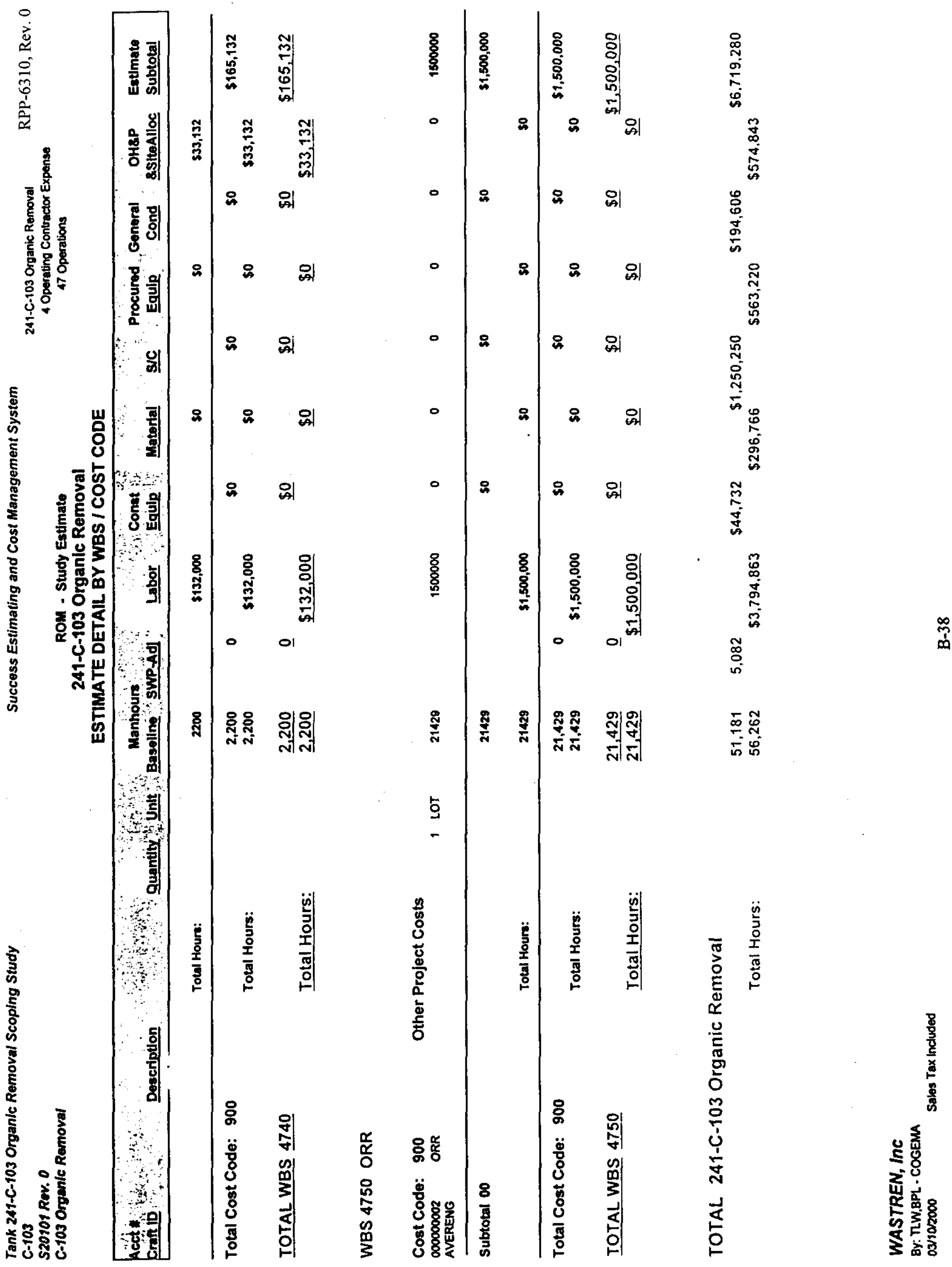




\section{APPENDIX B}

\section{$\operatorname{cosT}$}

\section{LDUA - Light Duty Utility Arm}

The LDUA has been deployed 1 time here at Hanford in Tank T-106 in 1996. The deployment was through a 12" riser (LDUA requires a 12" minimum size riser) and outside of a pit (in other words there was no pit entry). LDUA's reach is about 13.5' in C-103. An end effector has been built to extend another 7 ' in either size tank. The amount of weight that it can pick up is between $50-75$ lbs. The actual costs for the deployment were updated in 1998 and are as follows for 1 deployment (the cost of the arm is not included):

1. Installation $=2$ week mission $=\$ 150 \mathrm{~K}$

This installation however was in a very clean tank farm tank. The costs could go higher in a farm that is highly contaminated.

2. $\quad$ Training $=\$ 75 \mathrm{~K}(4-6$ persons $)$

Training would be $\sim \$ 75 \mathrm{~K}$ or even less if they could round up the crew that was trained on LDUA initially. FMEF is already setup for training and even has an outside area for training in the wind.

3. An ORR would need to be performed on the $1^{\text {st }}$ tank $=\$ 200-\$ 300 \mathrm{~K}$.

This would not be a repeat cost if tanks were cleaned out consecutively and without an extended period of time between entries. An extended period of time would probably require a new readiness assessment each time.

4. End Effectors (about 12ea.) are available. If new ones are required $=\$ 200-\$ 300 \mathrm{~K} / \mathrm{ea}$. The reason that they are so expensive is because the materials must be pedigreed, spark resistant, etc. Some could cost less, in their fabrication, but would be very simple ones.

5. For additional deployments $=\$ 150 \mathrm{~K} /$ ea per riser.

Assuming there are risers available at the right places a 1,000,000 gallon tank would probably only require 4 deployments. More could be required if the risers are not in the right place on the tank.

Note: LDUA's are deployed at ORNL and ID sites. ORNL's cost for deployment is now down to \$50-70K/ea. but are in different type tanks than Hanford. Flam Gas is not an issue there but is at Hanford. 


\section{DRAFT Summary}

First Installation (In clean farm)

Training (4-6 persons)

Operational Readiness Review

3 additional risers (SST)

Burial (200 CF of RMW)
$\$ 150,000$

75,000

300,000

450,000

25,000

\section{Total}

$\$ 1,000,000$

Assume that existing end effectors are adequate for the mission.

Definitive design engineering for Balance Of Plant, escalation, contingency, and overview CCTV's. It should be noted however that the $\$ 150 \mathrm{~K}$ includes installation, 2 weeks of operation, decontamination, and breakdown of equipment. The LUDA system and 9 end effectors is Government Furnished Equipment as it already exists on site. There is a glovebox over the LDUA that allows for end effector changes. There is a spraying system for cleaning. The $\$ 1 \mathrm{M}$ (above) is similar in magnitude to the deployment estimates that were generated for the AX-104 sampling mission for the Hanford Tank Initiative. 
RPP-6310, Rev. 0

APPENDIX C

ENVIRONMENTAL PERMITTING CHECKLIST 


\section{APPENDIX C}

\section{ENVIRONMENTAL PERMITTING CHECKLIST}

\section{INTRODUCTION}

The Environmental Permits, Approvals, and Requirements (EReqs) Checklist is a general purpose tool for identifying environmental standards and determining their applicability to Hanford Site work. The EReqs Checklist is updated as necessary to account for new or changed federal and state regulations, significant permit and approval conditions, and other relevant environmental mandates. Table $\mathrm{C}-1$ of this appendix presents a completed EReqs Checklist, showing the results of the environmental applicability determinations for projects and activities that support removal or organic from 241-C-103. The last column of Table C-1 indicates whether an environmental permit, approval or requirement was found to be potentially applicable to this work.

A substantial body of experience has been gained in obtaining environmental permits and approvals for facilities within the River Protection Project (RPP). In addition to providing a reliable source of scientific and technical expertise, this experience base can be used to help estimate the level of effort needed to satisfy applicable environmental standards. Information about resources and, more importantly, duration's and timeframes associated with different types of environmental actions will be needed when developing cost, schedule, and staffing plans for removal of organic from 241-C-103.

Table C-2 lists significant environmental actions which, based on the draft scoping study received, have been found to be potentially applicable to this activity. For each environmental action, Table C-2 lists various tasks that may be necessary to obtain relevant permits or approvals, or to otherwise demonstrate compliance with applicable standards. For each listed task, the table provides estimates for labor, other costs, and duration:

- Labor represents the approximate number of direct labor hours that experienced, qualified RPP personnel would require, on average, to complete the task. The labor estimates include all staff time and do not allocate effort to types of personnel (e.g., scientist, clerical, and manager).

- Other costs are indicated if significant "purchased" expenses can be anticipated for the particular task. Direct RPP labor hours are not included in the other cost estimates. Other costs may include items such as facilities, equipment, materials, printing, travel, laboratory, subcontractors, and hired services.

- Duration describes the approximate amount of time needed, from start to finish, to complete the task. Duration is generally independent of the labor effort, and in most cases is controlled by external factors such as agency review times, mandatory periods for public notice and/or hearings, or preset approval cycles (e.g., semi-annual permit renewal). Duration's for multiple tasks are not necessarily additive; some tasks are sequential but others may be able to proceed in parallel. 
The information in Table C-2 is intended for managers and planners to use for initial planning purposes and to anticipate significant work, schedule, and resource constraints that may affect their projects and activities. Not all of the identified environmental actions or tasks will be applicable to each particular project or activity, and the estimates only represent "typical" levels of effort. The estimates should be treated as approximations that must be further refined for detailed project- and activity-specific planning.

Estimated Cost For Permitting and Approvals $=\$ 157,640$.

Estimated Cost For Engineering and Readiness Support $=\$ 34,720^{1}$.

Subpart BB - Contingent Cost of $\$ 100 \mathrm{~K}$ include in operation/installation cost during pumping ${ }^{2}$.

K. S. Tollefson, River Protection Project (RPP) Environmental Services, has expertise in the respective environmental programs and can offer additional information about the permitting requirements for $\mathrm{C}-103$ organic removal.

${ }^{1}$ This item is included under Readiness Activity Costs.

${ }^{2}$ This item is assumed as part of the Operational Costs. 
Table C-1. Environmental Permits, Approvals, and Requirements Checklist for Removal of Organic From Tank 241-C-103.

\begin{tabular}{|c|c|c|c|c|c|}
\hline $\begin{array}{l}\text { Environment or } \\
\text { media }\end{array}$ & $\begin{array}{l}\text { Permit, approval or } \\
\text { requirement }\end{array}$ & Citation & Agency & Affected actions & $\begin{array}{l}\text { Potentially } \\
\text { applicable }\end{array}$ \\
\hline \multirow{2}{*}{$\begin{array}{l}\text { National } \\
\text { Environmental } \\
\text { Policy Act and } \\
\text { Related Reviews }\end{array}$} & NEPA Documentation & $\begin{array}{l}40 \text { CFR } 1500 \text { to } 1508 \\
10 \text { CFR } 1021 \\
\text { DOE Order } 451.1 \mathrm{~A}\end{array}$ & $\mathrm{DOE}$ & $\begin{array}{l}\text { Title II Design (Projects); Pro- } \\
\text { curement }\end{array}$ & Yes \\
\hline & $\begin{array}{l}\text { NEPA } 216 \text { Process/ } \\
\text { External Procurement }\end{array}$ & 10 CFR 1021.216 & DOE & $\begin{array}{l}\text { Environmental Critique before } \\
\text { letting external contract }\end{array}$ & No \\
\hline $\begin{array}{l}\text { Washington State } \\
\text { Environmental } \\
\text { Policy Act }\end{array}$ & SEPA Documentation & WAC 197-11 & Ecology & $\begin{array}{l}\text { Actions requiring issuance of } \\
\text { permits, licenses, or other } \\
\text { approvals by state or local } \\
\text { authorities }\end{array}$ & Yes \\
\hline \multirow{7}{*}{$\begin{array}{l}\text { Other Tribal, } \\
\text { Cultural, } \\
\text { Historic, and } \\
\text { Environmental } \\
\text { Planning and } \\
\text { Assessments }\end{array}$} & $\begin{array}{l}\text { American Indian Policies } \\
\text { Review }\end{array}$ & $\begin{array}{l}42 \text { USC } 1966 \\
\text { DOE Order } 1230.2\end{array}$ & $\begin{array}{l}\text { DOE } \\
\text { BIA }\end{array}$ & $\begin{array}{l}\text { Actions impacting tribal } \\
\text { interests, culture, } \\
\text { environment, or resources }\end{array}$ & No \\
\hline & $\begin{array}{l}\text { Cultural Resources } \\
\text { Review }\end{array}$ & $\begin{array}{l}10 \text { CFR } 1021 \\
36 \text { CFR } 63 \\
36 \text { CFR } 800 \\
43 \text { CFR } 7 \\
16 \text { USC } 461-470 \text { aa } \\
42 \text { USC } 1996 \\
42 \text { USC } 4321 \\
\end{array}$ & $\begin{array}{l}\text { DOE } \\
\text { State } \\
\text { Historic } \\
\text { Preservation } \\
\text { Office }\end{array}$ & $\begin{array}{l}\text { Any surface disturbance, } \\
\text { building modifications, or } \\
\text { other actions affecting areas } \\
\text { of archaeological or historic } \\
\text { significance; Facility changes } \\
\text { affecting Historic Register } \\
\text { eligibility }\end{array}$ & Yes \\
\hline & $\begin{array}{l}\text { Ecological Compliance } \\
\text { Review }\end{array}$ & $\begin{array}{l}10 \text { CFR } 1021 \\
50 \text { CFR } 17 \\
50 \text { CFR } 402.6 \\
16 \text { USC } 703-712 \\
16 \text { USC } 1531 \\
\text { DOE Order } 5484.1 \\
\text { WAC 232-12 } \\
\end{array}$ & $\begin{array}{l}\text { USFWS } \\
\text { Ecology }\end{array}$ & $\begin{array}{l}\text { Surface disturbances, } \\
\text { construction, excavation, or } \\
\text { other actions that modify } \\
\text { habitats or could affect } \\
\text { threatened or endangered } \\
\text { species }\end{array}$ & Yes \\
\hline & $\begin{array}{l}\text { Preoperational } \\
\text { Monitoring of Facility or } \\
\text { Site }\end{array}$ & DOE Order 5400.1 & DOE & $\begin{array}{l}\text { Determination of baseline } \\
\text { environmental conditions } \\
\text { prior to new operations }\end{array}$ & Yes \\
\hline & Excavation Permit & 36 CFR 800 & DOE & $\begin{array}{l}\text { Any surface disturbance or } \\
\text { excavation }\end{array}$ & Yes \\
\hline & $\begin{array}{l}\text { DOE Acquisition/ } \\
\text { ES\&H Management }\end{array}$ & 48 CFR 915 and 970 & DOE & $\begin{array}{l}\text { Integrating Projects with } \\
\text { ISMS }\end{array}$ & No \\
\hline & $\begin{array}{l}\text { Price-Anderson } \\
\text { Amendments Act }\end{array}$ & 10 CFR 820 & DOE & $\begin{array}{l}\text { Facility corrections and } \\
\text { operational readiness }\end{array}$ & No \\
\hline All Air Emissions & Air Operating Permit & WAC $173-401$ & $\begin{array}{l}\text { Ecology } \\
\text { EPA } \\
\text { WDOH }\end{array}$ & $\begin{array}{l}\text { Construction or operations } \\
\text { with potential to emit } \\
\text { regulated compounds to air }\end{array}$ & Yes \\
\hline \multirow[t]{2}{*}{$\begin{array}{l}\text { Radioactive } \\
\text { Air Emissions }\end{array}$} & $\begin{array}{l}\text { Source Review/NOC; } \\
\text { NESHAPs }\end{array}$ & 40 CFR 61, Subpart H & EPA & $\begin{array}{l}\text { Construction or operations } \\
\text { with potential to emit } \\
\text { radionuclides }\end{array}$ & Yes \\
\hline & $\begin{array}{l}\text { Source Review/NOC; } \\
\text { Radionuclides and } \\
\text { BARCT/ALARACT } \\
\end{array}$ & WAC $246-247$ & WDOH & $\begin{array}{l}\text { Construction or operations } \\
\text { with potential to emit } \\
\text { radionuclides }\end{array}$ & Yes \\
\hline \multirow[t]{4}{*}{$\begin{array}{l}\text { Nonradioactive } \\
\text { Air Emissions }\end{array}$} & $\begin{array}{l}\text { Prevention of } \\
\text { Significant } \\
\text { Deterioration } \\
\end{array}$ & WAC $173-400$ & Ecology & $\begin{array}{l}\text { Construction or operations } \\
\text { with potential to degrade } \\
\text { existing air quality }\end{array}$ & Yes \\
\hline & New Source Review & WAC $173-400$ & Ecology & $\begin{array}{l}\text { Construction of new sources } \\
\text { and modification of existing } \\
\text { sources of air emissions }\end{array}$ & Yes \\
\hline & $\begin{array}{l}\text { Toxic Air Pollutants; } \\
\text { NOC and T-BACT }\end{array}$ & WAC $173-460$ & Ecology & $\begin{array}{l}\text { Construction or operations } \\
\text { with potential to emit TAPs }\end{array}$ & Yes \\
\hline & $\begin{array}{l}\text { Outdoor/Unconfined } \\
\text { Burning; Burn Permit }\end{array}$ & $\begin{array}{l}\text { WAC } 173-425 \\
\text { BCAA Reg. 1, Article } 5\end{array}$ & $\begin{array}{l}\text { Hanford Fire } \\
\text { Department } \\
\text { BCAA }\end{array}$ & Open burning & No \\
\hline
\end{tabular}


Table C-1. Environmental Permits, Approvals, and Requirements Checklist for Removal of Organic From Tank 241-C-103.

\begin{tabular}{|c|c|c|c|c|c|}
\hline $\begin{array}{c}\text { Environment or } \\
\text { media }\end{array}$ & $\begin{array}{c}\text { Permit, approval or } \\
\text { requirement }\end{array}$ & Citation & Agency & Affected actions & $\begin{array}{l}\text { Potentially } \\
\text { applicable }\end{array}$ \\
\hline \multirow[t]{2}{*}{$\begin{array}{l}\text { Drinking Water } \\
\text { Supply }\end{array}$} & $\begin{array}{l}\text { System ID Number; } \\
\text { Engineer Report, Plans } \\
\text { and Specifications }\end{array}$ & WAC $246-290$ & WDOH & $\begin{array}{l}\text { Construction or operation of a } \\
\text { source for public or worker } \\
\text { drinking water }\end{array}$ & No \\
\hline & Operator Certification & WAC 246-292 & WDOH & $\begin{array}{l}\text { Operation of a drinking water } \\
\text { supply }\end{array}$ & No \\
\hline \multirow[t]{4}{*}{$\begin{array}{l}\text { Domestic Waste } \\
\text { Water Disposal }\end{array}$} & $\begin{array}{l}\text { Septic Systems Design } \\
\text { Approval }\end{array}$ & WAC 246-272 & WDOH & $\begin{array}{l}\text { Construction or operation of } \\
\text { septic disposal systems with } \\
<14,500 \text { gal/day capacity }\end{array}$ & No \\
\hline & $\begin{array}{l}\text { Septic Systems Design } \\
\text { Approval }\end{array}$ & WAC $173-216$ and -240 & Ecology & $\begin{array}{l}\text { Construction or operation of } \\
\text { septic disposal systems with } \\
>14,500 \text { gal/day capacity }\end{array}$ & No \\
\hline & Pretreatment Permit & $\begin{array}{l}40 \text { CFR } 403 \\
\text { WAC } 173-220 \\
\text { City Ordinance } \\
\end{array}$ & $\begin{array}{l}\text { Ecology } \\
\text { City of } \\
\text { Richland }\end{array}$ & $\begin{array}{l}\text { Discharge of waste water to } \\
\text { public sanitary sewage } \\
\text { treatment system }\end{array}$ & No \\
\hline & $\begin{array}{l}\text { Wastewater Treatment } \\
\text { Facility Permit; } \\
\text { Discharge Standards; } \\
\text { Operator Certification }\end{array}$ & $\begin{array}{l}\text { 40 CFR } 122 \\
\text { WAC } 173-216 \text { and }-240 \\
\text { WAC } 173-221 \\
\text { WAC } 173-230\end{array}$ & $\begin{array}{l}\text { Ecology } \\
\text { EPA }\end{array}$ & $\begin{array}{l}\text { Construction or operation of } \\
\text { facility for treatment and } \\
\text { disposal of sanitary sewage }\end{array}$ & No \\
\hline \multirow{3}{*}{$\begin{array}{l}\text { Waste Water } \\
\text { Disposal to } \\
\text { Ground and Soil } \\
\text { Column }\end{array}$} & $\begin{array}{l}\text { Groundwater Quality } \\
\text { Standards }\end{array}$ & WAC $173-200$ & Ecology & $\begin{array}{l}\text { Disposal of pollutants that } \\
\text { could affect groundwater }\end{array}$ & No \\
\hline & $\begin{array}{l}\text { State Waste Discharge } \\
\text { Permit }\end{array}$ & WAC $173-216$ and -240 & Ecology & $\begin{array}{l}\text { Construction or operation of } \\
\text { facilities that discharge waste } \\
\text { water to ground }\end{array}$ & No \\
\hline & $\begin{array}{l}\text { Underground Injection } \\
\text { Control }\end{array}$ & WAC $173-218$ & Ecology & $\begin{array}{l}\text { Construction or operation of } \\
\text { facilities that dispose of waste } \\
\text { water in underground wells }\end{array}$ & No \\
\hline \multirow{8}{*}{$\begin{array}{l}\text { Construction and } \\
\text { Significant } \\
\text { Actions In or } \\
\text { Near Surface } \\
\text { Water }\end{array}$} & $\begin{array}{l}\text { Floodplain/Wetland } \\
\text { Assessment }\end{array}$ & 10 CFR 1022 & $\mathrm{DOE}$ & $\begin{array}{l}\text { Surface disturbances in } \\
\text { floodplain or near wetlands }\end{array}$ & No \\
\hline & $\begin{array}{l}\text { U.S. Army Corps of } \\
\text { Engineers Permit }\end{array}$ & 33 CFR 325 & USACE & $\begin{array}{l}\text { Construction or operations in } \\
\text { or near a river, lake, or other } \\
\text { surface water }\end{array}$ & No \\
\hline & Nationwide Permits & 33 CFR 330 & USACE & $\begin{array}{l}\text { Construction or operations in } \\
\text { or near a river or waterway }\end{array}$ & No \\
\hline & $\begin{array}{l}\text { Wild \& Scenic River } \\
\text { Section } 10 \text { Permit }\end{array}$ & $\begin{array}{l}33 \text { CFR } 320 \\
33 \text { CFR } 322\end{array}$ & USACE & $\begin{array}{l}\text { Construction or operations in } \\
\text { or near a designated or } \\
\text { candidate wild or scenic river }\end{array}$ & No \\
\hline & $\begin{array}{l}\text { Hanford Reach Study } \\
\text { Act Notification }\end{array}$ & PL 100-605 & $\begin{array}{l}\text { U.S. Park } \\
\text { Service }\end{array}$ & $\begin{array}{l}\text { Construction within } 1 / 4 \text { mile } \\
\text { of the Columbia River }\end{array}$ & No \\
\hline & $\begin{array}{l}\text { Hydraulic Projects } \\
\text { Permit }\end{array}$ & WAC 220-110 & $\begin{array}{l}\text { State Dept. } \\
\text { of Fisheries }\end{array}$ & $\begin{array}{l}\text { Construction or operations in } \\
\text { or near waters of the state }\end{array}$ & No \\
\hline & $\begin{array}{l}\text { Shoreline Development } \\
\text { Permit }\end{array}$ & WAC $173-14$ to -20 & $\begin{array}{l}\text { Benton } \\
\text { County }\end{array}$ & $\begin{array}{l}\text { Construction or operations in } \\
\text { or near waters of the state }\end{array}$ & No \\
\hline & Aquatic Lands Lease & WAC $332-30$ & $\begin{array}{l}\text { State Dept. } \\
\text { of Natural } \\
\text { Resources }\end{array}$ & $\begin{array}{l}\text { Construction or operations in } \\
\text { or near waters of the state }\end{array}$ & No \\
\hline
\end{tabular}


Table C-1. Environmental Permits, Approvals, and Requirements Checklist for Removal of Organic From Tank 241-C-103.

\begin{tabular}{|c|c|c|c|c|c|}
\hline $\begin{array}{c}\text { Environment or } \\
\text { media }\end{array}$ & $\begin{array}{c}\text { Permit, approval or } \\
\text { requirement }\end{array}$ & Citation & Agency & Affected actions & $\begin{array}{l}\text { Potentially } \\
\text { applicable }\end{array}$ \\
\hline \multirow[t]{4}{*}{$\begin{array}{l}\text { Waste Water } \\
\text { Disposal to } \\
\text { Surface Water }\end{array}$} & $\begin{array}{l}\text { NPDES Permit; } \\
\text { Categorical Treatment } \\
\text { Standards }\end{array}$ & $\begin{array}{l}40 \text { CFR } 122 \\
40 \text { CFR } 405 \text { to } 471\end{array}$ & EPA & $\begin{array}{l}\text { Construction or operation of } \\
\text { facilities that treat and dispose } \\
\text { waste water to rivers, lakes, } \\
\text { and other surface waters }\end{array}$ & No \\
\hline & $\begin{array}{l}\text { Certification of NPDES } \\
\text { Permit }\end{array}$ & $\begin{array}{l}40 \text { CFR } 121 \\
\text { WAC } 173-225\end{array}$ & $\begin{array}{l}\text { EPA } \\
\text { Ecology }\end{array}$ & $\begin{array}{l}\text { EPA-issued NPDES permits } \\
\text { must be certified by Ecology }\end{array}$ & No \\
\hline & $\begin{array}{l}\text { Stormwater General } \\
\text { Permit under Waste } \\
\text { Discharge General } \\
\text { Permit Program }\end{array}$ & 40 CFR 122 & EPA & $\begin{array}{l}\text { Construction or operations } \\
\text { that could contribute } \\
\text { pollutants to stormwaters that } \\
\text { discharge to surface water }\end{array}$ & No \\
\hline & $\begin{array}{l}\text { Short-Term Water } \\
\text { Quality Modification } \\
\text { Approval }\end{array}$ & WAC 173-201A & Ecology & $\begin{array}{l}\text { Construction or operations } \\
\text { that could modify the quality } \\
\text { class of a surface water }\end{array}$ & No \\
\hline \multirow{3}{*}{$\begin{array}{l}\text { Radioactive } \\
\text { Materials and } \\
\text { Waste } \\
\text { Management }\end{array}$} & $\begin{array}{l}\text { General Radiation } \\
\text { Protection and } \\
\text { Monitoring Programs }\end{array}$ & $\begin{array}{l}\text { DOE Order } 5400.1 \\
\text { DOE Order } 5400.5 \\
\text { DOE Order } 490\end{array}$ & DOE & $\begin{array}{l}\text { Construction or operations } \\
\text { with potential to emit } \\
\text { radionuclides }\end{array}$ & Yes \\
\hline & $\begin{array}{l}\text { Reprocessing of Spent } \\
\text { Nuclear Fuel }\end{array}$ & $\begin{array}{l}\text { Atomic Energy Act } \\
\text { DOE Order 5820.2A } \\
\text { DOE Order } 6430.1 \mathrm{~A} \\
\text { DOE Order } 435.1 \\
\end{array}$ & DOE & $\begin{array}{l}\text { Construction or operation of } \\
\text { facilities for storing, treating, } \\
\text { processing, and managing } \\
\text { spent nuclear fuel }\end{array}$ & No \\
\hline & $\begin{array}{l}\text { Management of High- } \\
\text { Level and Low-Level } \\
\text { Radioactive Wastes }\end{array}$ & $\begin{array}{l}\text { 10 CFR 962 } \\
40 \text { CFR } 191 \\
\text { DOE Order } 5820.2 \mathrm{~A} \\
\text { DOE Order } 6430.1 \mathrm{~A} \\
\text { DOE Order } 435.1 \\
\end{array}$ & $\begin{array}{l}\text { DOE } \\
\text { EPA } \\
\text { Nuclear } \\
\text { Regulatory } \\
\text { Commission } \\
\end{array}$ & $\begin{array}{l}\text { Construction or operation of } \\
\text { facilities for storing, } \\
\text { packaging, transporting, and } \\
\text { disposing of high and low } \\
\text { level wastes }\end{array}$ & Yes \\
\hline \multirow[t]{6}{*}{$\begin{array}{l}\text { Solid and } \\
\text { Dangerous Waste } \\
\text { Management }\end{array}$} & $\begin{array}{l}\text { Solid Waste Facility } \\
\text { Permit }\end{array}$ & WAC $173-304$ and -351 & $\begin{array}{l}\text { Ecology } \\
\text { Benton- } \\
\text { Franklin } \\
\text { Health Dept. }\end{array}$ & $\begin{array}{l}\text { Construction and operation of } \\
\text { facilities that manage solid } \\
\text { and municipal wastes }\end{array}$ & No \\
\hline & Waste Oils & WAC $173-303$ & Ecology & $\begin{array}{l}\text { Receipt, storage, transport, } \\
\text { recycling, blending, or } \\
\text { burning of waste oils }\end{array}$ & No \\
\hline & $\begin{array}{l}\text { Dangerous Waste Notice } \\
\text { of Intent }\end{array}$ & WAC $173-303-281$ & Ecology & $\begin{array}{l}\text { Expansion, construction, or } \\
\text { modification and operation of } \\
\text { dangerous waste TSD facility }\end{array}$ & No \\
\hline & $\begin{array}{l}\text { Interim Status and Final } \\
\text { Status Standards }\end{array}$ & $\begin{array}{l}\text { WAC } 173-303 \\
40 \text { CFR } 264,265, \text { and } 270\end{array}$ & $\begin{array}{l}\text { Ecology } \\
\text { EPA }\end{array}$ & $\begin{array}{l}\text { Construction, expansion, or } \\
\text { modification of dangerous } \\
\text { waste TSD facility }\end{array}$ & Yes \\
\hline & $\begin{array}{l}\text { Permits for Trials and } \\
\text { Demonstrations }\end{array}$ & $\begin{array}{l}\text { WAC 173-303-807, }-808 \\
\text { and }-809\end{array}$ & Ecology & $\begin{array}{l}\text { Trial burns, land treatment } \\
\text { demonstrations, and research } \\
\text { involving dangerous waste }\end{array}$ & No \\
\hline & $\begin{array}{l}\text { Miscellaneous } \\
\text { Requirements for } \\
\text { Dangerous Waste } \\
\text { Management }\end{array}$ & $\begin{array}{l}\text { WAC 173-303-071 } \\
\text { WAC } 173-303-140 \\
\text { WAC } 173-303-335 \\
\text { WAC } 173-303-610 \\
\text { WAC } 173-303-645 \\
\text { WAC } 173-303-646 \\
\text { 40 CFR } 268\end{array}$ & $\begin{array}{l}\text { Ecology } \\
\text { EPA }\end{array}$ & $\begin{array}{l}\text { Exclusions for treatability test } \\
\text { samples; Land disposal } \\
\text { restrictions; Construction } \\
\text { quality assurance for } \\
\text { dangerous waste } \\
\text { impoundment, pile or landfill; } \\
\text { Partial or final closure of TSD } \\
\text { facility; Monitoring and } \\
\text { corrective actions for } \\
\text { dangerous waste releases }\end{array}$ & Yes \\
\hline
\end{tabular}


Table C-1. Environmental Permits, Approvals, and Requirements Checklist for Removal of Organic From Tank 241-C-103.

\begin{tabular}{|c|c|c|c|c|c|}
\hline $\begin{array}{c}\text { Environment or } \\
\text { media }\end{array}$ & $\begin{array}{l}\text { Permit, approval or } \\
\text { requirement }\end{array}$ & Citation & Agency & Affected actions & $\begin{array}{l}\text { Potentially } \\
\text { applicable }\end{array}$ \\
\hline \multirow{9}{*}{$\begin{array}{l}\text { Hazardous } \\
\text { Substances and } \\
\text { Petroleum } \\
\text { Products }\end{array}$} & Toxic Substances & 40 CFR 720 & EPA & $\begin{array}{l}\text { Activities that produce toxic } \\
\text { substances must submit pre- } \\
\text { manufacturing notification }\end{array}$ & No \\
\hline & $\begin{array}{l}\text { Polychlorinated } \\
\text { Biphenyls }\end{array}$ & 40 CFR 761 & EPA & $\begin{array}{l}\text { Generation and management } \\
\text { of wastes containing regulated } \\
\text { PCBs }\end{array}$ & No \\
\hline & $\begin{array}{l}\text { Ozone Depleting } \\
\text { Substances; Spent } \\
\text { Fluorocarbons; Volatile } \\
\text { Organic Compounds }\end{array}$ & $\begin{array}{l}40 \text { CFR } 82 \\
\text { WAC } 173-303-506 \\
\text { WAC } 173-490\end{array}$ & $\begin{array}{l}\text { EPA } \\
\text { Ecology }\end{array}$ & $\begin{array}{l}\text { Facilities or operations which } \\
\text { handle or recycle spent } \\
\text { fluorocarbons, handle or may } \\
\text { release ozone depleting } \\
\text { substances, or store volatile } \\
\text { organic compounds }\end{array}$ & No \\
\hline & Asbestos & $\begin{array}{l}40 \text { CFR } 61, \text { Subpart M } \\
\text { BCAA Reg. 1, Article } 8\end{array}$ & $\begin{array}{l}\text { EPA } \\
\text { BCAA }\end{array}$ & $\begin{array}{l}\text { Removal, management, and } \\
\text { disposal of asbestos } \\
\text { containing materials }\end{array}$ & No \\
\hline & $\begin{array}{l}\text { Bulk Fertilizers; } \\
\text { Insecticides, Pesticides, } \\
\text { Rodenticides, } \\
\text { Fungicides, Herbicides }\end{array}$ & $\begin{array}{l}\text { WAC } 16-201 \\
\text { WAC } 16-228 \text { to }-232\end{array}$ & $\begin{array}{l}\text { State Dept. } \\
\text { of } \\
\text { Agriculture }\end{array}$ & $\begin{array}{l}\text { Bulk storage of fertilizers; } \\
\text { Use, application, storage and } \\
\text { disposal of insect, pest, and } \\
\text { vegetation control chemicals }\end{array}$ & No \\
\hline & $\begin{array}{l}\text { Underground Storage } \\
\text { Tanks }\end{array}$ & WAC 173-360 & Ecology & $\begin{array}{l}\text { Construction and operation of } \\
\text { underground tanks that store } \\
\text { oil and hazardous chemical } \\
\text { products }\end{array}$ & No \\
\hline & $\begin{array}{l}\text { Oil Spill Prevention } \\
\text { Planning and Response }\end{array}$ & $\begin{array}{l}40 \text { CFR } 112 \\
\text { WAC } 173-180 \text { A to }-181\end{array}$ & $\begin{array}{l}\text { EPA } \\
\text { Ecology }\end{array}$ & $\begin{array}{l}\text { Construction and operation of } \\
\text { facilities that store or handle } \\
\text { bulk oils near surface waters }\end{array}$ & No \\
\hline & $\begin{array}{l}\text { Pollution Prevention, } \\
\text { Waste Minimization, and } \\
\text { Community Right-to- } \\
\text { Know Notification and } \\
\text { Reporting }\end{array}$ & $\begin{array}{l}\text { DOE Order } 5400.1 \\
\text { DOE Order } 5820.2 \mathrm{~A} \\
40 \text { CFR } 355 \text { and } 372 \\
\text { WAC } 173-307\end{array}$ & $\begin{array}{l}\text { DOE } \\
\text { EPA } \\
\text { Ecology }\end{array}$ & $\begin{array}{l}\text { Facilities and operations } \\
\text { which use hazardous } \\
\text { substances, generate or } \\
\text { manage solid and hazardous } \\
\text { wastes, in excess of threshold } \\
\text { quantities }\end{array}$ & Yes \\
\hline & $\begin{array}{l}\text { Notification and } \\
\text { Remediation of } \\
\text { Environmental Releases }\end{array}$ & $\begin{array}{l}40 \text { CFR } 300 \text { and } 302 \\
\text { WAC } 173-303-145 \\
\text { WAC } 173-340\end{array}$ & $\begin{array}{l}\text { EPA } \\
\text { Ecology }\end{array}$ & $\begin{array}{l}\text { Unpermitted releases of oils } \\
\text { and hazardous substances to } \\
\text { the environment in excess of } \\
\text { threshold quantities }\end{array}$ & Yes \\
\hline
\end{tabular}


Table C-2. Estimated Levels of Effort for Environmental Actions and Tasks to Support Removal of Separable Organic from Tank 241-C-103.

\section{Estimates for the Most Likely Environmental Actions and Tasks \\ Labor Other Cost \\ Duration}

\begin{tabular}{|c|c|c|c|}
\hline National EnvironmentalPolicy & & $y=$ & $=5$ \\
\hline Review/Approve Adequacy of Existing NEPA Documentation & $40 \mathrm{~h}$ & ----- & 1 month \\
\hline State Environmental Policy A & 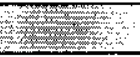 & & 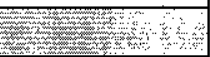 \\
\hline $\begin{array}{l}\text { Request/Document Lead Agency Concurrence with NEPA } \\
\text { Adequacy }\end{array}$ & $40 \mathrm{~h}$ & $\$ 3,000$ & 1 month \\
\hline Cultural Resources Review & tis: & 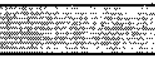 & 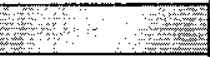 \\
\hline Confirm/Document Coverage by Cultural Resources Exemption & $6 \mathrm{~h}$ & ----- & $1 / 2$ month \\
\hline Ecological Complance Revie & 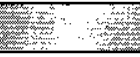 & & 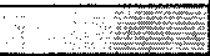 \\
\hline Confirm/Document Coverage by Blanket Biological Review & $6 \mathrm{~h}$ & ---- & $1 / 2$ month \\
\hline (Wreoperational Mouitoring of Facll & or Site & 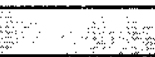 & Sy \\
\hline Prepare/Issue Documentation and Summary Report & $80 \mathrm{~h}$ & ---- & 1 month \\
\hline Hanford Site Air Operating Pel & it & +4 & $y=$ \\
\hline Request/Support Minor Modification of AOP & $60 \mathrm{~h}$ & ----- & 1 month \\
\hline Padloactive Air Emissions; Washington & te $\mathrm{QWDC}$ & 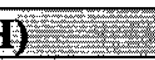 & $=2$ \\
\hline $\begin{array}{l}\text { Prepare/Submit NOC; Support WDOH Approval } \\
\text { (Short Form NOC, or Simple to Moderately Complex NOC) }\end{array}$ & $650 \mathrm{~h}$ & $\$ 2,000$ & 6 months \\
\hline Radioactive Air Emissions; Federa & F14) & & \\
\hline Prepare/Submit NOC; Support EPA Approval & $60 \mathrm{~h}$ & ----- & 1 month \\
\hline Non-Radioactive $A$ re Emissions, Washingto & tate (Bc & & 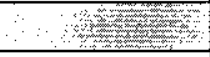 \\
\hline Prepare PSD/NSR; Request/Document Ecolo & $120 \mathrm{~h}$ & ---- & 2 months \\
\hline $\begin{array}{l}\text { Prepare/Submit NOC; Support Ecology Approval } \\
\text { (Simple to Moderately Complex NOC) }\end{array}$ & $650 \mathrm{~h}$ & $\$ 2,000$ & 8 months \\
\hline Dangerous Waste Interim St & tatus $P_{\text {E }}$ & & 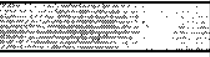 \\
\hline Request/Support Part A Interim Status Modification & $120 \mathrm{~h}$ & ----- & 4 months \\
\hline $\begin{array}{l}40 \text { CFR 265.1050, Subpart BB - "Air Emission Standards for } \\
\text { Equipment Leaks" (Includes WAP revision, Labeling \& } \\
\text { Monitoring Requirements) }\end{array}$ & & $100 \mathrm{k}$ & 10 months \\
\hline Project-/Activity-Specific Environment & Panmin & 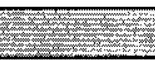 & \\
\hline Prepare Environmental Strategy and Planning Sur & $60 \mathrm{~h}$ & ----- & 1 month \\
\hline Prepare and Issue Environmental Plan & $200 \mathrm{~h}$ & $-\cdots$ & 3 months \\
\hline $\begin{array}{l}\text { Update Environmental Plan Annually (Simple to Moderately } \\
\text { Complex) }\end{array}$ & $60 \mathrm{~h}$ & ----- & 1 month \\
\hline Environmental Compliance and Readi & s suppo & & 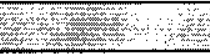 \\
\hline Provide Guidance/Issue Resolution During Conceptual Design & $5 \mathrm{~h} / \mathrm{wk}$ & $\ldots$ & 8 weeks \\
\hline Provide Guidance/Issue Resolution During Definitive Design & $5 \mathrm{~h} / \mathrm{wk}$ & ----- & 24 months \\
\hline Review Work Packages/ECNs During Construction & $5 \mathrm{~h} / \mathrm{wk}$ & ----- & 24 months \\
\hline Support Onsite Inspections During Construction & $3 \mathrm{~h} / \mathrm{wk}$ & ----- & 24 weeks \\
\hline Support Readiness Assessment/Operational Readiness Review & $3 \mathrm{~h} / \mathrm{wk}$ & 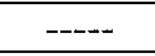 & 16 weeks \\
\hline $\begin{array}{l}\text { Provide Interpretation/Issue Resolution During Operational } \\
\text { Startup }\end{array}$ & $3 \mathrm{~h} / \mathrm{wk}$ & ----- & \\
\hline
\end{tabular}




\section{$\underline{\text { Acronyms }}$}

$\begin{array}{ll}\text { AOP } & \text { Air operating permit } \\ \text { Ecology } & \text { Washington State Department of Ecology } \\ \text { ECN } & \text { Engineering Change Notice } \\ \text { EPA } & \text { U.S. Environmental Protection Agency } \\ \text { NEPA } & \text { National Environmental Policy Act of } 1969 \\ \text { NOC } & \text { Notice of construction } \\ \text { NSR } & \text { New source review } \\ \text { PSD } & \text { Prevention of significant deterioration } \\ \text { WDOH } & \text { Washington State Department of Health }\end{array}$

Notes:

Estimates in this table are provided for initial planning purposes only. The estimates should be treated as approximations that must be further refined for detailed project- and activityspecific planning.

All labor estimates are provided in hours (h) unless indicated otherwise. Labor estimates account for all staff time, including professional and administrative.

Other costs indicate estimated expenses for significant support that may need to be purchased to accomplish the particular task (e.g., facilities, equipment, materials, printing, travel, laboratory, subcontractors).

Hourly Rate assumed to be $\$ 70.00$.

Conceptual/Definitive Design Duration assumed to be four months.

Construction Duration assumed to be six months.

Operational readiness review assumed to be one month.

Operational startup assumed to be one month. 


\section{DISTRIBUTION SHEET}

To

M.R. KOCH

Project Title/Work Order

REMOVAL OF SEPARABLE ORGANIC FROM TANK 241-C-103 SCOPING STUDY

From

D.K. DEFORD
D.G. BAIDE

V.C. BOYLES

T.I. HISSONG

J.O. HONEYMAN

H.R. HOPKINS

N.W. KIRCH

E.A. PACQUET

D.B. PARKMAN

M.A. PAYNE

J.F. RENHOLDS

S.H. RIFAEY

D.J. SAUERESSIG

D.T. VLADIMIROFF

\section{Name}

Page 1 of 1

Date $05 / 09 / 00$

EDT No. 624920

ECN No. N/A

\begin{tabular}{|c|c|c|c|c|} 
MSIN & $\begin{array}{c}\text { Text } \\
\text { With Alt } \\
\text { Attach. }\end{array}$ & Text Only & $\begin{array}{c}\text { Attach./ } \\
\text { Appendix } \\
\text { Only }\end{array}$ & $\begin{array}{c}\text { EDT/ECN } \\
\text { Only }\end{array}$ \\
\hline
\end{tabular}

- 